Prepared in cooperation with the Office of Grants Management and in collaboration with the Commonwealth Utilities Corporation, Commonwealth of the Northern Mariana Islands

\title{
Groundwater Conditions and Trends, 2009-19, Saipan, Commonwealth of the Northern Mariana Islands
}

Scientific Investigations Report $2020-5129$ 
Cover. View from Okso' Takpochao (informally known as Mount Tagpochau) looking south. This view includes the Chalan Kiya, Dan Dan, Isley Field, Koblerville, and Obyan well fields. The island of Tinian is visible in the distance. Photograph by Jackson Mitchell, August 2, 2018. 


\section{Groundwater Conditions and Trends, 2009-19, Saipan, Commonwealth of the Northern Mariana Islands}

By Jackson N. Mitchell, Todd K. Presley, and Robert L. Carruth

Prepared in cooperation with the Office of Grants Management and in collaboration with the Commonwealth Utilities Corporation, Commonwealth of the Northern Mariana Islands

Scientific Investigations Report 2020-5129 


\section{U.S. Geological Survey, Reston, Virginia: 2021}

For more information on the USGS — the Federal source for science about the Earth, its natural and living resources, natural hazards, and the environment-visit https://www.usgs.gov or call 1-888-ASK-USGS.

For an overview of USGS information products, including maps, imagery, and publications, visit https://store.usgs.gov.

Any use of trade, firm, or product names is for descriptive purposes only and does not imply endorsement by the U.S. Government.

Although this information product, for the most part, is in the public domain, it also may contain copyrighted materials as noted in the text. Permission to reproduce copyrighted items must be secured from the copyright owner.

Suggested citation:

Mitchell, J.N., Presley, T.K., and Carruth, R.L., 2021, Groundwater conditions and trends, 2009-19, Saipan, Commonwealth of the Northern Mariana Islands: U.S. Geological Survey Scientific Investigations Report 2020-5129, 51 p., https://doi.org/10.3133/sir20205129.

ISSN 2328-0328 (online) 


\section{Acknowledgments}

The Commonwealth Utilities Corporation (CUC) and the Bureau of Environmental and Coastal Quality (BECQ) generously provided most of the groundwater-withdrawal and groundwaterquality data shown in this report. The CUC also provided access to the monitor wells.

The authors thank Ed Carlson of the National Geodetic Survey for his advice and support during the differential-leveling survey of the monitor wells in March 2019.

The authors also wish to thank Heather A. Jeppesen and Delwyn S. Oki of the U.S. Geological Survey for their help with data management and project guidance, respectively. 


\section{Contents}

Acknowledgments .......................................................................................................................ii

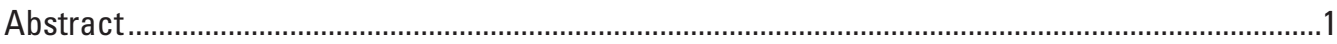

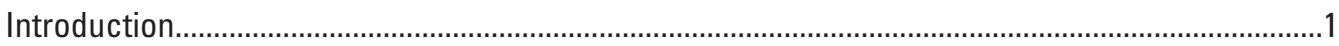

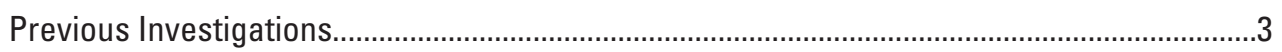

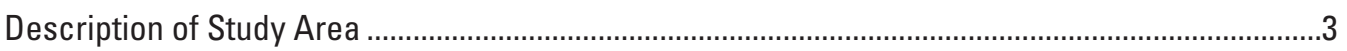

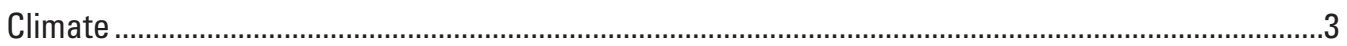

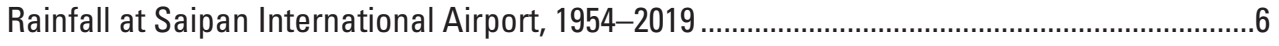

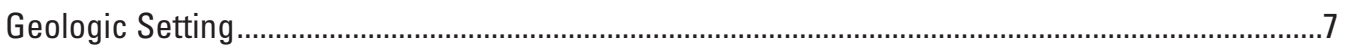

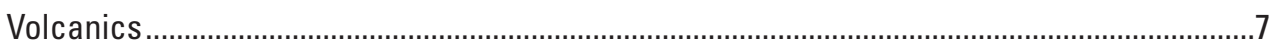

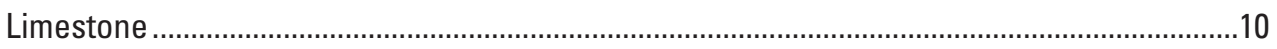

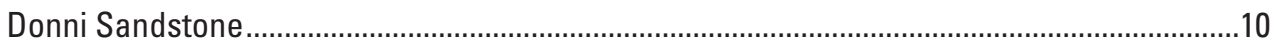

Unconsolidated Surficial Deposits ........................................................................................

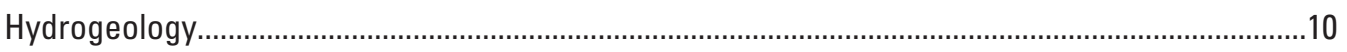

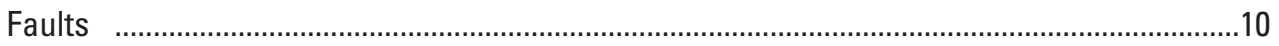

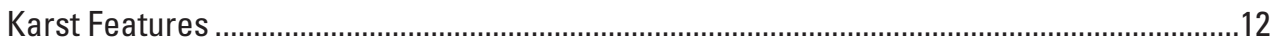

Groundwater Occurrence and Movement …………..............................................................12

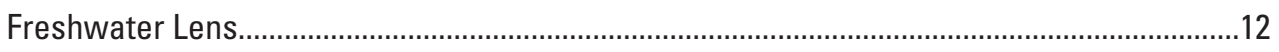

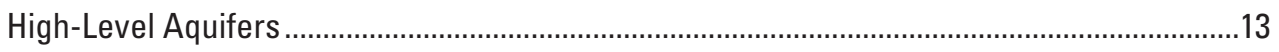

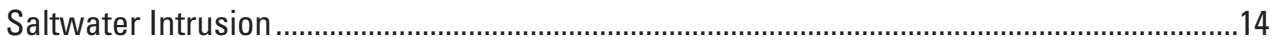

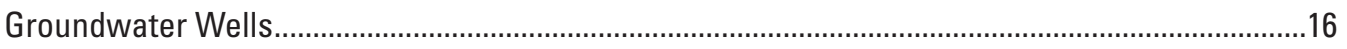

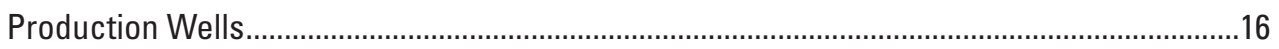

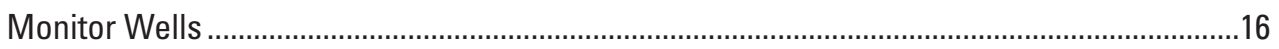

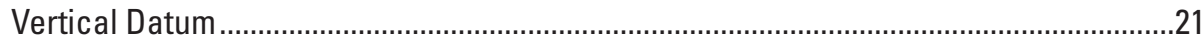

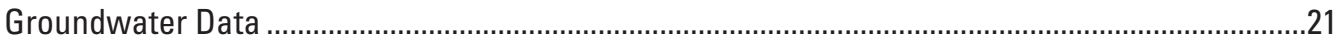

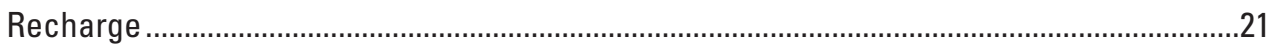

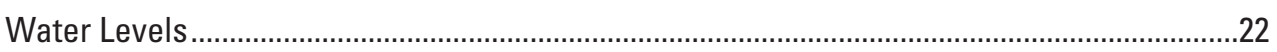

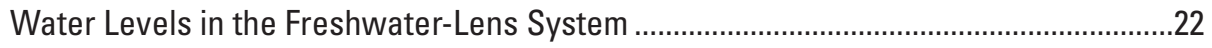

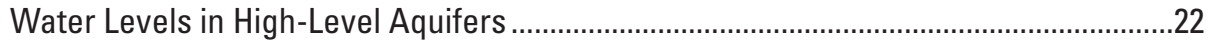

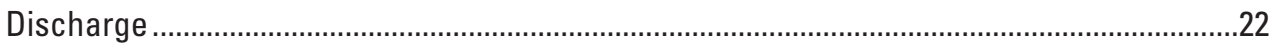

Withdrawals from Wells .....................................................................................22

Withdrawals from Municipal Production Wells, May 2014-March 2019...............24

Withdrawals from Private Production Wells.........................................................26

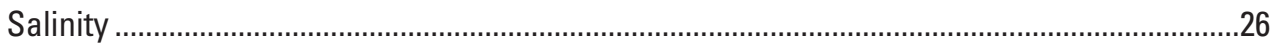

Chloride Concentrations of Groundwater Withdrawals, 2009-19 .................................26

Trends in the Chloride Concentrations of Municipal Groundwater Withdrawals, 2009-19.

Relation Between Chloride Concentration and Specific Conductance in Groundwater ......................................................................................................

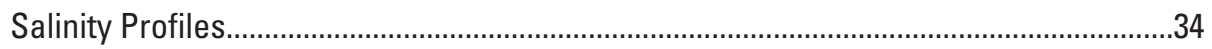

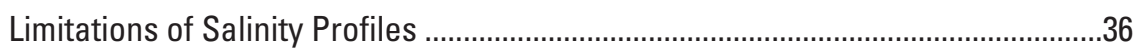

Characteristics of the Freshwater-Lens System ......................................................................

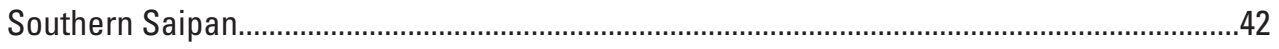

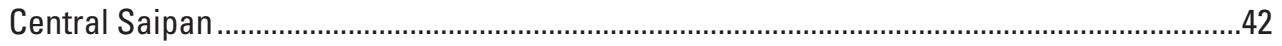


Northern Saipan. . .44

Estimated Altitudes of the Midpoint of the Transition Zone from the Ghyben-Herzberg

Principle. .44

Seasonal Variability . .44

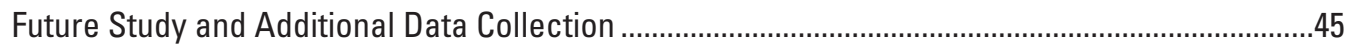

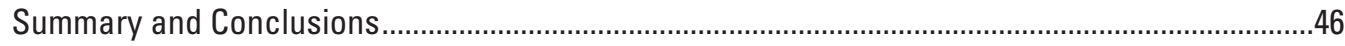

References Cited.

\section{Figures}

1. Location map, shaded relief, villages, and selected geographic features of Saipan.......2

2. Map of physiographic divisions on Saipan ...........................................................................4

3. Map of mean annual rainfall on Saipan ...............................................................................5

4. Graph of annual rainfall at Saipan International Airport, Saipan, 1954-2018....................6

5. Graph of mean monthly rainfall (1954-2018) at Saipan International Airport....................7

6. Generalized map of the surficial geology of Saipan and geologic cross sections of Saipan.......

7. Map of groundwater wells and well fields, Saipan .........................................................11

8. Schematic cross section showing groundwater occurrence, movement, and salinity structure in part of Saipan.

9. Schematics of the effects of groundwater withdrawal on the freshwater-lens system of a high-permeability island aquifer .14

10. Diagrams of general examples of saltwater upconing in a coastal aquifer ..................... 15

11. Map of municipal wells and well names, monitor wells, and well fields, Saipan ...........17

12. Graph of 7-day moving sum of daily rainfall at Saipan International Airport and graph of daily mean groundwater levels at selected monitor wells and daily mean sea level, Saipan.

13. Graph of daily mean groundwater levels at selected monitor wells, and daily rainfall at Saipan International Airport, Saipan, November-December 2002

14. Graph of monthly groundwater withdrawals from municipal wells, May 2014-April 2015 and February 2016-March 2019, Saipan

15. Graph of mean groundwater withdrawals from municipal well fields during May 2014-April 2015 and February 2016-March 2019, Saipan

16. Map of permitted groundwater-withdrawal rates for private wells, Saipan. .27

17. Boxplots summarizing the chloride concentrations of groundwater withdrawals from municipal wells in 11 selected well fields, Saipan

18. Map of median chloride concentrations for groundwater withdrawals from well fields on Saipan

19. Map of median chloride concentrations during 2009-19 and mean groundwaterwithdrawal rates during 2014-19 at municipal production wells, Saipan

20. Mapped results of Mann-Kendall test for monotonic trends in the chloride concentrations of groundwater withdrawals from municipal production wells, Saipan

21. Graph of chloride-concentration and specific-conductance data for water samples collected from municipal production wells, Saipan

22. Graph of salinity profiles in selected monitor wells on Saipan 
23. Map of freshwater-lens thickness estimates for monitor wells, median chloride concentrations at municipal production wells, mean groundwater-withdrawal rates at municipal production wells, and selected faults in southern Saipan

24. Graph of mean monthly rainfall and recorded monthly rainfall at Saipan International Airport during December 2017 to March 2019, Saipan

\section{Tables}

1. Characteristics of monitor wells, Saipan.

2. Mean volume-weighted chloride concentrations and mean groundwaterwithdrawal rates at municipal well fields, Saipan

3. Freshwater-lens and transition-zone characteristics determined from salinity profiles and water-level measurements collected in selected monitor wells, Saipan

\section{Conversion Factors}

U.S. customary units to International System of Units

\begin{tabular}{|c|c|c|}
\hline Multiply & By & To obtain \\
\hline \multicolumn{3}{|c|}{ Length } \\
\hline inch (in.) & 25.4 & millimeter $(\mathrm{mm})$ \\
\hline foot $(\mathrm{ft})$ & 0.3048 & meter $(\mathrm{m})$ \\
\hline mile (mi) & 1.609 & kilometer $(\mathrm{km})$ \\
\hline \multicolumn{3}{|c|}{ Area } \\
\hline acre & 4,047 & square meter $\left(\mathrm{m}^{2}\right)$ \\
\hline square foot $\left(\mathrm{ft}^{2}\right)$ & 0.09290 & square meter $\left(\mathrm{m}^{2}\right)$ \\
\hline square mile $\left(\mathrm{mi}^{2}\right)$ & 2.590 & square kilometer $\left(\mathrm{km}^{2}\right)$ \\
\hline \multicolumn{3}{|c|}{ Volume } \\
\hline million gallons (Mgal) & 3,785 & cubic meter $(\mathrm{m} 3)$ \\
\hline cubic foot $\left(\mathrm{ft}^{3}\right)$ & 0.02832 & cubic meter (m3) \\
\hline \multicolumn{3}{|c|}{ Flow rate } \\
\hline gallon per minute (gal/min) & 0.06309 & liter per second $(\mathrm{L} / \mathrm{s})$ \\
\hline million gallons per day $(\mathrm{Mgal} / \mathrm{d})$ & 0.04381 & cubic meter per second $\left(\mathrm{m}^{3} / \mathrm{s}\right)$ \\
\hline \multicolumn{3}{|c|}{ Pressure } \\
\hline atmosphere, standard (atm) & 101.3 & kilopascal $(\mathrm{kPa})$ \\
\hline bar & 100 & kilopascal $(\mathrm{kPa})$ \\
\hline pound per square foot $\left(\mathrm{lb} / \mathrm{ft}^{2}\right)$ & 0.04788 & kilopascal $(\mathrm{kPa})$ \\
\hline pound per square inch $\left(\mathrm{lb} / \mathrm{in}^{2}\right)$ & 6.895 & kilopascal $(\mathrm{kPa})$ \\
\hline \multicolumn{3}{|c|}{ Density } \\
\hline pound per cubic foot $\left(\mathrm{lb} / \mathrm{ft}^{3}\right)$ & 16.02 & kilogram per cubic meter $\left(\mathrm{kg} / \mathrm{m}^{3}\right)$ \\
\hline \multicolumn{3}{|c|}{ Specific capacity } \\
\hline gallon per minute per foot $([\mathrm{gal} / \mathrm{min}] / \mathrm{ft})$ & 0.2070 & liter per second per meter $([\mathrm{L} / \mathrm{s}] / \mathrm{m})$ \\
\hline \multicolumn{3}{|c|}{ Hydraulic conductivity } \\
\hline foot per day $(\mathrm{ft} / \mathrm{d})$ & 0.3048 & meter per day $(\mathrm{m} / \mathrm{d})$ \\
\hline
\end{tabular}




\section{Datum}

Vertical coordinate information is referenced to mean sea level, unless the Northern Marianas Vertical Datum of 2003 (NMVD03) is specified.

Horizontal coordinate information is referenced to the World Geodetic System of 1984 (WGS 84).

Altitude, as used in this report, refers to distance above the vertical datum.

\section{Supplemental Information}

Specific conductance is given in microsiemens per centimeter at 25 degrees Celsius $\left(\mu \mathrm{S} / \mathrm{cm}\right.$ at $\left.25^{\circ} \mathrm{C}\right)$.

Concentrations of chemical constituents in water are given in milligrams per liter (mg/L).

\section{Abbreviations}

$\begin{array}{ll}\text { BECQ } & \text { Bureau of Environmental and Coastal Quality } \\ \text { CNMI } & \text { Commonwealth of the Northern Mariana Islands } \\ \text { CUC } & \text { Commonwealth Utilities Corporation } \\ \text { EPA } & \text { U.S. Environmental Protection Agency } \\ \text { NMVD03 } & \text { Northern Marianas Vertical Datum of } 2003 \\ \text { USGS } & \text { U.S. Geological Survey }\end{array}$





\title{
Groundwater Conditions and Trends, 2009-19, Saipan, Commonwealth of the Northern Mariana Islands
}

\author{
By Jackson N. Mitchell, Todd K. Presley, and Robert L. Carruth
}

\begin{abstract}
Groundwater is the primary source of municipal water for Saipan. Nearly all groundwater for the municipal water supply is withdrawn from a freshwater-lens system with a limited amount of freshwater that is susceptible to saltwater intrusion. The status of Saipan's groundwater resources has not been thoroughly assessed since 2003. The U.S. Geological Survey - in cooperation with the Office of Grants Management, Commonwealth of the Northern Mariana Islands, and in collaboration with the Commonwealth Utilities Corporationassessed the status and characteristics of Saipan's groundwater resources by (1) evaluating groundwater withdrawals from municipal production wells during 2014-19, (2) evaluating chloride concentrations of municipal groundwater withdrawals during 2009-19, and (3) collecting salinity profiles at selected groundwater-monitoring wells during 2018-19. At the time of preparation of this report (2019), the periods of groundwaterwithdrawal and chloride-concentration data represent the only periods of data available since 2003.
\end{abstract}

During 2014-19, groundwater for the municipal water supply was withdrawn from about 143 production wells. Most of the wells are drilled into limestone formations in the southern plateau and the Kagman Peninsula and generally have withdrawal rates of about 40-60 gallons per minute. Records of monthly groundwater withdrawals from municipal production wells were available for May 2014-March 2019; during that period, monthly withdrawals ranged from 5.7 to 12.8 million gallons per day (Mgal/d) and averaged $9.3 \mathrm{Mgal} / \mathrm{d}$, although records were unavailable for 9 months (May 2015-January 2016). Private wells, mainly located on the western coastal plain, currently are permitted to withdraw a total of about $7 \mathrm{Mgal} / \mathrm{d}$ of groundwater. Actual groundwater withdrawals from private wells, however, are uncertain because withdrawal records for private wells are not available.

The Commonwealth Utilities Corporation measured the chloride concentration of groundwater pumped from each of its production wells about twice a year from 2009-19; during this period, 146 production wells were active and sampled. Only 32 of the 146 ( 22 percent) municipal production wells had median chloride concentrations less than or equal to
250 milligrams per liter (mg/L), the secondary drinking water standard set by the U.S. Environmental Protection Agency. Eighty-one wells (55 percent) pumped water with median chloride concentrations above $500 \mathrm{mg} / \mathrm{L}$.

The Mann-Kendall test was used to determine if chloride concentrations of groundwater withdrawals at 146 municipal production wells had statistically significant trends during December 2009-February 2019. Trends were considered statistically significant for probability values (p-values) less than or equal to 0.05 . Test results indicate an upward trend at 9 wells, a downward trend at 52 wells, and no trend at 85 wells.

Salinity profiles were measured in 12 selected monitor wells during July-August 2018 and were measured in six of the twelve selected monitor wells during March 2019. The salinity profiles were used to estimate the thickness of the freshwater lens at 10 monitor wells; freshwater-lens thickness was greatest (46 ft) in a monitor well in the Dan Dan well field near the northern part of the southern plateau. Freshwaterlens-thickness estimates elsewhere were (1) between 0 and $28 \mathrm{ft}$ for the remaining monitor wells on the southern plateau, (2) between 19 and $21 \mathrm{ft}$ for monitor wells on the Kagman Peninsula, (3) $2 \mathrm{ft}$ for a monitor well in the Sablan Quarry well field on west-central Saipan, and (4) $8 \mathrm{ft}$ for a monitor well in the Marpi Quarry well field on northern Saipan.

\section{Introduction}

Saipan is a tropical island in the western Pacific Ocean at lat $15^{\circ} 05^{\prime}$ to $15^{\circ} 18^{\prime}$ N., long $145^{\circ} 40^{\prime}$ to $145^{\circ} 50^{\prime}$ ' E. (fig. 1). Nearly all of Saipan's municipal water is supplied by groundwater pumped from a thin layer of freshwater, known as a freshwater lens, floating on top of saltwater because of differences in density (Davis, 1959; Van Der Brug, 1985; Carruth, 2003). The divide between freshwater and saltwater is not sharp and the two water bodies are instead separated by a transition zone in which salinity increases with depth. The thickness of the freshwater lens on Saipan ranges from a few feet in the north to a few tens of feet in the south (Carruth, 2003). The shape and size of the freshwater lens vary in response to natural and human-caused influences, including sea level, groundwater withdrawals, and groundwater 

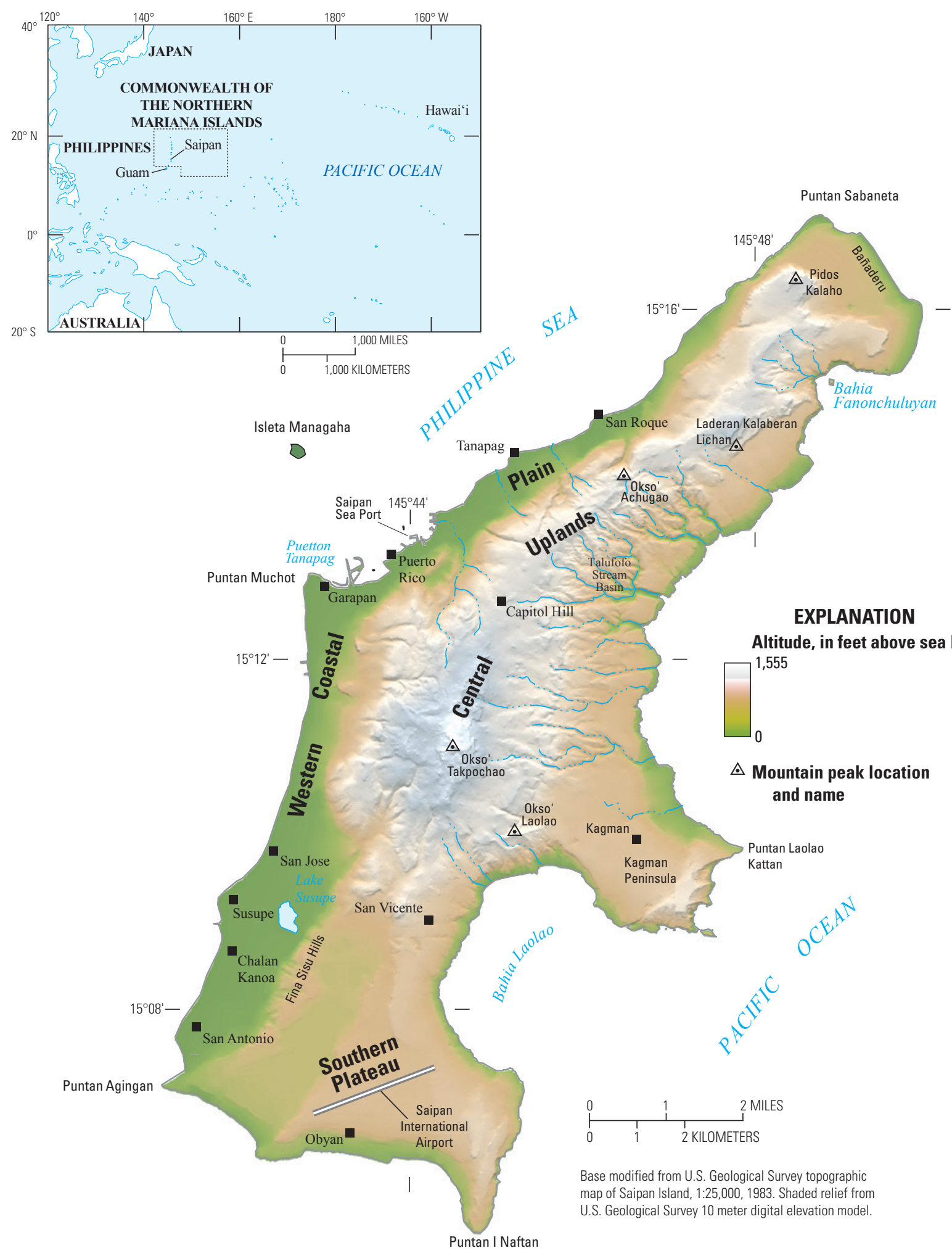

Figure 1. Location map, shaded relief, villages, and selected geographic features of Saipan (modified from Carruth, 2003). 
recharge from rainfall. Freshwater availability from the freshwater lens is limited and vulnerable because groundwater withdrawals can induce lateral and upward flow of highsalinity water below the freshwater lens. If withdrawal rates are too high or groundwater recharge is reduced because of a drought, the thickness of the freshwater lens may decrease, potentially limiting the quality of water extracted from wells.

Groundwater wells currently (2019) provide about 8-10 million gallons per day (Mgal/d) for the municipal water supply on Saipan. Most of the municipal wells currently produce water that exceeds the U.S. Environmental Protection Agency (2018) secondary drinking water standard for chloride concentration, 250 milligrams per liter ( $\mathrm{mg} / \mathrm{L})$. Secondary standards are not mandatory and represent limits that may cause aesthetic effects in drinking water, including taste, odor, or color.

The groundwater resources of Saipan have not been thoroughly assessed since 2003 (Carruth, 2003). To better understand the characteristics and status of Saipan's groundwater resources, the U.S. Geological Survey (USGS) undertook a cooperative study with the Office of Grants Management, Commonwealth of the Northern Mariana Islands (CNMI), in collaboration with the Commonwealth Utilities Corporation (CUC), to (1) collect salinity profiles at groundwater-monitoring wells, (2) summarize the hydrogeologic setting, and (3) review and summarize available groundwater-withdrawal and chloride-concentration data collected by the CUC since 2003.

This report summarizes existing descriptions of Saipan's physical setting, climate, geology, karst, faults, and groundwater resources with an emphasis on its freshwater lens. This report also summarizes groundwater data provided by the CUC, including (1) the locations and types of groundwater wells on Saipan, (2) groundwater withdrawals from municipal production wells during 2014-19, and (3) chloride-concentration values and trends for municipal production wells during 2009-19. As of 2019, the periods of groundwater-withdrawal and chloride-concentration data represent the only periods of data available since 2003. Additionally, this report describes the collection of salinity-profile measurements at 12 groundwatermonitoring wells during 2018-19 and how these measurements were used to estimate the thickness of the freshwater lens and the altitude of the midpoint of the transition zone between the freshwater lens and underlying saltwater.

\section{Previous Investigations}

Several hydrologic investigations of Saipan have been completed, consisting of both data compilations and interpretative reports. Davis (1959) assessed the available water resources and provided suggestions for water development. Van Der Brug (1985) compiled several decades of groundwater, surface-water, spring-flow, and water-quality data. Hoffmann and others (1998) described the hydrogeology of the Kagman Peninsula and estimated the hydraulic properties of the Mariana Limestone. Carruth (2000) compiled groundwater, rainfall, sea-level, and surface-water data for
1998, with an emphasis on groundwater data. Carruth (2003) completed a comprehensive investigation of groundwater resources, using groundwater data collected intermittently during 1983-2000, to characterize groundwater occurrence and availability on Saipan.

\section{Description of Study Area}

Saipan is the largest island in the CNMI, a U.S. territory that consists of the 14 main islands in the Marianas archipelago north of Guam. The island is about 14 miles (mi) long, ranges in width from 2 to $6 \mathrm{mi}$, and has an area of about $48 \mathrm{mi}^{2}$. Saipan has an estimated population of about 48,000 (CNMI Department of Commerce, 2017) and is the center of government and commerce for the CNMI. Most villages are located on the western coastal plain, the southern plateau, and the Kagman Peninsula (fig. 1). Tourism, the largest industry for Saipan, has grown steadily since 2012 and is forecast to continue growing in future years (Marianas Visitors Authority, written commun., 2019).

Six principal physiographic divisions were defined by Cloud and others (1956) to describe Saipan's geomorphology (fig. 2). Two of the physiographic divisions, the central uplands and low limestone platforms, contain most of the groundwater wells used for the municipal water supply. The most extensive division, the central uplands, spans most of the northern three-fourths of the island and includes most parts of the island that are greater than about $300 \mathrm{ft}$ above sea level. The predominant feature of the central uplands is a series of limestone terraces that encircle Okso' Takpochao (Mount Tagpochau), near the center of the island, whose peak is Saipan's highest point (1,555 ft above sea level). Most exposed volcanic rocks are located within the central uplands to the northeast of Okso' Takpochao. Additionally, groundwater withdrawn from wells within the central uplands generally has lower salinity than groundwater withdrawn from wells elsewhere on Saipan (Carruth, 2003).

The low limestone platforms include areas north and south of the central uplands, and an area east of the Donni clay hills belt and central uplands (fig. 2). Land-surface altitudes within the platforms mostly range from 120 to $240 \mathrm{ft}$ above sea level. Most of Saipan's municipal groundwater is withdrawn from wells within the low limestone platforms division, which includes the southern plateau and Kagman Peninsula.

\section{Climate}

The tropical climate of Saipan is characterized by warm temperatures with little seasonal variation, moderate to high humidity, and an estimated island-wide mean annual rainfall of about 80 in. (Lander, 2004). At Saipan International Airport, located on the southern plateau (fig. 1), minimum and maximum temperatures during 2006-18 were 69 and $101^{\circ} \mathrm{F}$, respectively (National Oceanic and Atmospheric Administration, 2019). Saipan's dry season spans December through June 


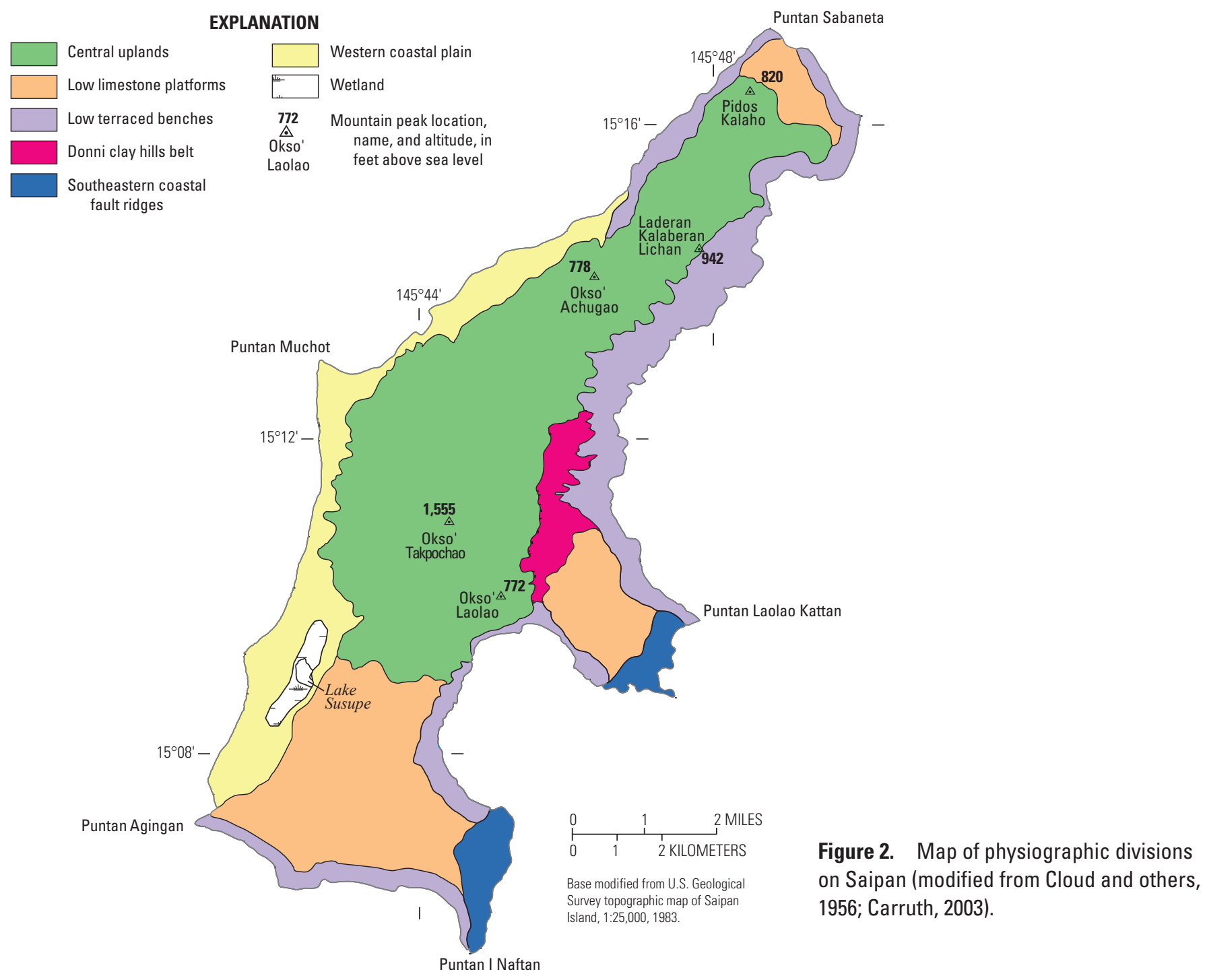

and its wet season spans July through November (Hoffmann and others, 1998; National Oceanic and Atmospheric Administration, 2019). Trade winds from the east and northeast prevail for most of the year but occasionally can be replaced by west and southwest winds during the wet season (Lander, 2004). Rainfall during the dry season occurs irregularly and daily totals rarely exceed 0.25 in. (Lander, 2004). Much of the wetseason rainfall comes from individual convective clouds that produce heavy downpours.

Saipan is in the western North Pacific basin (the sea area from $100^{\circ}$ to $180^{\circ} \mathrm{E}$ in the northern hemisphere), the most active tropical cyclone basin in the world (Yumoto and Matsuura, 2001). Tropical cyclones from the western North Pacific, known locally as typhoons, generally move west or northwest toward the Philippines or Japan (Liu and Chan, 2008). Typhoons in the western North Pacific are most common during late summer to autumn but can occur any month of the year (Lander, 2004). Typhoons that make landfall or pass near Saipan can bring high winds and heavy rainfall. Although rainfall amounts generated by typhoons are variable, typhoons are responsible for most of the high-intensity rainfall on Saipan and can contribute a large part of the annual rainfall during active typhoon years (Lander, 2004).

One of the primary drivers behind interannual climate variability on Saipan is the El Niño-Southern Oscillation (ENSO) (Lander, 2004), which characterizes the combined effects of sea-surface-temperature and atmospheric-pressure anomalies in the Pacific basin (Trenberth, 1997). ENSO patterns generally recur on the time scale of a few to several years and can have wide-ranging effects on rainfall, surface temperatures, and global-circulation patterns (Trenberth and Hurrell, 1994; Kestin and others, 1998; Kim and others, 2003). The atmospheric component of ENSO is commonly quantified by the Southern Oscillation Index (SOI), which is a metric of air-pressure differences between Tahiti and Darwin, Australia (see for example Trenberth, 1984). Negative SOI values represent low air pressures at Tahiti relative to Darwin and positive SOI values represent high air pressures at Tahiti relative to Darwin (Ropelewski and Jones, 1987). The ENSO cycle is divided into three phases: El Niño, La Niña, and neutral. El 
Niño phases correspond to positive anomalies in sea-surface temperature in the eastern Pacific and negative anomalies in the SOI. Conversely, La Niña phases correspond to negative anomalies in sea-surface temperature in the eastern Pacific and positive anomalies in the SOI. Neutral phases represent periods during which neither El Niño nor La Niña phases are active. Saipan is in a region of the Pacific Ocean that generally receives below-average rainfall during El Niño phases of ENSO (Ropelewski and Halpert, 1987). Lander (2004) suggested the driest years on Saipan generally follow a strong El Niño by one year, although the strength of this relation is less clear during some years because of the input of typhoongenerated rainfall.
The spatial distribution of mean annual rainfall on Saipan is not known with certainty, owing to incomplete rainfall records for different parts of the island. However, Lander (2004) estimated that the spatial distribution of mean annual rainfall on Saipan varies by as much as 22 in., although the periods used to determine mean annual rainfall values at rainfall-gaging stations were inconsistent (fig. 3). Minimum mean annual rainfall, about $73 \mathrm{in}$., occurs on the southern plateau; maximum mean annual rainfall, about 96 in., occurs near Capitol Hill in the center of the island. The spatial variability of mean annual rainfall can be attributed to a moderate orographic effect, whereby moist air ascends topographic high points, cools, and condenses to create rainfall (Lander, 2004).
Figure 3. Map of mean annual rainfall on Saipan, Commonwealth of the Northern Mariana Islands (modified from Lander, 2004; Perrault, 2007). The mean annual rainfall value for Saipan International Airport was determined for 1954-2018; annual rainfall values during 1954-99 were derived from Lander (2004) and annual rainfall values during 2000-18 were from the National Oceanic and Atmospheric Administration (2019). Mean annual rainfall values for the remaining rainfall-gaging stations were computed from inconsistent periods by Lander (2004). For more information about the mean annual rainfall values, see Lander (2004).

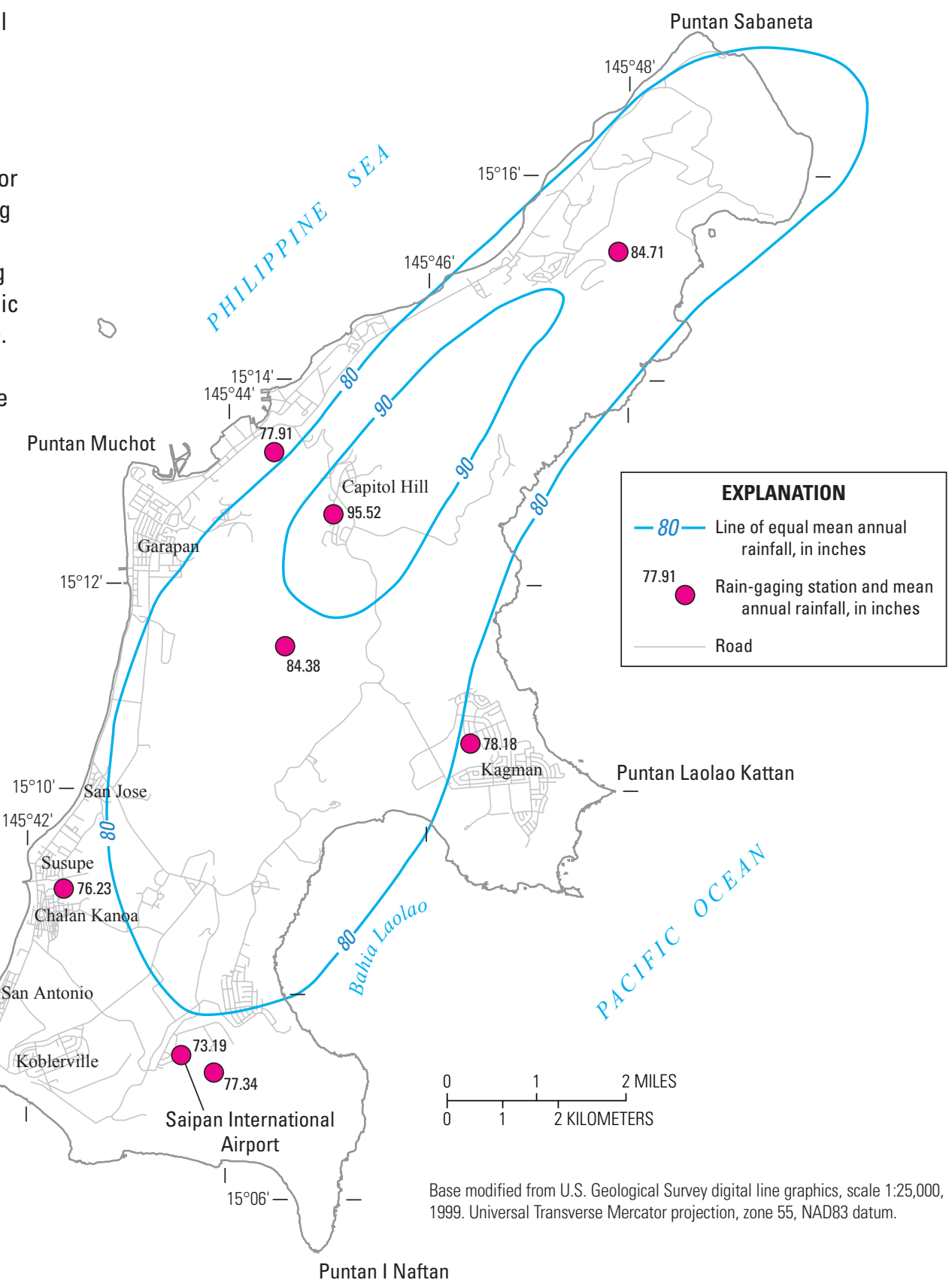


Rainfall at Saipan International Airport, 19542019

The most complete rainfall record on Saipan is from measurements at Saipan International Airport (fig. 3). For this report, one set of monthly rainfall values for Saipan International Airport for 1954-2019 was compiled from two datasets. Monthly rainfall values for 1954-99 were obtained from Lander (2004) and monthly rainfall values for 2000-19 were computed from daily rainfall values obtained from the National Centers for Environmental Information (National
Atmospheric and Oceanic Administration, 2019). March 2019 was the last month of rainfall data included in this report.

Rainfall data from 2019 were not included in the computation of mean annual and mean monthly rainfall values. During 2000-18, 8 months had incomplete rainfall data; values for these months were replaced with the corresponding mean monthly rainfall value computed from months with complete records during 1954-2018.

During 1954-2018, mean annual rainfall at Saipan International Airport was about 73.2 in. (figs. 3, 4). Mean rainfall during the dry season (December to June) was about

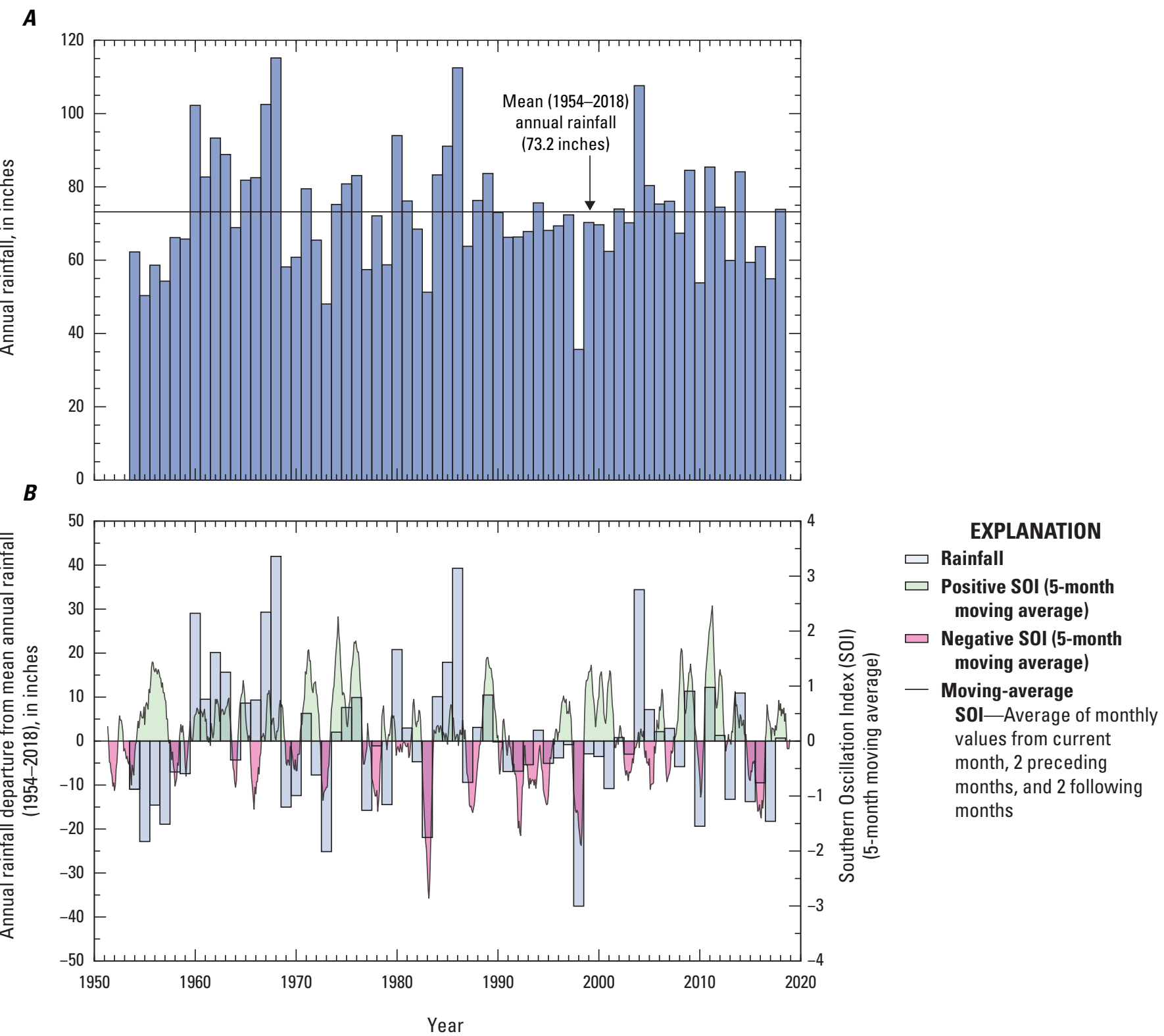

Figure 4. A, Graph of annual rainfall at Saipan International Airport, Saipan, Commonwealth of the Northern Mariana Islands, 1954-2018. B, Graph of annual rainfall departures from mean annual rainfall (1954-2018) at Saipan International Airport, and a 5-month moving average of monthly Southern Oscillation Index (SOI) values during 1951-2018. Annual rainfall values during 1954-99 were derived from Lander (2004); annual rainfall values during 2000-18 and monthly SOI values during 1951-2018 from the National Oceanic and Atmospheric Administration (2019). 
$24.7 \mathrm{in}$. and mean rainfall during the wet season (July to November) was about 48.5 in. (fig. 5). The driest year, 1998, received about 36 in. of rain; the wettest year, 1968, received about 115 in. of rain (fig. $4 A$ ). Years with below-average rainfall commonly are associated with low SOI values, corresponding to El Niño events (Lander, 2004) (fig. 4B). Mean annual rainfall at Saipan International Airport during 2009-18 was about 69.4 in., or about 5 percent below the mean (73.2 in.) during 1954-2018.

\section{Geologic Setting}

The following discussions on geology are primarily extracted from Cloud and others (1956), Carruth (2003), and Weary and Burton (2011). Saipan is composed of a volcanic core surrounded by a series of limestone terraces that extend from the center of the island to the coast and offshore. The volcanic rocks of the core were created by volcanic eruptions during the evolution of the Izu-Bonin-Mariana arc system (Karig, 1971; Stern and others, 2003). Volcanism on Saipan produced primarily dacitic and andesitic rocks, some of which have been eroded and reworked to form breccias, conglomerates, and sandstones. The marine limestones that cover most of the volcanic core comprise about 20 gently sloping terraces that formed during intermittent changes in relative sea level owing to uplift, subsidence, and changes in the volume of ocean water (Cloud and others, 1956). Holocene and Pleistocene surficial deposits overlap the limestones on the edges of the island and are found primarily on the western coastal plain. A geologic map and geologic cross sections from Carruth (2003) and Weary and Burton (2011) are shown in figure 6 and contain stratigraphic revisions from the work of Cloud and others (1956).

\section{Volcanics}

The volcanic formations of Saipan consist of the Sankakuyama, Hagman, Densinyama, and Fina-Sisu Formations (Cloud and others, 1956; Weary and Burton, 2011) (fig. 6). The dacitic to rhyolitic flow and pyroclastic rocks of the Sankakuyama Formation are the oldest exposed rocks and underlie all other exposed rock units. Radiometric dating of two samples of Sankakuyama dacite indicate an age of about 45 million years $(\mathrm{Ma})$, corresponding to the late Eocene (Cosca and others, 1998; Reagan and others, 2008). The Sankakuyama Formation is estimated to be at least $1,800 \mathrm{ft}$ thick, based on a section of exposed rocks along the flanks of Okso' Achugao (Mount Achugao) (fig. 2). Okso' Achugao is interpreted by Cloud and others (1956) to be a remnant of a stratified composite volcanic cone centered not far north of the present peak.

Two other volcanic formations are exposed near Okso' Achugao: the andesitic pyroclastic rocks, lava flows, and volcanogenic sediments of the Hagman Formation; and the marine transitional rocks, volcanogenic sediments, and andesitic breccia of the Densinyama Formation. The Hagman Formation also is exposed along the flanks of Okso' Laolao (Mount Laolao) and on the eastern side of the Laolao Bay fault near the coast at Puntan I Naftan (I Naftan Point) and Kagman Peninsula. The younger Densinyama Formation overlies the Hagman Formation. Both formations have conflicting ages determined from biostratigraphic and radiometric dating, ranging from the Eocene to the Oligocene (Weary and Burton, 2011).

Weathered outcrops of the Fina-Sisu Formation, made up of calcareous marine tuffs and andesite flows, are exposed in southern Saipan. Todd and others (1954) reported a late Oligocene age for the Fina-Sisu Formation based on microfossils; however, potassium-argon analysis produced an age of about $12 \mathrm{Ma}$, corresponding to the middle Miocene (Meijer and others, 1983). More recent biostratigraphic ages range from the Miocene to the Pliocene (Weary and Burton, 2011). Contrary to Cloud and others (1956), Weary and Burton (2011) concluded that the Fina-Sisu lies above the Tagpochau Limestone. Generally, the surfaces of the iron- and aluminarich andesitic rocks and sediments have been intensely weathered and altered to clay, soft saprolites, and acidic soils. The surfaces of the quartz-rich dacitic rocks, however, appear almost unweathered.

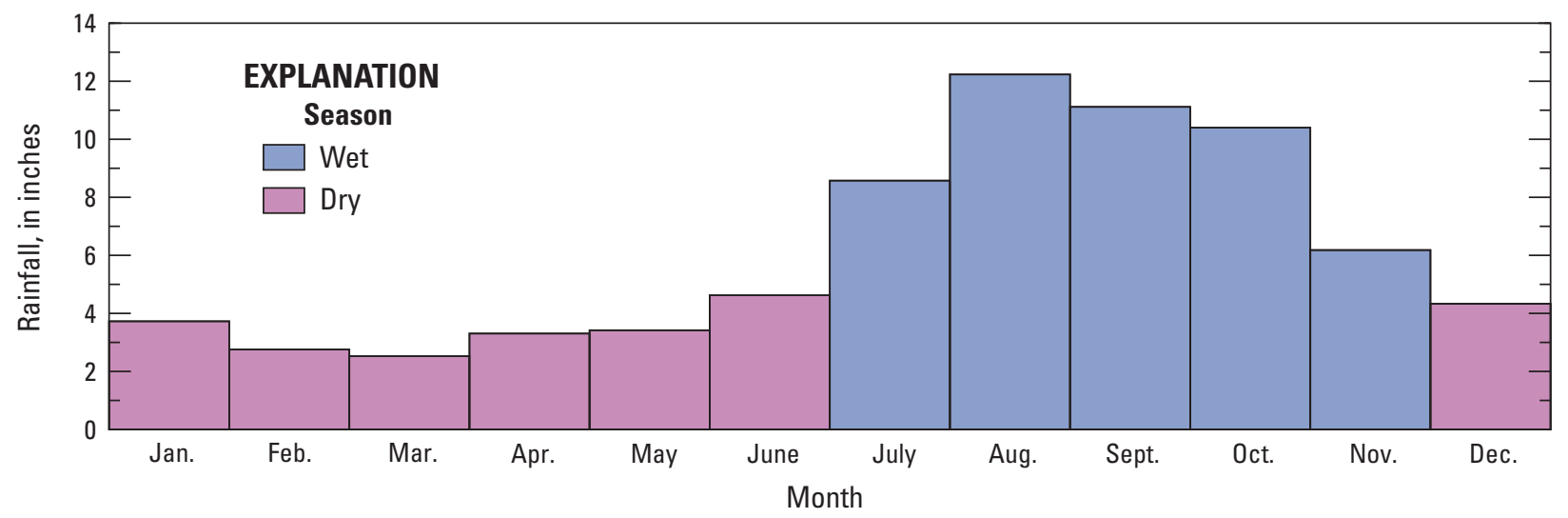

Figure 5. Graph of mean monthly rainfall (1954-2018) at Saipan International Airport, Saipan, Commonwealth of the Northern Mariana Islands. Data for 1954-99 from Lander (2004) and data for 2000-18 from the National Oceanic and Atmospheric Administration (2019). 


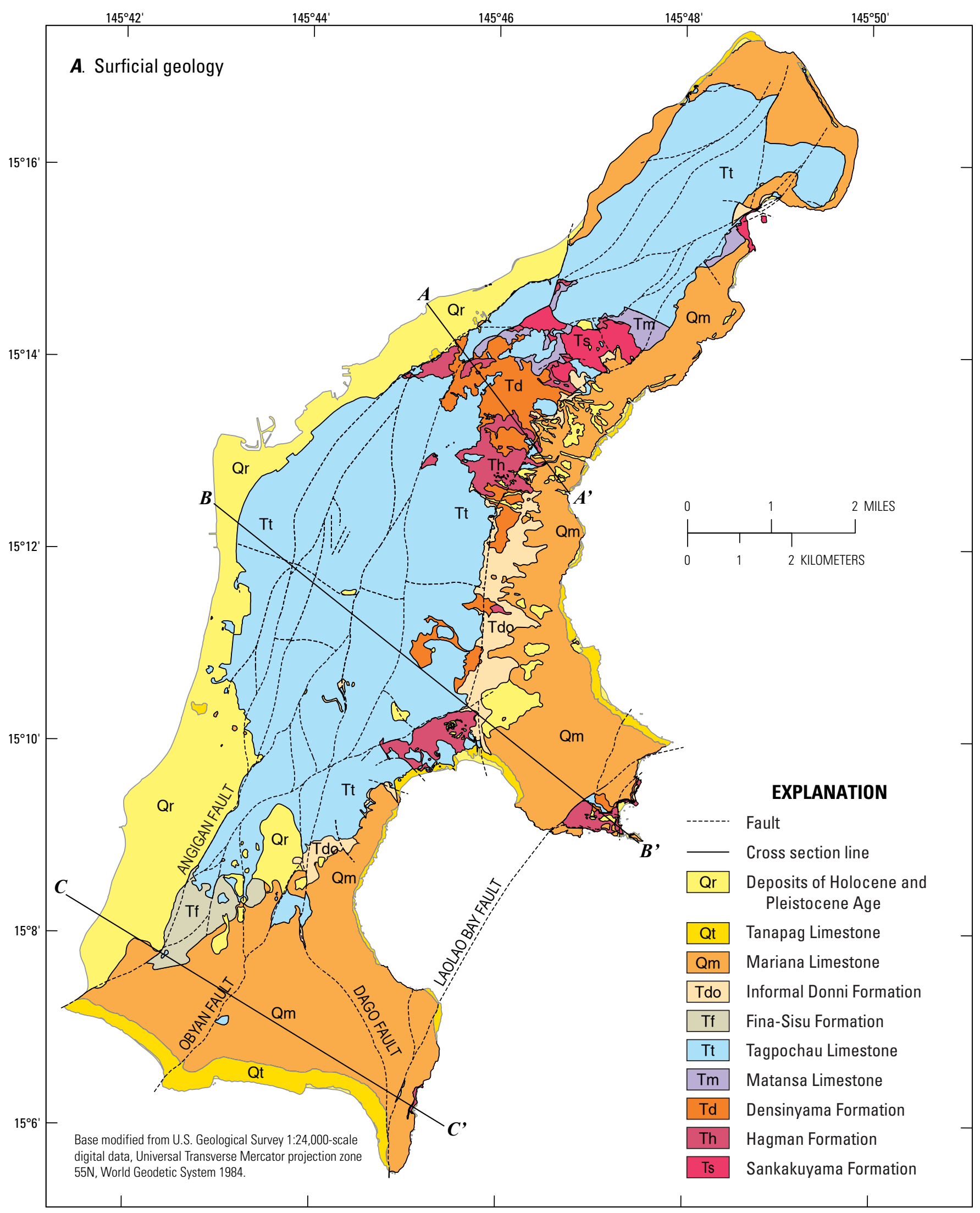

Figure 6 (pages 8-9). A, Generalized map of the surficial geology of Saipan, Commonwealth of the Northern Mariana Islands. $B$, Geologic cross sections of Saipan, Commonwealth of the Northern Mariana Islands. Surficial geology was modified from Weary and Burton (2011). Geologic cross sections $A-A^{\prime}$ and $B-B^{\prime}$ were modified from Weary and Burton (2011) and $C-C^{\prime}$ was modified from Carruth (2003). Question marks (?) in the cross sections indicate that the boundary or formation is uncertain. 


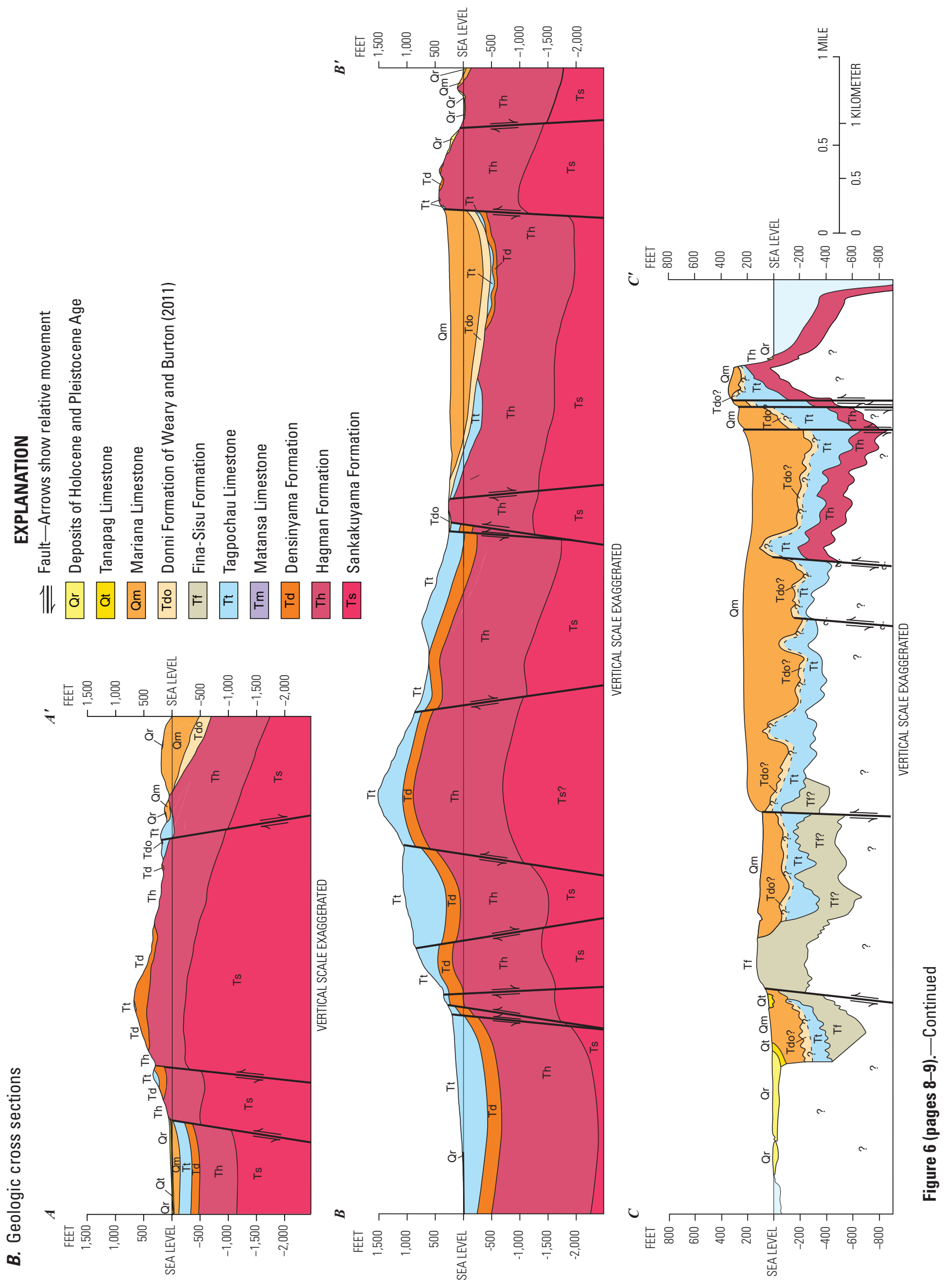




\section{Limestone}

The limestone formations of Saipan consist of the Matansa, Tagpochau, Mariana, and Tanapag Formations (Cloud and others, 1956; Weary and Burton, 2011) (fig. 6). The Matansa Limestone has been tentatively assigned as Eocene by Weary and Burton (2011). The exposed rock consists of a pure white limestone facies, impure pink facies, and argillaceous transitional facies. The Matansa Limestone is well indurated, and the limited outcrops are found in northern Saipan.

The Tagpochau Limestone of the early Miocene consists of varied facies that are mostly carbonates with small amounts of clastic rocks. The Tagpochau Limestone covers most of the central uplands and has an estimated maximum thickness of about $900 \mathrm{ft}$ (Cloud and others, 1956).

The Mariana Limestone, of Pliocene and Pleistocene age, is a fragmented and coarsely porous limestone with a coralline and algal composition and is moderately argillaceous. The unit mainly crops out on the southern plateau and the eastern coast and has an estimated maximum thickness of about $500 \mathrm{ft}$ (Cloud and others, 1956).

The Tanapag Limestone of the late Pleistocene is a coarsely porous, fringing-reef limestone composed of corals and coralline algae and has a dirty-white to brown color. The unit has an estimated maximum thickness of about $50 \mathrm{ft}$ and generally is restricted to altitudes below $100 \mathrm{ft}$ above sea level near the south and east coasts of the island (Cloud and others, 1956).

\section{Donni Sandstone (Donni Formation of Weary and Burton [2011])}

The Donni Sandstone, described as a member of the Tagpochau Limestone by Cloud and others (1956), was reclassified by Weary and Burton (2011) as a separate formation, the informal Donni formation, after concluding that the Donni Sandstone was younger and stratigraphically higher than was previously reported. The Donni Sandstone, hereinafter referred to as the "Donni formation of Weary and Burton (2011)," contains conglomerate, sandstone, and transitional facies. The Donni formation of Weary and Burton (2011) overlies the Tagpochau Limestone and the two units are separated by an angular conformity. Weary and Burton (2011) interpreted the Donni formation of Weary and Burton (2011) as being of Miocene to Pliocene age.

\section{Unconsolidated Surficial Deposits}

Unconsolidated surficial deposits from the Holocene and Pleistocene cover much of Saipan's western coastal plain, in addition to a few limited outcrops on the perimeter and the south- and east-central parts of the island (fig. 6). The deposits include younger terrace deposits, alluvium and clay wash, gravels of reworked volcanic materials, emerged lime sand, and marsh and lake deposits (Cloud and others, 1956). The estimated maximum thickness of the surficial deposits is 20-30 ft (Cloud and others, 1956).

\section{Hydrogeology}

In general, Saipan's four geologic groups (volcanic formations, limestone formations, the Donni formation of Weary and Burton [2011], and unconsolidated surficial deposits) have different permeabilities - permeability describes the relative ease with which fluid can flow through the rock. The volcanic rocks and the Donni formation of Weary and Burton (2011) generally have low permeabilities, impede the movement of groundwater, and are considered confining units (Hoffmann and others, 1998; Carruth, 2003). The limestone formations generally have high regional permeabilities; however, local permeabilities may be variable owing to geologic heterogeneity. About half of Saipan's municipal production wells have well bottoms that penetrate the Mariana Limestone (Carruth, 2003) (fig. 7). The unconsolidated surficial deposits generally have moderate to high permeabilities (Van Der Brug, 1985). Limestone covers about 73 percent of Saipan's surface; volcanically derived rocks and the Donni formation of Weary and Burton (2011) cover about 11 percent; and unconsolidated surficial deposits cover about 16 percent (Weary and Burton, 2011).

\section{Faults}

The principal tectonic features on Saipan are normal faults that trend northeast (fig. $6 \mathrm{~A}$ ), approximately parallel to the island's long axis and to the trend of the Mariana archipelago. Faulting on Saipan has resulted in vertical displacements of as much as $100 \mathrm{ft}$ (Cloud and others, 1956) and has introduced complexity into the sequence and permeabilities of the rocks. In some places, surface exposures of the faulted limestone show weathered gaps along the fault, suggesting that some faults may represent narrow zones of higher permeability relative to the surrounding rock (Carruth, 2003). In other places, test drilling near fault zones in limestone has penetrated dense, hard, and compact rock, suggesting that compression of the rock near the fault zone may create zones of lower permeability relative to that of the surrounding rock (Carruth, 2003).

Within Saipan's southern plateau, four notable faults have displacements downward to the west. Two of the faults, the Obyan and Dago faults, may affect groundwater levels and flow in the area. The Obyan fault trends northeast from the middle of the southern coast and separates the Koblerville well field from the Isley Field and Obyan well fields (fig. 7). Groundwater levels west of the Obyan fault generally are about $0.5-1 \mathrm{ft}$ lower than groundwater levels east of the fault, indicating that the Obyan fault may act as a hydrologic barrier (Nance, 1983). The Dago fault trends northwest from near Puntan I Naftan and intersects obliquely with the Obyan fault near the Dan Dan well field. Continuous groundwater-level data from wells indicate no notable tidal variations in groundwater levels west of the Dago fault and measurable tidal variations east of the fault, indicating that the Dago fault may act as a hydrologic barrier (J.P. Hoffmann, U.S. Geological Survey, written commun., 1993). 


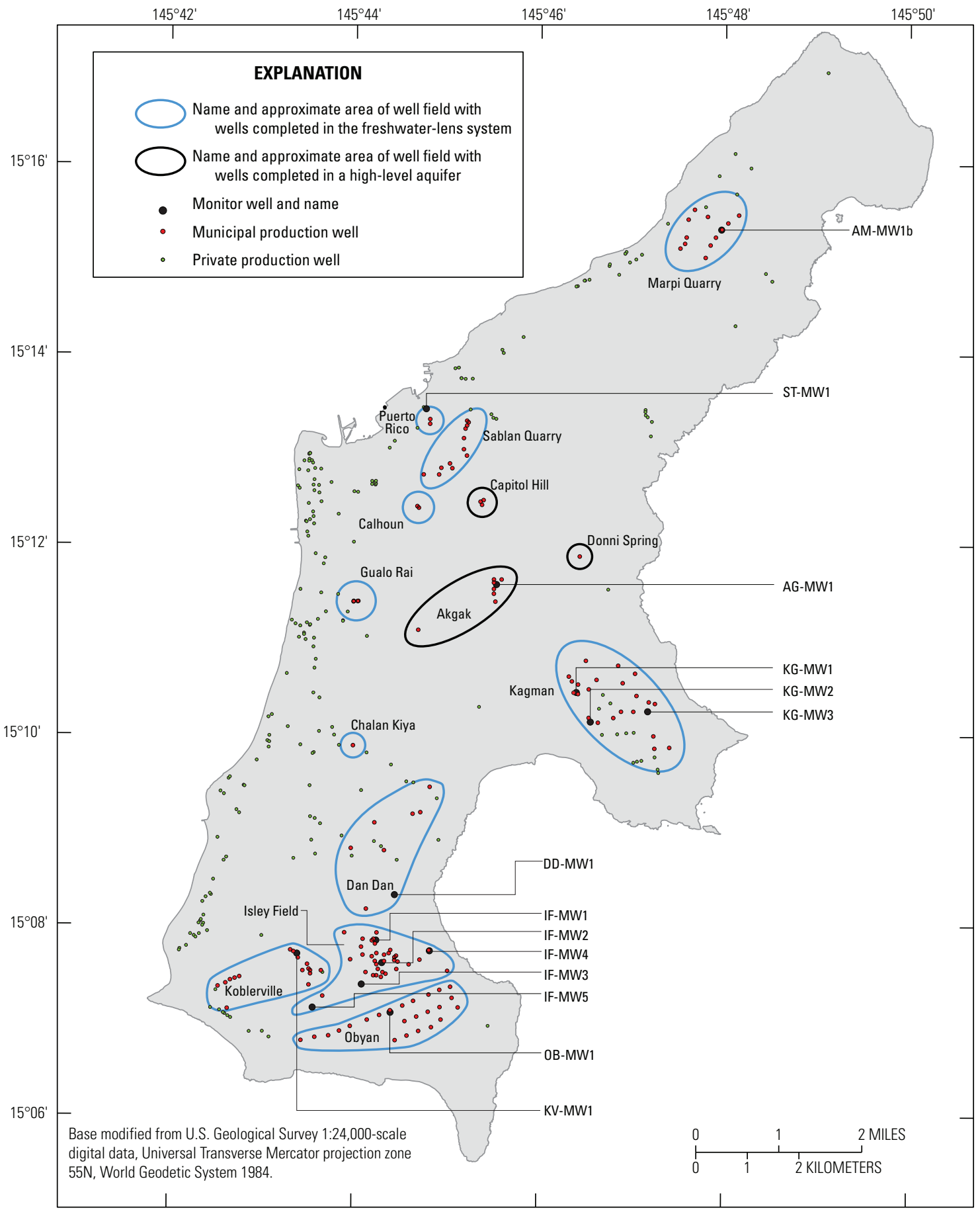

Figure 7. Map of groundwater wells and well fields, Saipan, Commonwealth of the Northern Mariana Islands. Monitor- and municipal-well locations are from Carruth (2003) and the Commonwealth Utilities Corporation; private-well locations are from the Bureau of Environmental and Coastal Quality (at the time of publication, the data had not been published by the Commonwealth Utilities Corporation or the Bureau of Environmental and Coastal Quality). 


\section{Karst Features}

Dissolution of limestone from rainfall and groundwater can create karst features in the surface and subsurface, such as closed depressions and caves (Dreybrodt, 1990; Mylroie and others, 2001). Dissolution can occur in the rock matrix, in fractures, or along preexisting conduits, and often results in the formation of preferential-flow pathways through which water can rapidly move in both the unsaturated and saturated zones (Jocson and others, 2002; Maloszewski and others, 2002; White, 2002). The effects of karst features on groundwater occurrence, movement, and availability have not been directly investigated on Saipan. In karst landscapes similar to Saipan (for example, northern Guam), heavy rainfall may reach the water table within a few hours, even in areas where the unsaturated-zone thickness exceeds $100 \mathrm{ft}$ (Mylroie and others, 1999).

The transition zone of brackish groundwater that separates a freshwater lens from saltwater in coastal limestone aquifers also is a zone of enhanced chemical reactivity, leading to increased limestone dissolution (Fratesi, 2013). Past eustatic and tectonic sea-level changes that affected Saipan shifted the transition zone up and down and would have created a distinct layer of increased limestone dissolution for each prolonged sea-level stand (see for example Mylroie and Carew, 1990, and Mylroie and Mylroie, 2007). Furthermore, Vacher and Mylroie (2002) indicated that karst development within the saturated zone of young limestones, like those on Saipan, would decrease vertical permeability while increasing the horizontal permeability of the limestones.

A comprehensive inventory of Saipan's karst features is not known to exist. Several of Saipan's caves, however, are described in Cloud and others (1956) and Jenson and others (2006), with some caves described as having heights greater than $150 \mathrm{ft}$ and lengths greater than 1,000 ft.

\section{Groundwater Occurrence and Movement}

The occurrence and movement of Saipan's groundwater is described by Van Der Brug (1985), Hoffmann and others (1998), and Carruth (2003). Most of the developed fresh groundwater on Saipan is from limestone formations. Where the base of the limestone is considerably below sea level, fresh groundwater forms a thin lens-shaped body that floats atop the underlying saltwater and is known as a freshwater lens (fig. 8). Where the base of the limestone is above sea level, principally in the central area of the island, small amounts of fresh groundwater accumulate in high-level aquifers. Highlevel aquifers exist because flow is impeded by low-permeability volcanic rocks that compartmentalize and underlie the limestone. The volcanic rocks that form the core of the island may contain large quantities of fresh groundwater; however, because of their low permeabilities, the volcanic rocks are poor water-bearing materials. Groundwater also can discharge as springs in areas where the land surface intersects flowing groundwater.

\section{Freshwater Lens}

A freshwater lens forms because of density differences between freshwater, derived from rainfall, and the underlying saltwater, derived from the ocean. On small oceanic islands, such as Saipan, the freshwater lens generally is thickest toward the center of the island and thinnest near the coast. Freshwater and the underlying saltwater are separated by brackish water in a transition zone in which salinity increases with depth. The transition zone develops from the mixing of freshwater and saltwater in response to saltwater circulation, semidiurnal ocean-tide fluctuations, and variations in recharge, discharge, and barometric pressure (Wentworth, 1942; Cooper, 1959; Underwood and others, 1992). The freshwater lens, brackishwater transition zone, and underlying saltwater are all part of the freshwater-lens system. Most of Saipan's municipal water supply comes from groundwater withdrawn from the freshwater-lens system.

Groundwater within a freshwater lens generally moves from inland recharge areas to coastal discharge areas, where discrete springs and diffuse seepage exist above and below sea level (fig. 8). Freshwater generally flows horizontally but may have a downward component in recharge areas and an upward component in discharge areas (Izuka and Gingerich, 1998). Beneath the freshwater lens, saltwater flows inland and upward until it mixes with freshwater, forming the transition zone. The brackish water within the transition zone flows toward the coast and is replaced by saltwater that mixes with freshwater to form additional brackish water, creating a circulation of saltwater within the freshwater-lens system (Barlow, 2003).

The thickness of an island's freshwater lens can be estimated using the Ghyben-Herzberg principle, which states that every foot of freshwater above sea level is balanced by $40 \mathrm{ft}$ of freshwater below sea level (Badon Ghyben, 1889; Herzberg, 1901). For example, at a location where the water table is $2 \mathrm{ft}$ above sea level, the Ghyben-Herzberg principle indicates that an additional $80 \mathrm{ft}$ of freshwater is present below sea level, resulting in a freshwater-lens thickness of $82 \mathrm{ft}$. The 1:40 ratio is predicted because saltwater is about one-fortieth (2.5 percent) denser than freshwater. The principle assumes that freshwater flow is horizontal, and that freshwater and saltwater do not mix. Because freshwater and saltwater are separated by a brackish transition zone instead of a sharp interface, however, the Ghyben-Herzberg principle is more commonly used to estimate the depth where salinity is about 50 percent that of saltwater, known as the midpoint of the transition zone (fig. 8).

The thickness of the freshwater lens depends on both natural and anthropogenic factors. The freshwater lens on a small island generally is assumed to thicken with increasing distance from the coast, increasing recharge, decreasing 
groundwater withdrawals, and decreasing rock permeability (Budd and Vacher, 1991; Schneider and Kruse, 2003). The variations in freshwater-lens thickness on Saipan, however, are complicated because rock permeability in karst aquifers is highly scale-dependent (Teutsch and Sauter, 1991; Whitaker and Smart, 2000). Regionally, the high permeabilities of the limestone formations on Saipan lead to freshwater-lens thicknesses that vary from a few feet in the north of the island to a few tens of feet in the south of the island (Carruth, 2003). Locally, the spatial distribution of permeability is more complex because of faulting and karst development in the saturated zone. The karst network of voids and conduits through which groundwater preferentially flows may result in substantial differences in permeability across short distances (Mylroie and Vacher, 1999; White, 2002). In such cases, local variations in groundwater levels and freshwater-lens thicknesses may not be adequately characterized by data collected from a sparse network of wells (Bakalowicz, 2005).

Most of the groundwater in Saipan's freshwater-lens system is in unconfined aquifers, although confined conditions exist on the west side of the Kagman Peninsula (Van Der Brug,
1985). Here, groundwater in the Tagpochau Limestone is sometimes confined by the low-permeability Donni formation of Weary and Burton (2011) (Hoffmann and others, 1998). The geologic reinterpretation by Weary and Burton (2011), whereby the Donni formation of Weary and Burton (2011) is always found stratigraphically above the Tagpochau Limestone unless eroded away, suggests that freshwater may also be confined in the Tagpochau Limestone in other areas if the Donni formation of Weary and Burton (2011) is present. Groundwater in confined aquifers on Saipan typically has lower salinity than groundwater in nearby unconfined aquifers because the low permeability confining units impede the seaward flow of freshwater and allow freshwater to build up above and below sea level (Van Der Brug, 1985; Hoffmann and others, 1998).

\section{High-Level Aquifers}

The central uplands of Saipan contain small amounts of water in high-level limestone aquifers, which are underlain and laterally contained by low-permeability volcanic rocks (Carruth, 2003) (fig. 8). The low chloride concentrations of

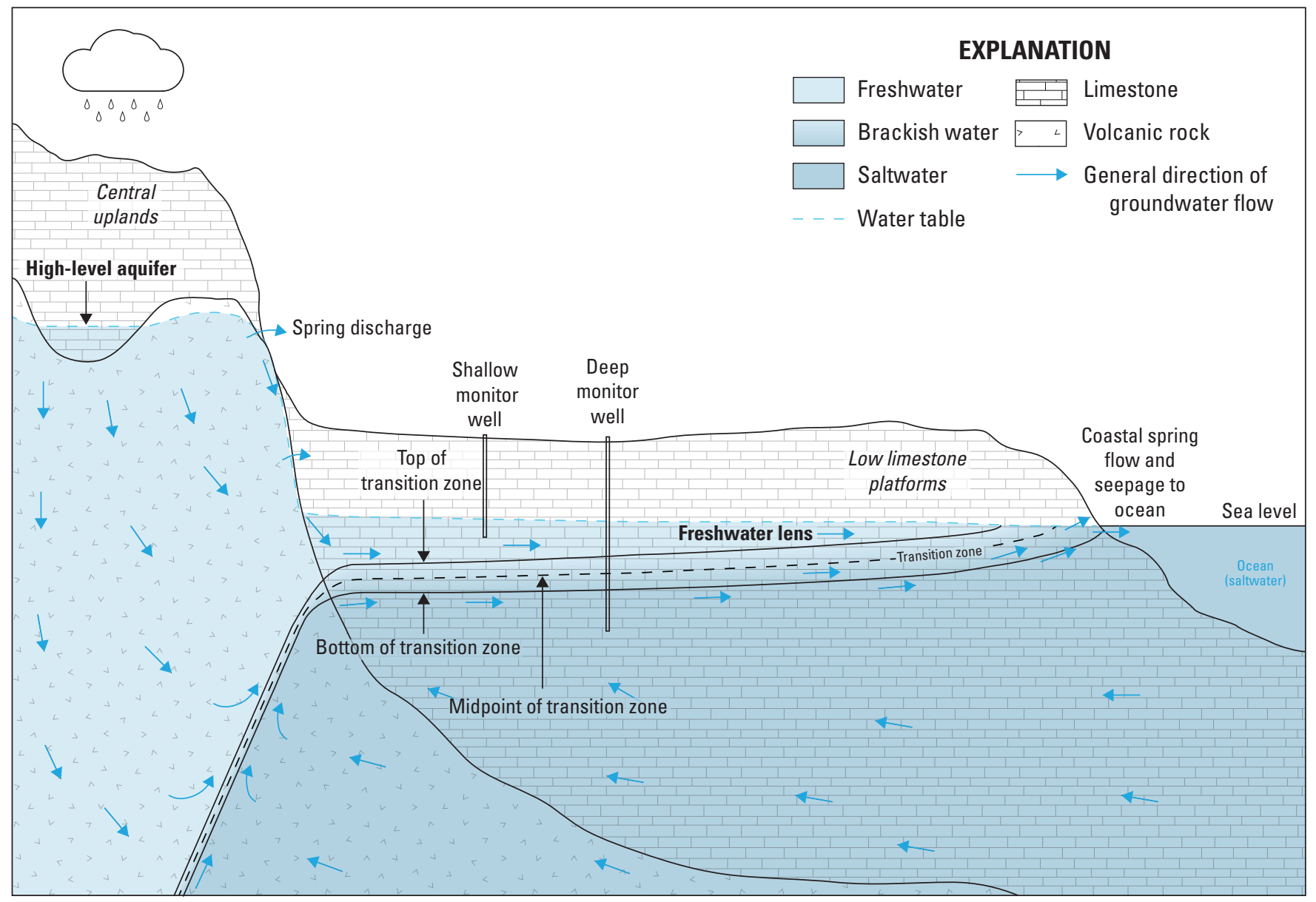

Figure 8. Schematic cross section showing groundwater occurrence, movement, and salinity structure in part of Saipan, Commonwealth of the Northern Mariana Islands (modified from Carruth, 2003). 
water from high-level aquifers and the absence of a tidal influence on groundwater levels indicate that these aquifers are not sensitive to the influence of saltwater, unlike groundwater in a freshwater-lens system (Van Der Brug, 1985; Carruth, 2003). Groundwater discharge from high-level aquifers recharges the freshwater-lens system and may form springs where the contact between limestone and volcanic rocks intersects with the land surface. Groundwater levels in the high-level aquifers range from a few tens of feet to several hundred feet above sea level (Carruth, 2003). Groundwater development from the high-level aquifers is limited because the small volume of stored water and bounded conditions result in large groundwater-level declines if withdrawal rates are too high (Van Der Brug, 1985). For example, during the 1982-83 drought on Saipan, wells in the Akgak well field in central Saipan were pumped extensively and groundwater levels declined by as much as $16.5 \mathrm{ft}$ over a 12-month period (Van Der Brug, 1986).

\section{Saltwater Intrusion}

Saltwater intrusion, which typically refers to the landward or upward movement of saltwater, is one of the primary threats to the availability of fresh groundwater within Saipan's freshwater-lens system (Carruth, 2003; Werner and others, 2013). Causes of saltwater intrusion include groundwater withdrawals and drought. When freshwater is withdrawn at a steady rate from a freshwater-lens system that was previously at equilibrium, groundwater levels will decline, and the transition zone will rise until a new equilibrium is reached between the amount of groundwater discharge and recharge (fig. 9). Furthermore, if groundwater is withdrawn from a previously undeveloped aquifer, the freshwaterlens system may take many months to years to reach a new equilibrium (Mather, 1975).

Groundwater withdrawals can have local and regional effects on groundwater levels and quality. Production wells that are drilled close to the transition zone or have high withdrawal rates may induce saltwater upconing, which refers to the upward movement of saltwater toward a pumped well (Reilly and Goodman, 1987) (fig. 10). If several production wells are close to one another, saltwater upconing below one well may increase the salinity of water pumped from nearby wells (Jakovovic, 2016). On a regional scale, groundwater withdrawals will result in a loss of freshwater from storage and could contribute to increases in the salinity of water withdrawn from wells (White and Falkland, 2010).

Drought on Pacific islands, often associated with El Niño phases of the ENSO cycle, results in decreased recharge to the freshwater-lens system and increases in the chloride concentrations of groundwater withdrawals (Van Der Brug, 1986;
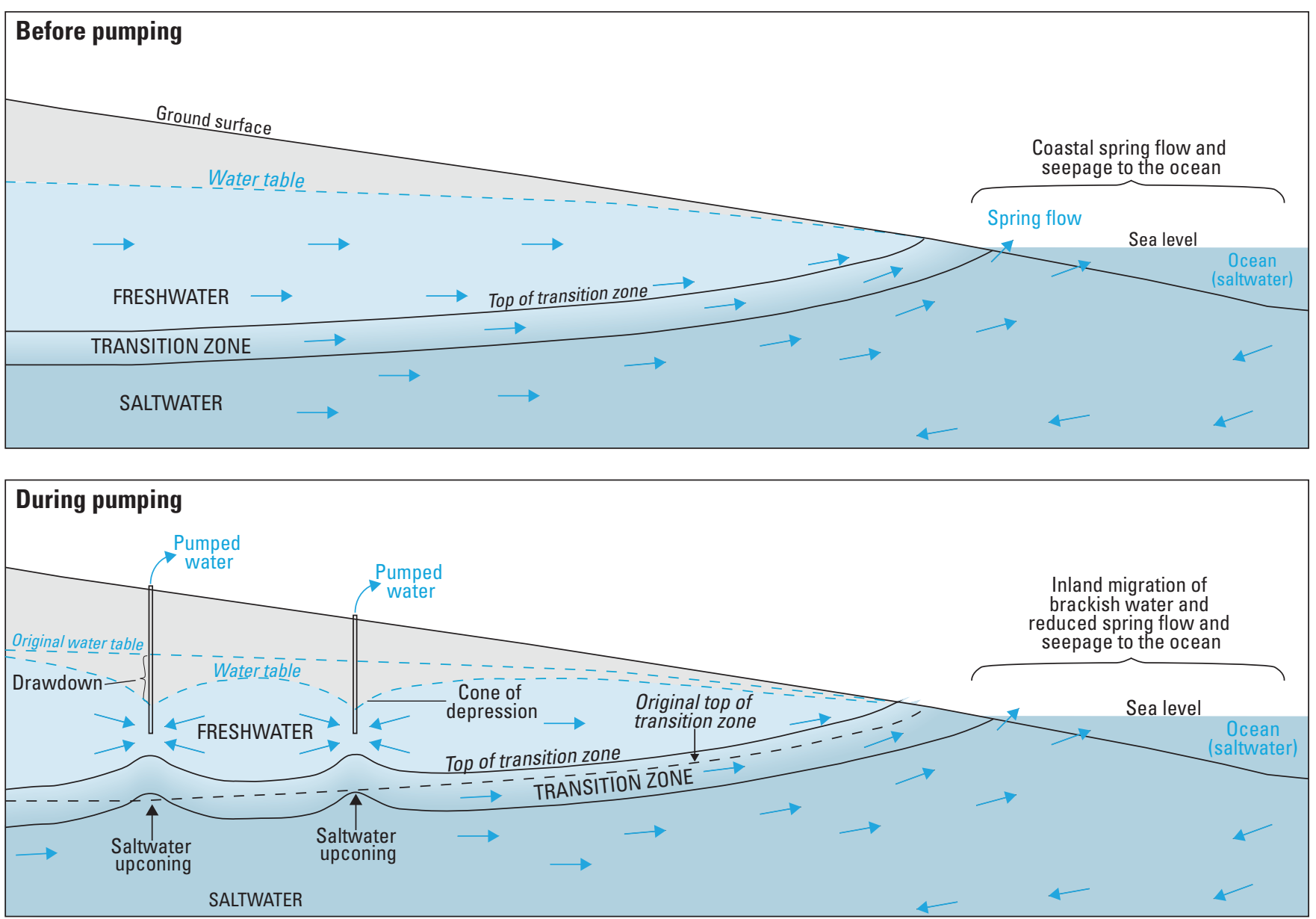

Figure 9. Schematics of the effects of groundwater withdrawal on the freshwater-lens system of a high-permeability island aquifer (modified from Izuka, 1999; Carruth, 2003). 
Low chloride concentrations result from wells that do not penetrate too close to the transition zone and are not pumped at high rates

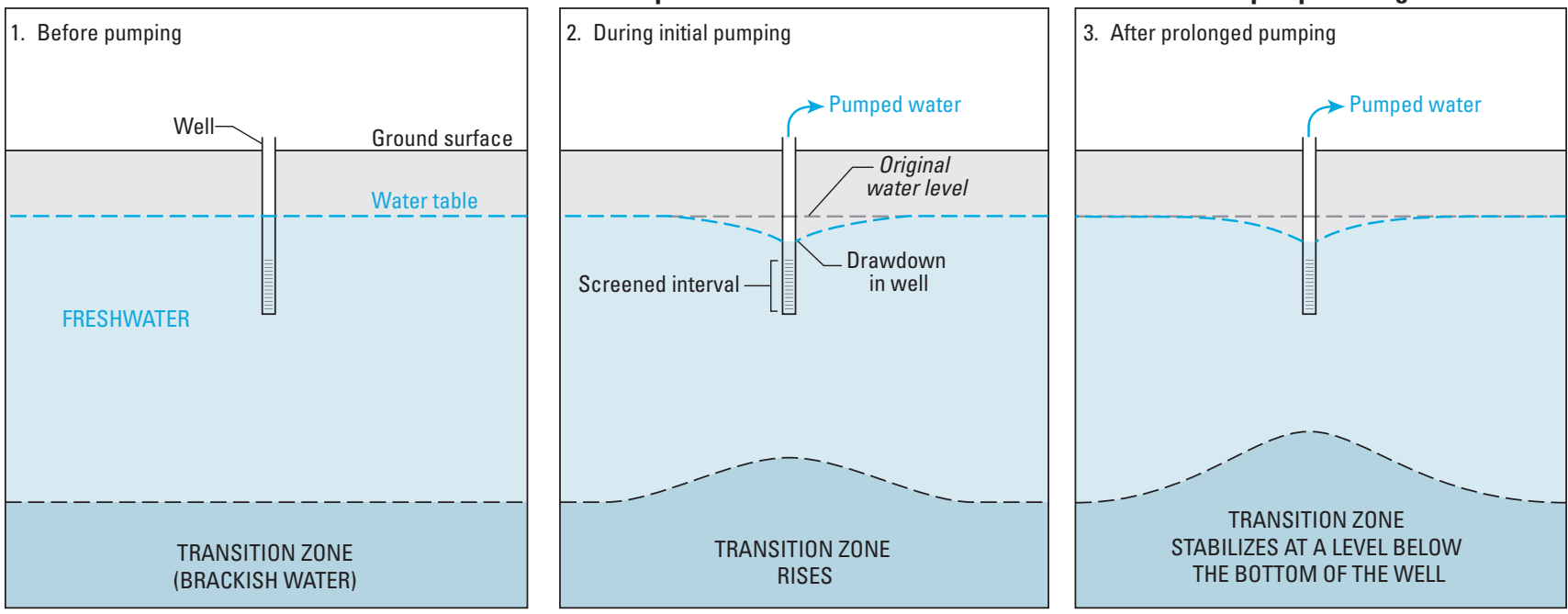

High chloride concentrations result from wells that penetrate into the freshwater-saltwater transition zone
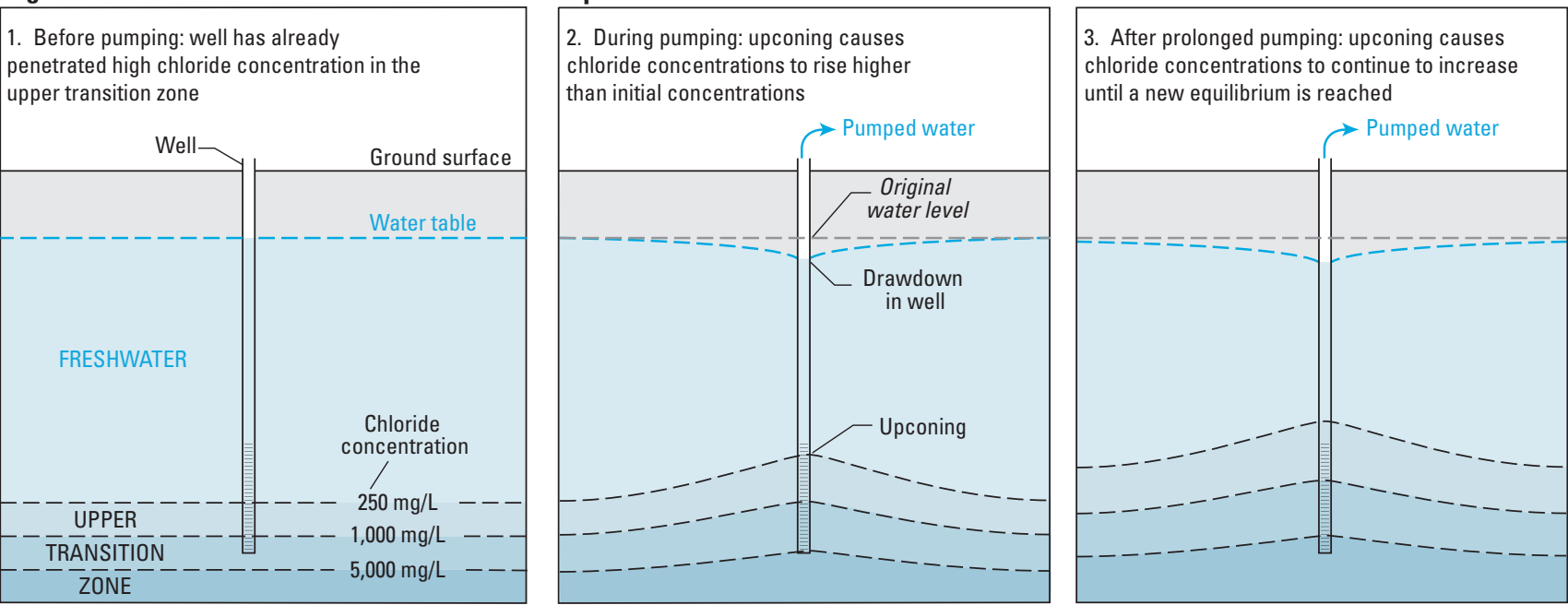

Chloride concentrations increase over time from wells that penetrate too close to the transition zone and (or) are pumped at high rates
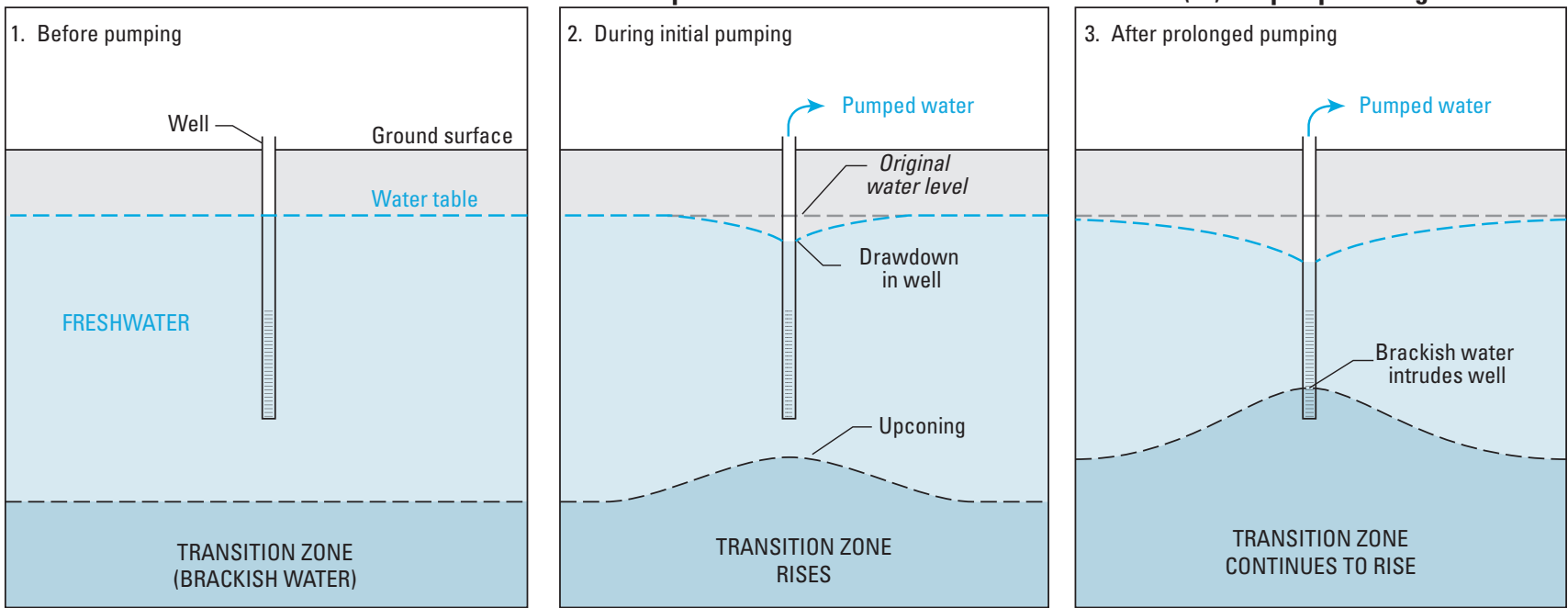

Figure 10. Diagrams of general examples of saltwater upconing in a coastal aquifer that show: Upper panel shows low chloride concentrations result from wells that do not penetrate too close to the transition zone and are not pumped at high rates. Middle panel shows high initial chloride concentrations result from a well that penetrated into the freshwater-saltwater transition zone. Lower panel shows chloride concentrations increase as a result of pumping from a well that penetrates too close to the transition zone and (or) is pumped at a rate that is high given the proximity of the bottom of the well to the transition zone. Modified from Izuka (1999) and Carruth (2003). 
Johnson, 2012; Mair and others, 2013). For example, during a drought in 1982-83, the mean chloride concentration of groundwater withdrawals on Saipan increased by a third to a value of 878 milligrams per liter (mg/L) (Van Der Brug, 1986). During a drought in 1998, the mean volume-weighted chloride concentration for municipal production wells on Saipan increased from about 850 to $1,150 \mathrm{mg} / \mathrm{L}$ (Carruth, 2003).

Management of saltwater intrusion generally focuses on prevention and monitoring because remediation of affected aquifers can be an intensive, expensive, and time-consuming process (Bear and others, 1999; Werner and others, 2011). To reduce saltwater intrusion in a freshwater-lens system, production wells generally are (1) drilled to depths that result in wells that withdraw water mainly from the top of the freshwater lens, (2) spaced far apart, and (3) pumped at low, uniform, and constant rates (Carruth, 2003; Barlow and Reichard, 2010).

Chloride concentrations of water pumped from existing well fields may be lowered by (1) reducing withdrawal rates, or (2) backfilling production wells that withdraw high-salinity water. Selection of well depths and locations of new production wells that considers potential saltwater intrusion is important for groundwater management (White and Falkland, 2010; Jakovovic and others, 2016). Monitoring of saltwater intrusion commonly includes the collection of both groundwater-level and salinity data, which can be evaluated to assess saltwater movement in an aquifer (Barlow, 2003; Barlow and Reichard, 2010; Werner and others, 2013).

High-salinity measurements at a well are not necessarily an indication of saltwater intrusion. The location and construction of a well may result in high-salinity water in the well, independent of the effects of groundwater withdrawals or drought. For example, the well could be drilled into a karst conduit with direct connection to saltwater, enabling saltwater to easily flow upward and mix with the freshwater lens. Collection and analysis of long-term groundwater-level and waterquality data will lead to a better understanding of groundwater conditions and saltwater intrusion at a network of wells.

\section{Groundwater Wells}

Groundwater wells on Saipan include (1) municipal production wells, (2) private production wells operated by hotels and other entities, and (3) monitor wells (fig. 7).

\section{Production Wells}

On Saipan, groundwater is the primary source of municipal water and currently is withdrawn from about 140 vertical wells, two Maui-type shafts (consisting of a shaft excavated to or below the water table, and one or more infiltration tunnels extending outward from the shaft), and one spring (Donni Spring), hereinafter collectively referred to as municipal production wells (at the time of publication, the data had not been published by the CUC).
Municipal production wells on Saipan generally were drilled with the intent of withdrawing water from the top of the freshwater lens to mitigate the upward migration of underlying saltwater and prevent contamination of the freshwater supply. For this report, municipal wells were divided into 14 generalized well fields (figs. 7, 11) based on the well fields described by Carruth (2003), geographic and geologic features, and regions used by the CUC. The following wellfield designations were modified from those described by Carruth (2003): (1) the San Vicente well field was merged into the Dan Dan well field; and (2) Maui IV Shaft was included in the Sablan Quarry well field, rather than having its own well field (fig. 11). The four well fields on Saipan's southern plateau (Dan Dan, Isley Field, Koblerville, and Obyan) contain about 56 percent of the municipal production wells. The Kagman well field on the Kagman Peninsula contains about 15 percent of the municipal production wells. The remaining municipal production wells are separated into nine well fields that are mostly within the central uplands or near the western coastal plain.

About 90 percent of the municipal production wells are in well fields that withdraw water from the freshwater-lens system; these wells generally have bottom depths ranging from about $0-30 \mathrm{ft}$ below sea level (Carruth, 2003). The remaining 11 wells withdraw water from high-level aquifers and are divided into the Akgak, Capitol Hill, and Donni Spring well fields.

In addition to the municipal production wells, at least 135 private production wells have been drilled on Saipan (fig. 7), of which 112 are used for drinking water, 16 are used for irrigation, and 7 are used for industrial purposes, according to the Bureau of Environmental and Coastal Quality (BECQ) (at the time of publication, the data had not been published by the BECQ). The private production wells generally are concentrated on the western coastal plain and most are outside of the municipal well-field areas. Many of the private production wells used for drinking water are connected to reverse-osmosis systems to reduce the salinity of the water. In general, private production wells with reverse-osmosis systems on Saipan are drilled about $100-120 \mathrm{ft}$ deep. High-salinity wastewater produced by reverse-osmosis systems is injected into the ground through injection wells drilled about 220-240 ft deep (Glenn Arriola, BECQ, written commun., 2019).

\section{Monitor Wells}

Saipan has 14 monitor wells (table 1), which are in 8 of the 14 well fields (fig. 7). The monitor wells were drilled between 1945 and 2005, with most of the wells drilled during the 1990s. Monitor wells that penetrate the transition zone of a freshwater-lens system and that are open to the aquifer are sometimes referred to as deep monitor wells (fig. 8). Deep monitor wells can be used to measure the vertical distribution of salinity in the aquifer and determine the thickness of the freshwater lens. 


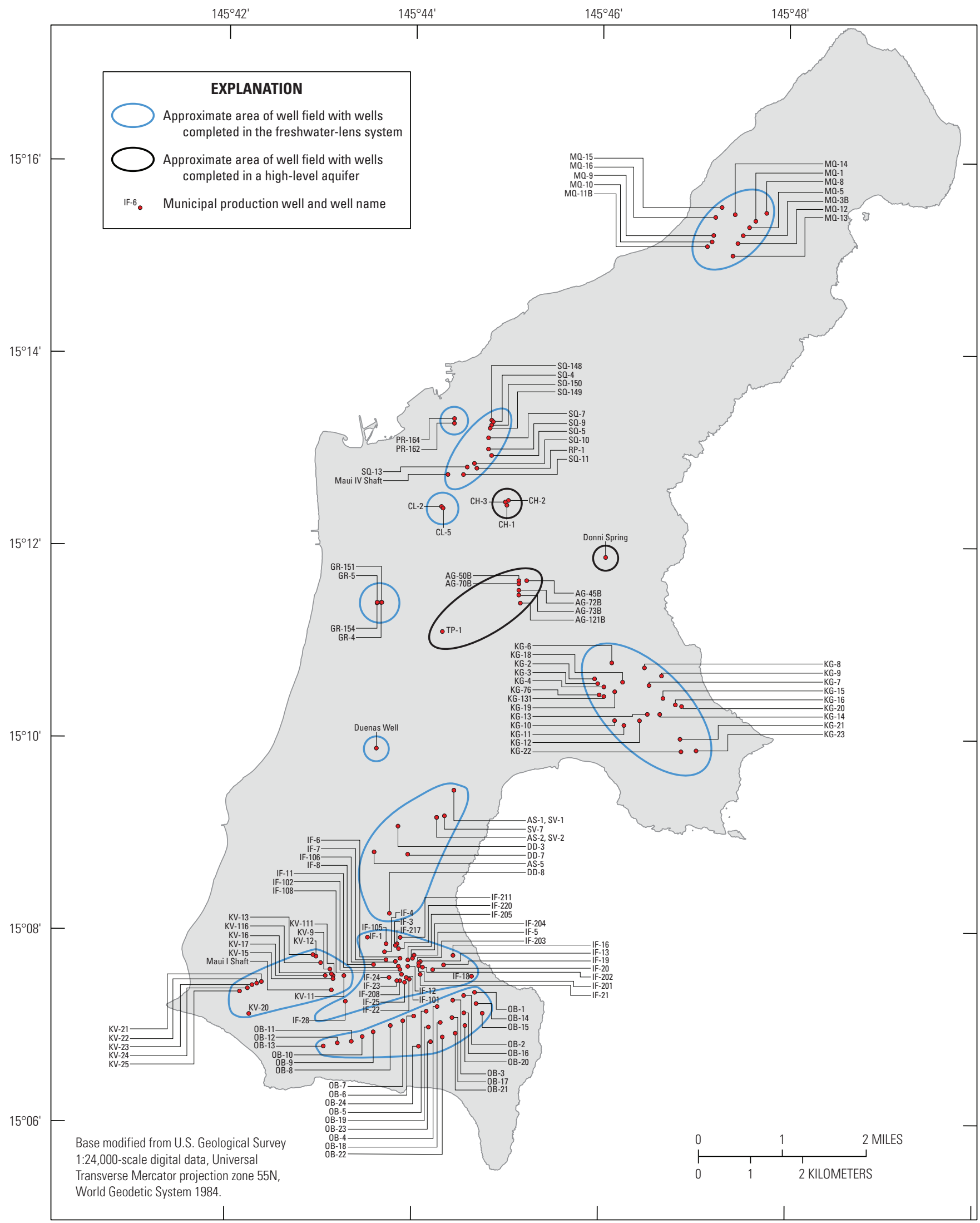

Figure 11. Map of municipal wells and well names, monitor wells, and well fields, Saipan, Commonwealth of the Northern Mariana Islands. Monitor- and municipal-well locations are from Carruth (2003) and the Commonwealth Utilities Corporation (at the time of publication, the data had not been published by the Commonwealth Utilities Corporation). 


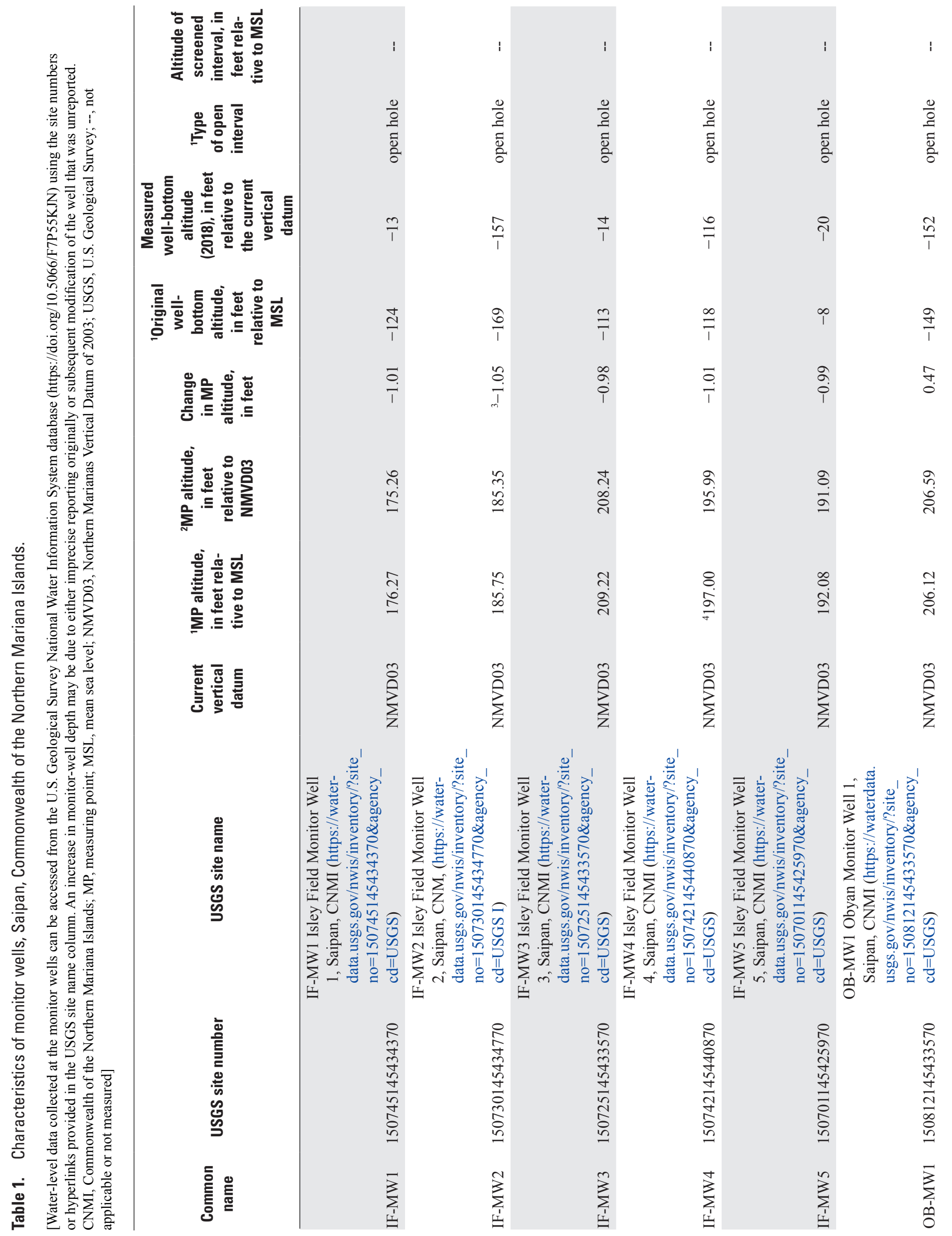




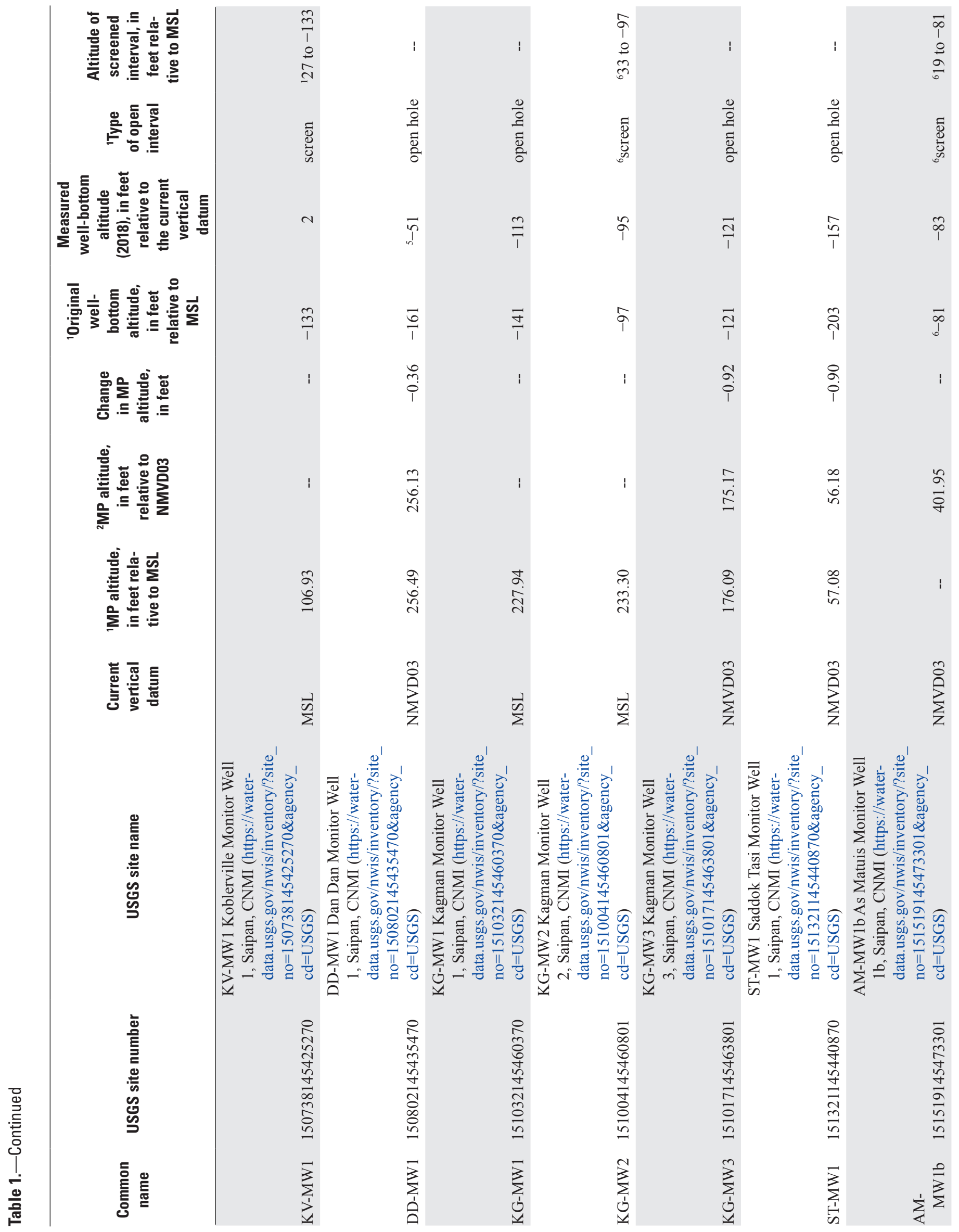




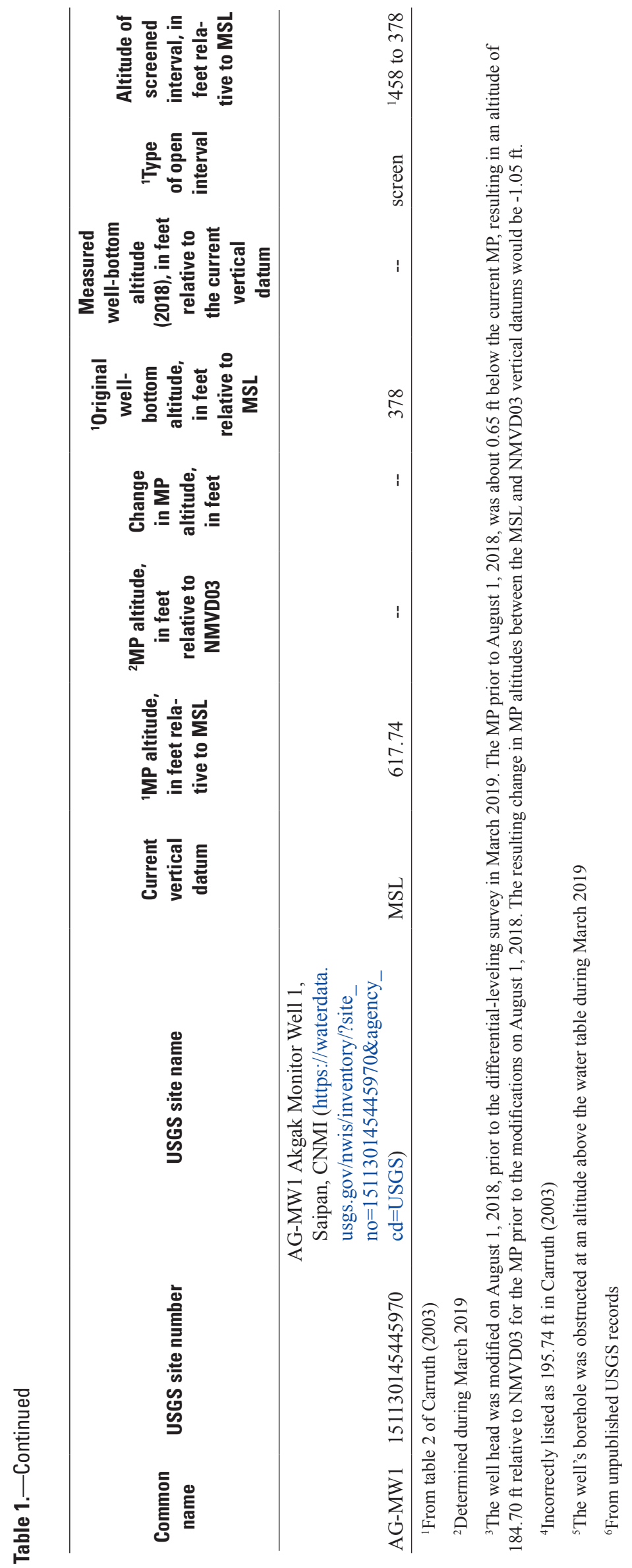


Since the monitor wells were constructed, many of the wells have had their depths reduced because of debris falling in the well. During site visits to wells in 2018-19, substantial obstructions were detected within the boreholes of monitor wells DD-MW1, IF-MW1, IF-MW3, and KV-MW1 (table 1). Data were collected from DD-MW1, IF-MW1, and IF-MW3; however, no data were collected from KV-MW1 because it was obstructed above the water table during the first site visit in 2018. Monitor wells AG-MW1, which is drilled into a highlevel aquifer, and KV-MW1 were not used for this study but are listed in table 1 to show the complete network of monitor wells on Saipan.

\section{Vertical Datum}

Each monitor well on Saipan has a reference mark called a measuring point, generally near the top of the well's casing. The altitude of a well's measuring point must be known before the altitudes of other features in the wellsuch as the water table, top and midpoint of the groundwater transition zone, and well bottom - can be determined. In order to evaluate and compare the altitudes of features and groundwater data for a network of monitor wells, the measuring-point altitudes of the wells must be known and referenced to a common vertical datum.

The measuring-point altitudes of monitor wells on Saipan were originally surveyed by the USGS in 1969 from benchmarks whose altitudes were referenced to a vertical datum defined as "mean sea level," established using 29 days of tide-gage data collected during December 1968-January 1969 (Carlson and others, 2009). These benchmark altitudes were the source of vertical control for data collected from production wells and monitor wells until 2018.

In March 2019, the USGS surveyed the measuring-point altitudes of 10 monitor wells (table 1) using line leveling from benchmarks whose altitudes had been referenced to a new vertical datum, the Northern Marianas Vertical Datum of 2003 (NMVD03). The NMVD03 datum was established relative to mean sea level for the 1983-2001 National Tidal Datum Epoch (Carlson and others, 2009); that is, $0 \mathrm{ft}$ NMVD03 is about equal to local mean sea level during 1983-2001. The four remaining monitor wells in the monitor-well network were not surveyed because they were not as critical for the current study and time was limited.

For the 10 monitor wells that were surveyed in March 2019, the measuring-point altitudes referenced to NMVD03 generally were $0.9-1.0 \mathrm{ft}$ lower than the measuring-point altitudes referenced to the old mean sea level datum (table 1). Offsets of similar magnitudes were described for the benchmark altitudes on Saipan in Carlson and others (2009) after changing the datum from mean sea level to NMVD03. Therefore, most of the apparent decreases in measuringpoint altitudes of the monitor wells were likely a result of the NMVD03 datum being offset upwards from the previously used mean sea level datum by about $0.9-1.0 \mathrm{ft}$. Offsets in the measuring-point altitudes for at least two of the monitor wells (OB-MW1 and DD-MW1), however, may have been influenced by well-head modifications.

Currently (2019), for the 10 monitor wells whose measuring points were surveyed to NMVD03 in March 2019 (table 1), all groundwater-level data collected by the USGS between 1969 and 2017 and stored in the USGS National Water Information System (NWIS) database are referenced to the mean sea level datum, and all groundwater-level data collected by the USGS since 2018 and stored in the NWIS database are referenced to the NMVD03 datum (U.S. Geological Survey, 2019). For the remaining four monitor wells (AG-MW1, KG-MW1, KG-MW2, and KV-MW1), all groundwater-level data collected by the USGS since 1969 and stored in NWIS are referenced to the mean sea level datum. The groundwater-level data collected before 2018, using a vertical datum of mean sea level, were not adjusted to NMVD03 for the current report because of uncertainty regarding the change in measuring-point altitudes.

\section{Groundwater Data}

Proper management of an island's groundwater resources requires the collection, analysis, and reporting of reliable groundwater data. Available groundwater data for Saipan include groundwater-recharge estimates, groundwater-level measurements in monitor wells, groundwater-withdrawal measurements for municipal production wells, chlorideconcentration measurements of groundwater withdrawn from municipal production wells, and salinity-profile measurements in monitor wells.

\section{Recharge}

All fresh groundwater on Saipan originates as rainfall. Rain that falls on Saipan subsequently evaporates, is used by plants, runs off the land surface into the ocean, or recharges groundwater. Groundwater recharge on Saipan has been estimated by several investigators. Ayers (1981) estimated that recharge over the Akgak area of central Saipan was about 29.6-34.3 inches per year (in/yr) (about 40-46 percent of rainfall) using limited rainfall data during 1968-81 from a raingaging station in the Kagman area. Nance (1983) estimated that recharge over flat, permeable basins (that is, limestone areas) was about $24.3 \mathrm{in} / \mathrm{yr}$ (30 percent of rainfall) and that recharge over steep, poorly permeable basins (that is, volcanic areas) was about $12.8 \mathrm{in} / \mathrm{yr}$ (about 16 percent of rainfall)—both estimates assumed a mean annual rainfall of $80 \mathrm{in} / \mathrm{yr}$. Mink (1987) used methods developed for the limestone terrain of northern Guam to estimate that recharge over the limestone areas on Saipan was about $40 \mathrm{in} / \mathrm{yr}$ (about 50 percent of rainfall), assuming a mean annual rainfall of $80 \mathrm{in} / \mathrm{yr}$. Additionally, Ayers (1981) and Nance (1983) suggested that negligible recharge would occur during the dry-season months of December-June, which is consistent with Johnson's (2012) recharge estimate for northern Guam that used a comprehensive water budget. 


\section{Water Levels}

Measurements of groundwater levels (water levels) in wells can be used to (1) evaluate an aquifer's response to hydrologic stresses, including recharge and groundwater withdrawals, and (2) infer the directions of groundwater flow. Additionally, water-level measurements over time can show long-term changes in freshwater storage because, as described by the Ghyben-Herzberg principle in the Freshwater

Lens section, water level is related to the thickness of the freshwater lens.

Water-level data for Saipan include discrete water-level measurements collected by the USGS, which are available for the 14 monitor wells between 1986-2019. Continuous waterlevel measurements collected by the USGS are available for seven of the monitor wells between 1998-2005. The USGS water-level data are stored in the NWIS database, accessible at https://waterdata.usgs.gov/nwis. The data can be accessed from the NWIS database using the USGS site numbers or hyperlinks provided in table 1. Additional water-level data collected in wells on Saipan prior to 1986 are described by Van Der Brug (1985). The discrete water-level measurements collected during 2018-19 were not compared to the waterlevel data collected during 1986-2005 in this report because of uncertainty regarding the change in measuring-point altitudes. The remaining paragraphs in this section mostly summarize existing descriptions and interpretations of waterlevel data for Saipan.

\section{Water Levels in the Freshwater-Lens System}

Water levels in wells drilled into the freshwater-lens system on Saipan respond to short- and long-term changes in rainfall, sea level, and groundwater withdrawals (Van Der Brug, 1985; Hoffmann and others, 1998; Carruth, 2003). Measured water levels from wells in the freshwater-lens system range from about 1 to $3 \mathrm{ft}$ above sea level and generally increase inland (Carruth, 2003). Saipan has an ocean tidal range of about 1.5-2.5 ft (Caldwell and others, 2015), and semidiurnal water-level fluctuations caused by ocean tides are greatest at the coast and generally are attenuated with increasing distance inland from the coast. The tidal amplitude in a well also is a function of the permeability and storage properties of the aquifer between the coast and the well (Townley, 1995). Carruth (2003) showed that semidiurnal water-level changes in well KG-MW3, located about 3,000 ft inland from the coast, averaged about $0.25 \mathrm{ft}$ in response to ocean tides. Monitor wells IF-MW1 and OB-MW1, located about 4,500 and 3,700 ft inland from the coast, respectively, showed no measurable water-level changes in response to ocean tides.

Water levels in the freshwater-lens system also vary over longer periods in response to non-tidal changes in sea level. For example, daily mean water levels in four monitor wells (KG-MW3, KV-MW1, OB-MW1, and IF-MW1) generally followed the upward and downward trends of daily mean sea levels near Saipan during 1998-2003 (fig. 12B).
Owing to the generally high permeabilities of the soil and rock above the freshwater-lens system on Saipan, water levels can rapidly increase in response to rainfall. For example, water levels in three monitor wells (KG-MW3, KV-MW1, and OB-MW1) rose about $0.2-0.4 \mathrm{ft}$ on December 9, 2002, when about 7.5 inches of rain fell at Saipan International Airport, although the water-level increase may also be related to other factors, including changes in sea level and barometric pressure (fig. 13).

\section{Water Levels in High-Level Aquifers}

Water levels measured in high-level aquifers range from about 30 to $600 \mathrm{ft}$ above sea level and generally increase with increasing land-surface altitude (Carruth, 2003). Water levels in these aquifers mainly are controlled by geology, rainfall, groundwater withdrawals, and barometric pressure, and do not respond to short- or long-term changes in sea level (Carruth, 2003).

\section{Discharge}

Groundwater discharge on Saipan occurs from (1) withdrawals from wells and discharge from inland springs; (2) coastal discharge to the ocean, including springs and submarine seepage; and (3) discharge to streams as base flow. Withdrawals from wells and discharge from inland springs have been measured, although records are incomplete for some periods and locations. Quantitative estimates of coastal groundwater discharge from Saipan were not known to exist at the time this report was prepared. [A study containing estimates of submarine groundwater discharge for Saipan's west coast was published in late 2020; see Knapp and others, 2020.] Groundwater discharge to streams generally is limited to the Talufofo Stream Basin in the northeast part of the island and has been estimated for a few locations (see, Izuka and Ewart, 1995) (fig. 1). Groundwater discharge to streams is not described in this report because no new data have been collected since 1995 and groundwater discharge to streams is assumed to be minor compared to island-wide groundwater withdrawals from wells and inland springs, and coastal groundwater discharge. Assuming steady-state conditions, if discharge to streams is small, then discharge is mainly in the form of withdrawals from wells, inland springs, and coastal discharge. Groundwater withdrawals from wells and inland springs are described next.

\section{Withdrawals from Wells}

Withdrawals from drilled wells began after the American occupation of Saipan during World War II (Van Der Brug, 1985). Mean groundwater withdrawals for Saipan were about $2 \mathrm{Mgal} / \mathrm{d}$ during 1946-48 and were between about 0.4 and $0.9 \mathrm{Mgal} / \mathrm{d}$ during 1951-56 (Van Der Brug, 1985). Subsequent records of withdrawals are sparse until 1995 (Van Der Brug, 1985; Carruth, 2000; Carruth, 2003). During 1995-2000, municipal groundwater withdrawals ranged from about 8 to $11 \mathrm{Mgal} / \mathrm{d}$ (Carruth, 2003). 

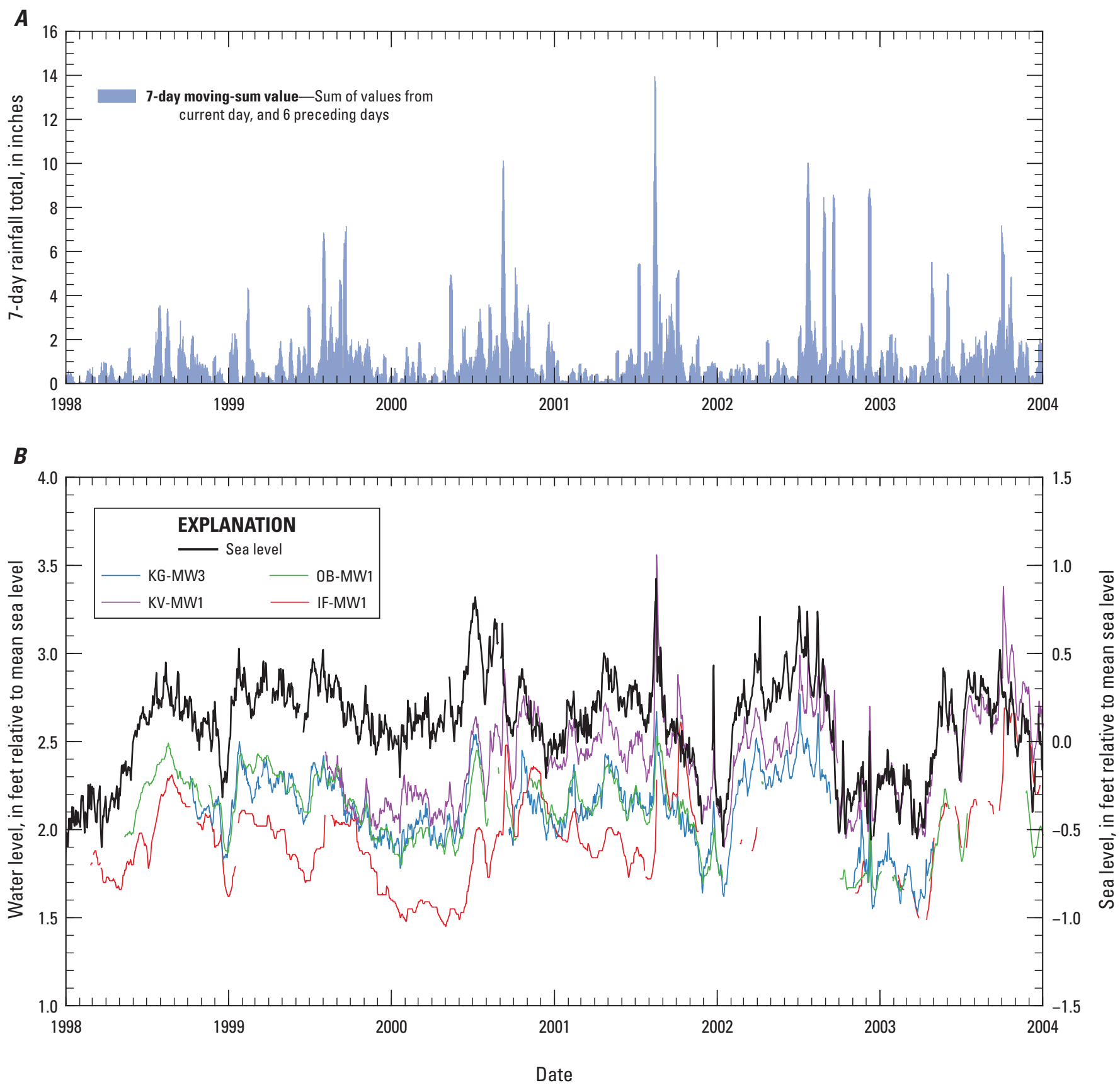

Figure 12. A, Graph of 7-day moving sum of daily rainfall at Saipan International Airport, Saipan, Commonwealth of the Northern Mariana Islands, 1998-2003. B, Graph of daily mean groundwater levels at selected monitor wells and daily mean sea level, Saipan, Commonwealth of the Northern Mariana Islands, 1998-2003. Gaps in the water-level and sea-level data indicate missing data. Rainfall data are from the National Oceanic and Atmospheric Administration (2019). Water-level data are from the U.S. Geological Survey National Water Information System database (USGS, 2019). Sea-level data are from Caldwell and others (2015). 


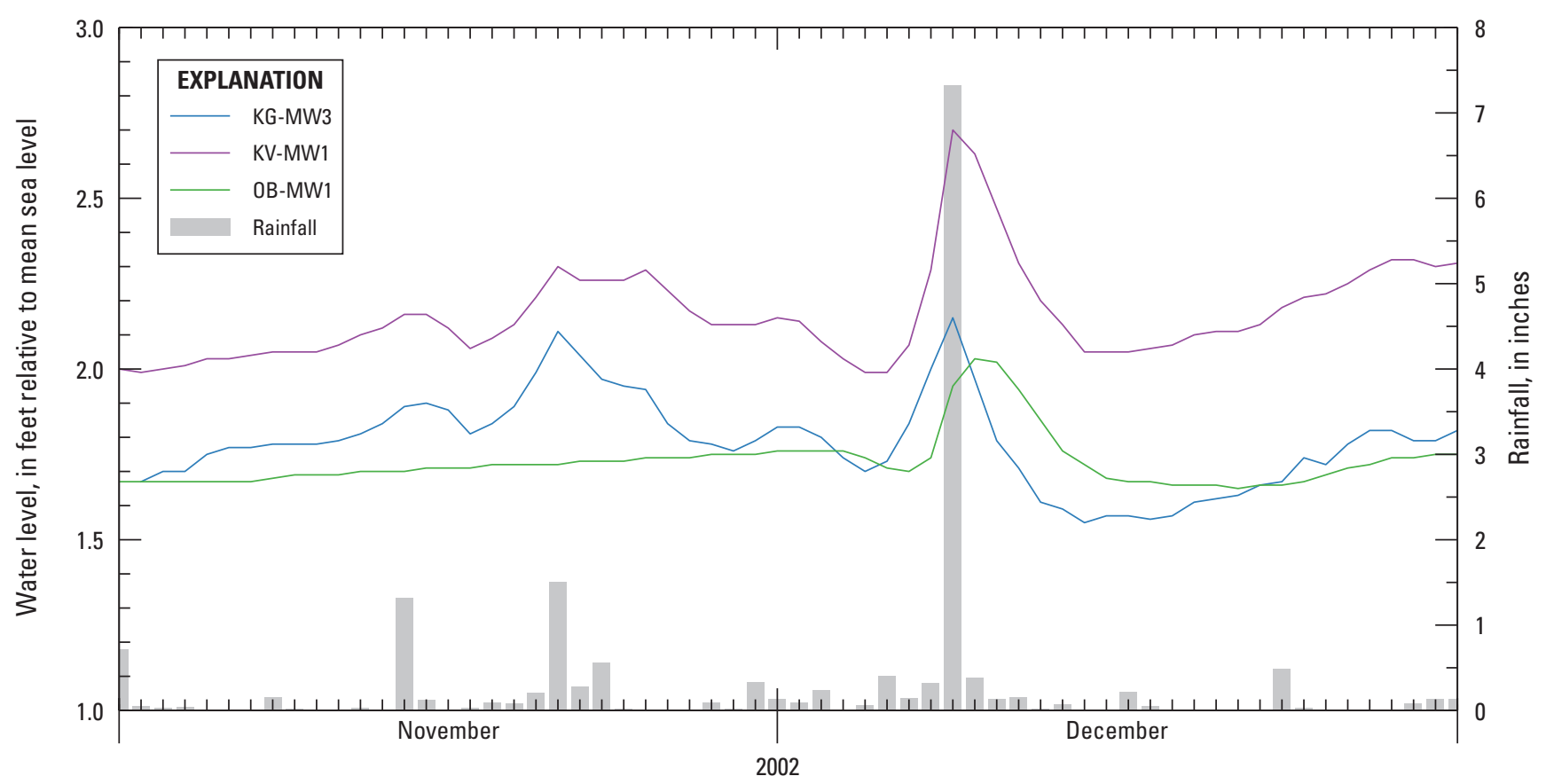

Figure 13. Graph of daily mean groundwater levels at selected monitor wells, and daily rainfall at Saipan International Airport, Saipan, Commonwealth of the Northern Mariana Islands, November-December 2002. Waterlevel data are from the U.S. Geological Survey National Water Information System database (USGS, 2019). Rainfall data are from the National Oceanic and Atmospheric Administration (2019).

Records of groundwater withdrawals from municipal production wells for most months during May 2014-March 2019 were provided by the CUC and consist of monthly flowmeter readings at the wellheads (at the time of publication, the data had not been published by the CUC). The withdrawal data provided by the CUC also include records of water captured from Donni Spring during May 2014-March 2019. Donni Spring is the only spring currently used for municipal water supply. The BECQ provided permitted pump rates for the private wells on Saipan (at the time of publication, the data had not been published by the BECQ).

\section{Withdrawals from Municipal Production Wells, May 2014 March 2019}

Monthly withdrawals from municipal wells on Saipan during May 2014-March 2019 ranged from about 5.7 to $12.8 \mathrm{Mgal} / \mathrm{d}$ and averaged $9.3 \mathrm{Mgal} / \mathrm{d}$ (fig. 14). Monthly groundwater withdrawals generally do not appear to vary seasonally. The monthly withdrawals shown in figure 14 include water from Donni Spring, however, where withdrawals generally were greater during the wet season than during the dry season because of increased spring flow. A fraction of the groundwater withdrawn from production wells is lost to leakage before reaching the final distribution point, which is not uncommon for water-distribution systems. CUC has ongoing programs to reduce loss rates.

Most municipal production wells on Saipan are operated continuously unless maintenance is needed (Carruth, 2003).

Pumping the wells continuously may help to reduce the salinity and chloride concentration of groundwater withdrawals because it reduces the vertical oscillation of the transition zone that would occur if the pumps were cycled on and off to meet diurnal demand patterns - the vertical oscillation of the transition zone increases freshwater and saltwater mixing and expands the transition zone (Visher and Mink, 1964; Mather, 1975; and Underwood and others, 1992). Wells drilled into the freshwater-lens system generally have withdrawal rates of about 40-60 gallons per minute (gal/min); wells drilled into high-level aquifers have withdrawal rates of about $60-120 \mathrm{gal} / \mathrm{min}$.

As of 2019, about 80-90 percent of municipal groundwater withdrawals are from wells drilled into the freshwaterlens system. The southernmost well fields (Koblerville, Isley Field, and Obyan) generally have the highest total pumpage and accounted for about 47 percent of municipal groundwater withdrawals during 2014-19 (fig. 15). Because withdrawal rates for production wells in the freshwater-lens system generally are uniform, the well fields with the greatest withdrawals during 2014-19 are those with the most wells. 


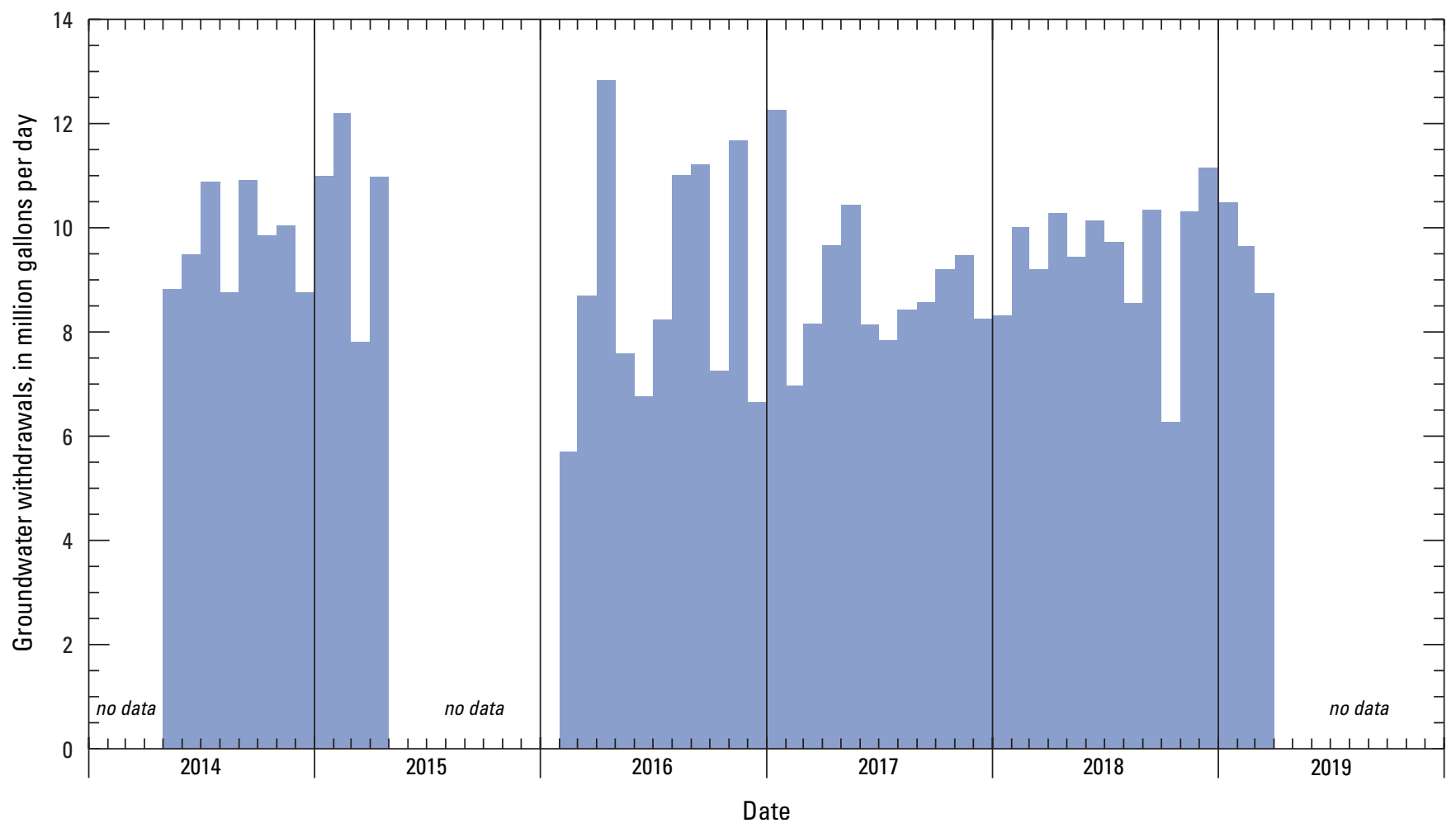

Figure 14. Graph of monthly groundwater withdrawals from municipal wells, May 2014-April 2015 and February 2016March 2019, Saipan, Commonwealth of the Northern Mariana Islands. Months without a bar indicate no available record. Data are from the Commonwealth Utilities Corporation (at the time of publication, the data had not been published by the Commonwealth Utilities Corporation).

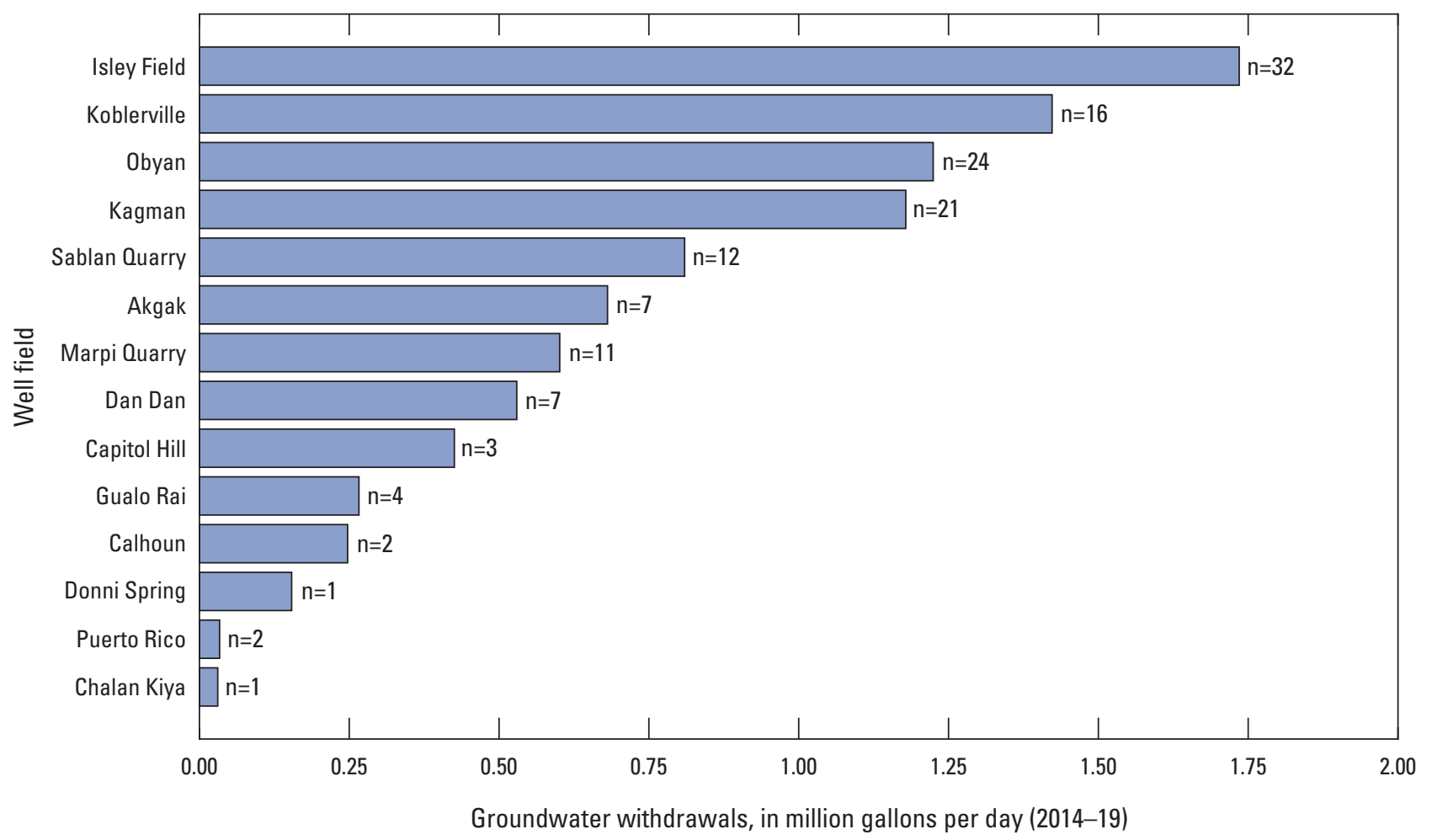

Figure 15. Graph of mean groundwater withdrawals from municipal well fields during May 2014-April 2015 and February 2016-March 2019, Saipan, Commonwealth of the Northern Mariana Islands. Data are from the Commonwealth Utilities Corporation (at the time of publication, the data had not been published by the Commonwealth Utilities Corporation). The number of municipal wells (n) with records of withdrawals during 2014-19 is shown on the right side of each bar. 


\section{Withdrawals from Private Production Wells}

The available withdrawal data for private production wells on Saipan include well locations and the permitted pump rates as of 2019 (at the time of publication, the data had not been published by the BECQ). The 135 private production wells on Saipan are permitted to withdraw a total of about $7.0 \mathrm{Mgal} / \mathrm{d}$ of groundwater. Most private production wells are permitted to withdraw groundwater at rates of about 30-40 $\mathrm{gal} / \mathrm{min}$ (fig. 16). Groundwater withdrawals from private wells are uncertain because records of the withdrawals are not available. Private wells classified as drinking water wells are permitted to withdraw a combined total of about $6.1 \mathrm{Mgal} / \mathrm{d}$, private wells classified as irrigation wells are permitted to withdraw a combined total of about $0.7 \mathrm{Mgal} / \mathrm{d}$, and private wells classified as industrial wells are permitted to withdraw a combined total of about $0.2 \mathrm{Mgal} / \mathrm{d}$. The largest private-well operators are hotels on the western coastal plain, which operate wells permitted to withdraw groundwater at rates ranging from about 50 to $250 \mathrm{gal} / \mathrm{min}$.

\section{Salinity}

For this report, measurements of specific conductance and chloride concentration are used to assess the salinity of Saipan's groundwater. Freshwater is defined as water with a chloride concentration less than or equal to $250 \mathrm{mg} / \mathrm{L}$ or a specific conductance less than or equal to 1,400 microsiemens per centimeter $(\mu \mathrm{S} / \mathrm{cm})$. A specific conductance of $1,400 \mu \mathrm{S} /$ $\mathrm{cm}$ is about equal to a chloride concentration of $250 \mathrm{mg} / \mathrm{L}$ for groundwater on Saipan - this relation is described in the section "Relation Between Chloride Concentration and Specific Conductance in Groundwater."

\section{Chloride Concentrations of Groundwater Withdrawals, 2009-19}

Records of the chloride concentrations of groundwater withdrawn from municipal production wells since 2000 were available for December 2009-February 2019 only and were provided by the CUC (at the time of publication, the data had not been published by the CUC). The records consist of chloride concentrations determined by the CUC for about 2,700 water samples collected from groundwater withdrawn from 146 production wells. Some of the production wells with chloride-concentration data are not as of 2019 in use. For most of the production wells, water samples for chlorideconcentration analysis were collected semiannually. During 2009-19, chloride concentrations were determined using titration with silver nitrate (Standard Method 4500-Cl-B, Argentometric Method).

Boxplots summarizing the chloride concentrations of groundwater samples collected from municipal production wells within 11 selected well fields during 2009-19 are shown in figure 17. The chloride concentrations of groundwater withdrawals from the three well fields developed in highlevel aquifers (Akgak, Capitol Hill, and Donni Spring) were not included in figure 17 because their boxplot ranges are too narrow to display at the same scale as the other well fields. The chloride concentrations of groundwater samples from wells drilled in high-level aquifers ranged from 12 to $54 \mathrm{mg} / \mathrm{L}$, and median chloride concentrations for each well ranged from 24 to $42 \mathrm{mg} / \mathrm{L}$ (fig. 18). In contrast, the chloride concentrations of groundwater samples from wells drilled in the freshwater-lens system ranged from 19 to $6,038 \mathrm{mg} / \mathrm{L}$, and median chloride concentrations for each well ranged from 93 to $3,083 \mathrm{mg} / \mathrm{L}$ (figs. 17, 18). Groundwater withdrawn from Isley Field, the well field with the greatest groundwater withdrawals during 2014-19, had a median chloride concentration of nearly 1,000 mg/L. Marpi Quarry, the only well field in the northern third of the island, had a median chloride concentration of $1,600 \mathrm{mg} / \mathrm{L}$ and the largest interquartile range of any well field.

Using the available chloride-concentration and groundwater-withdrawal data provided by the $\mathrm{CUC}$, the following statistics were determined for each municipal production well: (1) median chloride concentration of groundwater withdrawals during 2009-19; and (2) mean of the monthly groundwater withdrawals during 2014-19. Figure 19 summarizes these two statistics for each production well. About 22 percent of municipal production wells had median chloride concentrations less than $250 \mathrm{mg} / \mathrm{L}$, and about 43 percent had median chloride concentrations less than $500 \mathrm{mg} / \mathrm{L}$.

Five production wells within the Kagman well field had median chloride concentrations greater than $1,000 \mathrm{mg} / \mathrm{L}$. Two of these production wells, KG-6 and KG-131, had mean groundwater-withdrawal rates greater than $50 \mathrm{gal} /$ $\mathrm{min}$, whereas the remaining production wells in the Kagman well field had mean groundwater-withdrawal rates of $50 \mathrm{gal} /$ min or less. Therefore, the relatively high median chloride concentrations for KG-6 and KG-131 might be related to their relatively high groundwater-withdrawal rates. The high pumping rates at KG-6 and KG-131 could be inducing upward flow of saltwater beneath the wells and may be responsible for the high median chloride concentrations at nearby wells with relatively low withdrawal rates (for example, KG-3 and KG-4). The relatively high median chloride concentrations for KG-6 and KG-131, however, might be influenced by other factors, such as the altitude of the bottom of the well and the altitude of the screened interval.

Median chloride concentrations were less than or equal to $500 \mathrm{mg} / \mathrm{L}$ for about 71 percent of the wells in the Obyan well field. In contrast, median chloride concentrations were less than or equal to $500 \mathrm{mg} / \mathrm{L}$ for only 19 and 31 percent of the wells within the Isley Field and Koblerville well fields, respectively (fig. 19). The higher percentage of wells with low median chloride concentrations within the Obyan well field might be partly attributed to the relatively uniform spacing and long distances (at least $600 \mathrm{ft}$ ) between the production wells, 


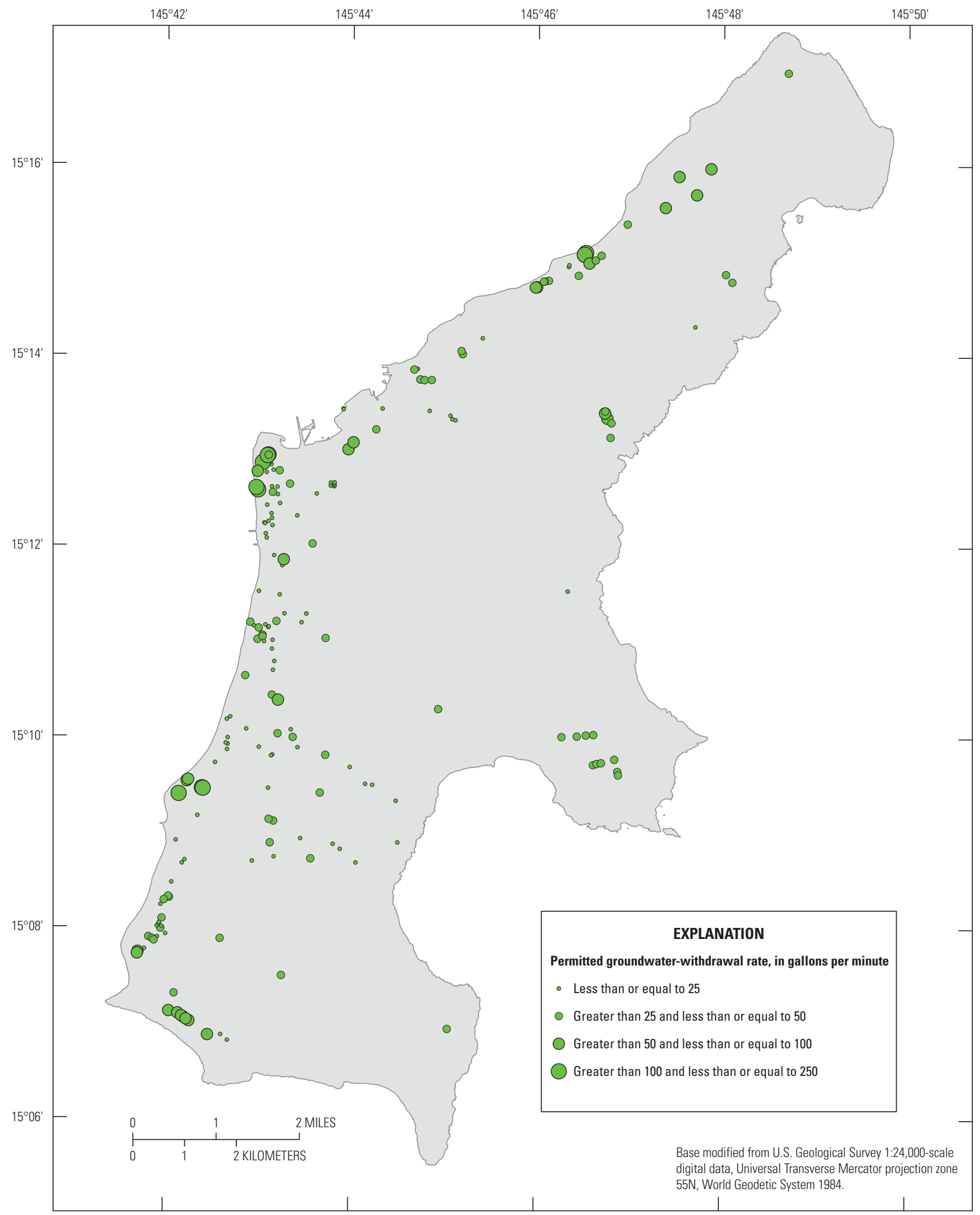

Figure 16. Map of permitted groundwater-withdrawal rates for private wells, Saipan, Commonwealth of the Northern Mariana Islands. Data are from the Bureau of Environmental and Coastal Quality (at the time of publication, the data had not been published by the Bureau of Environmental and Coastal Quality). 


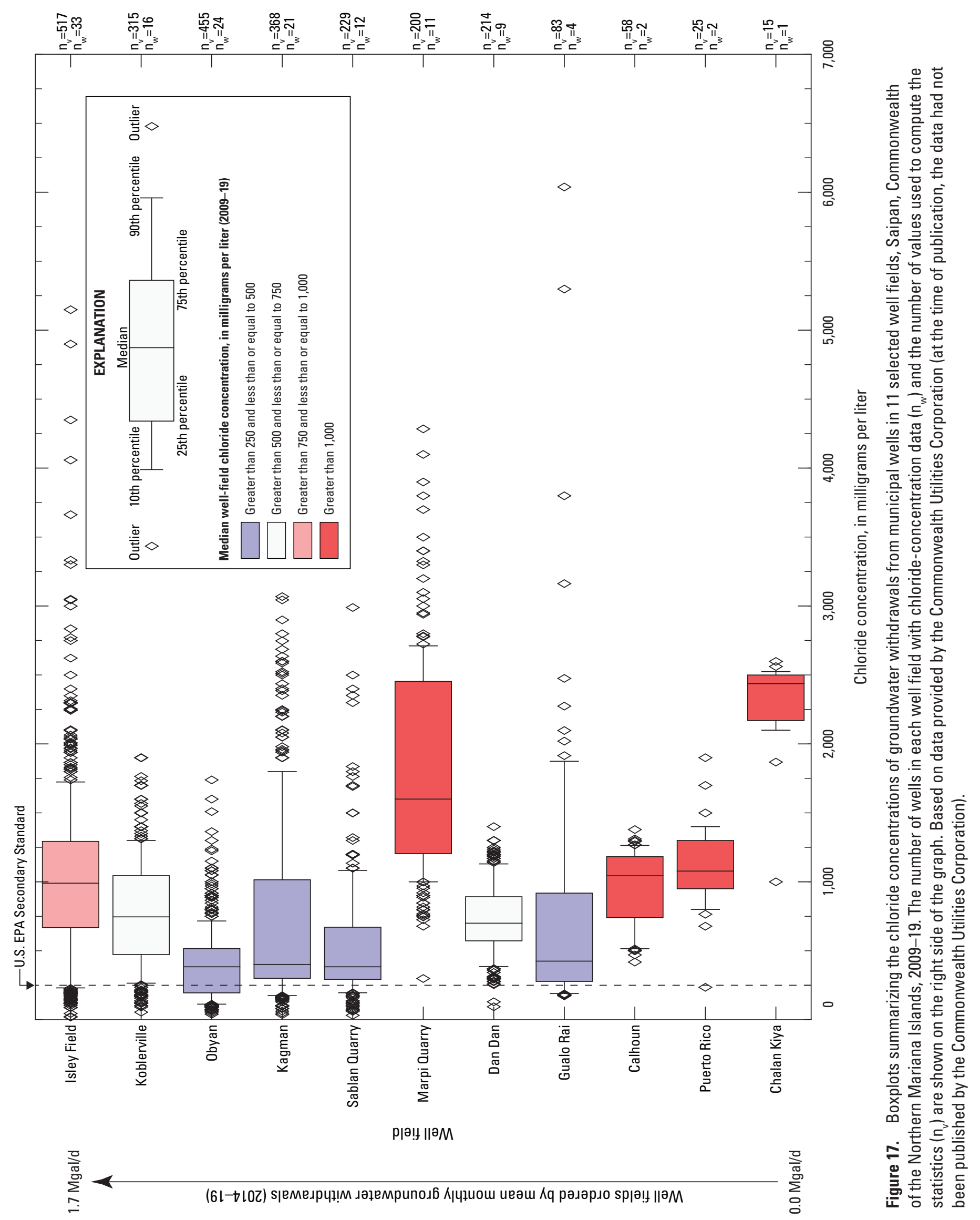




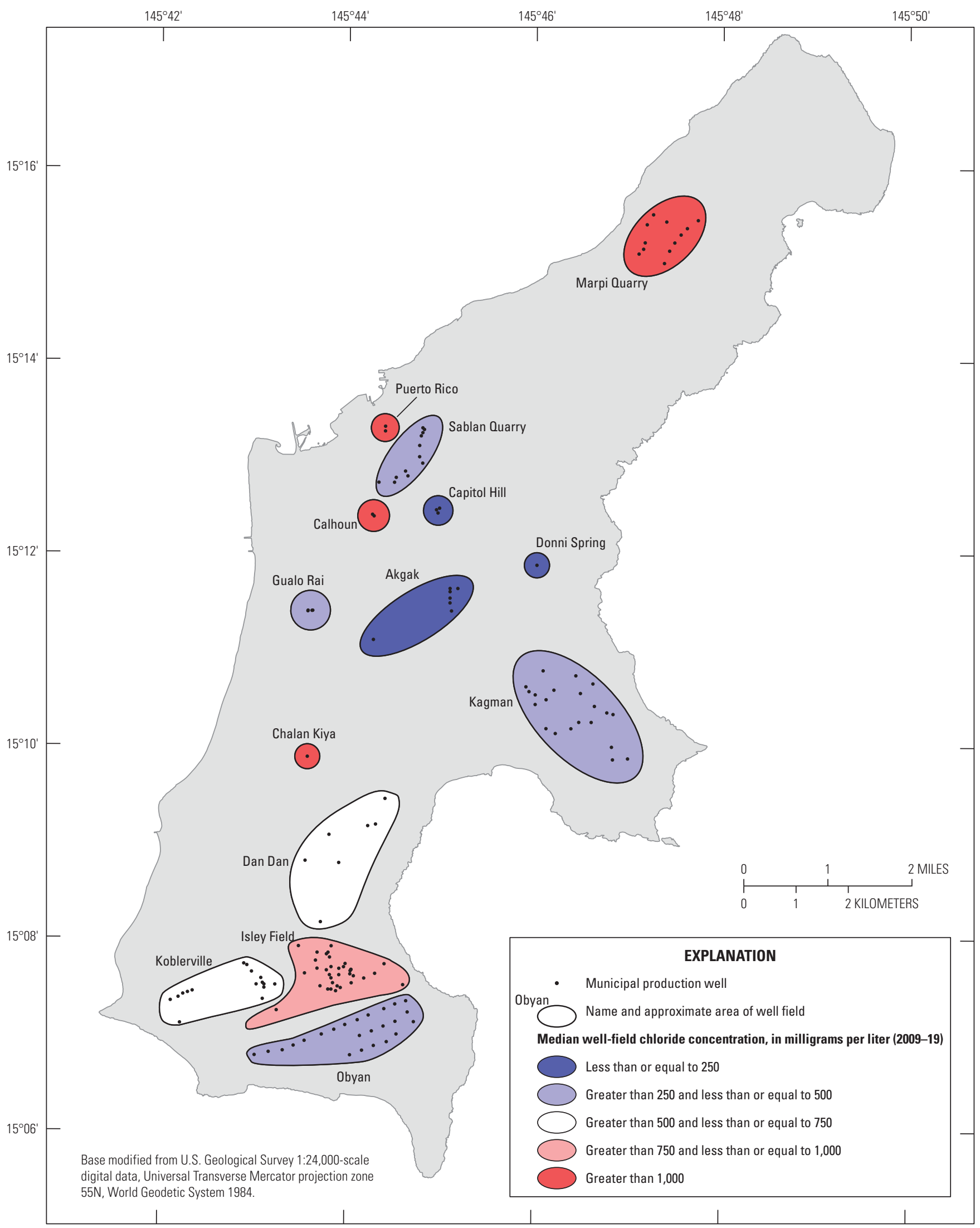

Figure 18. Map of median chloride concentrations for groundwater withdrawals from well fields on Saipan, Commonwealth of the Northern Mariana Islands, 2009-19. Based on data provided by the Commonwealth Utilities Corporation (at the time of publication, the data had not been published by the Commonwealth Utilities Corporation). 


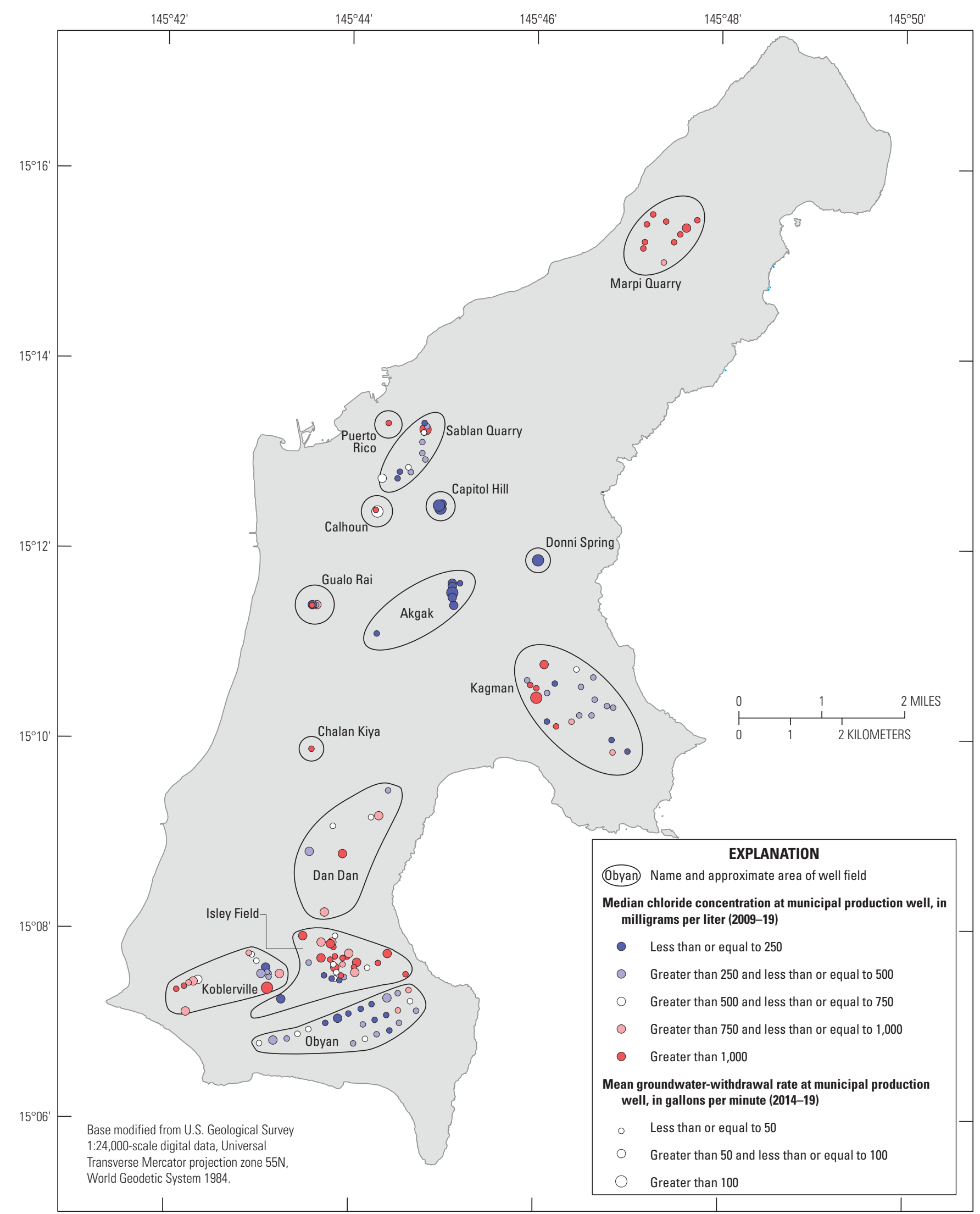

Figure 19. Map of median chloride concentrations during 2009-19 and mean groundwater-withdrawal rates during 2014-19 at municipal production wells, Saipan, Commonwealth of the Northern Mariana Islands. Based on data provided by the Commonwealth Utilities Corporation (at the time of publication, the data had not been published by the Commonwealth Utilities Corporation). 
and this spacing arrangement may help to reduce saltwater intrusion at the wells. In contrast, production wells in the Isley Field and Koblerville well fields are irregularly spaced and tend to be concentrated. Additionally, the Isley Field and Koblerville well fields have areas where production wells with relatively low median chloride concentrations are within short distances (less than $600 \mathrm{ft}$ ) of production wells with relatively high median chloride concentrations. An investigation of the causes of the spatial variability of median chloride concentrations for production wells on the southern plateau and elsewhere on Saipan, however, is not included in this report. It likely would require a comprehensive evaluation of several factors other than well-spacing arrangement and groundwater withdrawals, including (1) altitudes of well bottoms and screen intervals, (2) altitudes of pump intakes, (3) groundwater levels, (4) altitudes of the top and midpoint of the transition zone, and (5) hydrogeologic features in the aquifers.

The chloride concentrations of groundwater pumped by private production wells on Saipan are tested periodically by the BECQ. Chloride-concentration data during 2009-16 were provided by the BECQ (data after 2016 were not available) and indicate that most of the private production wells withdrew water with chloride concentrations exceeding $1,000 \mathrm{mg} / \mathrm{L}$ (at the time of publication, the data had not been published by the BECQ). The relatively high chloride concentrations of groundwater withdrawals from private production wells may be because (1) many of the private production wells are near the coastline of the western coastal plain where the freshwater lens generally is thinnest (figs. 8, 16), and (2) the bottoms of many private wells are below the freshwater lens.

\section{Trends in the Chloride Concentrations of Municipal Groundwater Withdrawals, 2009-19}

Trends in the chloride concentrations of groundwater withdrawn from each of Saipan's municipal production wells during December 2009-February 2019 were evaluated with the nonparametric Mann-Kendall test described by Helsel and Hirsch (2002) and Helsel and others (2005). The MannKendall test is a rank-based procedure that checks for monotonic increases (upward trend) or decreases (downward trend) in a variable, $y$, with respect to another variable, $x$. In general, a monotonic trend means that $y$ consistently increases or decreases as $x$ increases or decreases, although the trend does not have to be linear. For this analysis, $x$ represents time and $y$ represents chloride concentration. Trends were considered statistically significant for probability values ( $p$-values) less than or equal to 0.05 . The trend test has three possible outcomes:

(1) upward trend, (2) downward trend, or (3) no trend.

The results of the Mann-Kendall test indicate that the chloride concentrations of pumped groundwater had downward trends at 52 wells (36 percent of wells), upward trends at 9 wells ( 6 percent of wells), and no trends at 85 wells (58 percent of wells) (fig. 20). The well fields with the greatest groundwater withdrawals during 2014-19 (Isley Field, Koblerville, and Obyan), contain 33 wells with downward trends, one well with an upward trend (OB-12), and 39 wells with no trends. In contrast, the Kagman well field has one well with a downward trend (KG-3), four wells with upward trends (KG-10, KG-14, KG-19, and KG-21), and 16 wells with no trend.

The cause of the generally downward trends in chloride concentrations at municipal production wells during 2009-19 is uncertain and is not investigated in this report, but may be related to factors including (1) reductions in groundwater withdrawal rates at selected wells during 2009-19; (2) changes in pumping methods, such as switching to continuous pumping instead of intermittent pumping in which a pump is turned on and off to meet diurnal demands; and (3) raising the altitude of pump intakes.

For each well field, annual mean volume-weighted chloride concentrations during 2017-18 were determined (2014, 2015 , and 2016 were omitted because of incomplete withdrawal records) and compared with volume-weighted chloride concentrations determined for September-October 1998 (table 2).

The groundwater-withdrawal and chloride-concentration data for each well used to compute the mean volume-weighted chloride concentrations for September-October 1998 are from tables 3, 4, and 5 of Carruth (2000). Groundwater withdrawals during September-October 1998 were determined by multiplying an instantaneous meter reading at the well head in gallons per minute by 1,440 minutes per day; this method of estimating daily withdrawal is considered reasonable over short periods of time because all production wells were operated continuously (Carruth, 2000). Chloride concentrations during September-October 1998 were determined from one water sample that was generally, but not always, collected on the same day that the instantaneous groundwater-withdrawal determination was made. Therefore, mean volume-weighted chloride concentrations during September-October 1998 represent a general assessment of conditions during a two-month period, not two months of data. Some of the mean volumeweighted chloride concentrations for September-October 1998 reported here differ from those listed in table 6 of Carruth (2000) and table 1 of Carruth (2003) because of (1) minor changes in the well-field organization, and (2) minor corrections to calculations in Carruth (2000) and Carruth (2003).

For each well field, the mean volume-weighted chloride concentrations of groundwater withdrawals were determined for September-October 1998, 2017, and 2018 using equation 1:

$$
M_{f, t}=\frac{\sum_{w=1}^{j}\left(Q_{w, t} \times C_{w, t}\right)}{\sum_{w=1}^{j} Q_{w, t}}
$$

where

$$
\begin{gathered}
j \quad \begin{array}{l}
\text { is the number of wells in well field } f, \\
Q_{w, t} \quad \text { is the groundwater withdrawal from } \\
\text { production well } w \text { during period } t, \text { and }
\end{array} \\
C_{w, t} \quad \begin{array}{l}
\text { is the mean chloride concentration for well } w \\
\text { during period } t .
\end{array}
\end{gathered}
$$

The time period $(t)$ was a year for 2017 and 2018 and was two months (September-October) for 1998. Groundwater withdrawals from production wells $\left(Q_{w, t}\right)$ for 2017 and 2018 were the mean value of the monthly withdrawals during the 


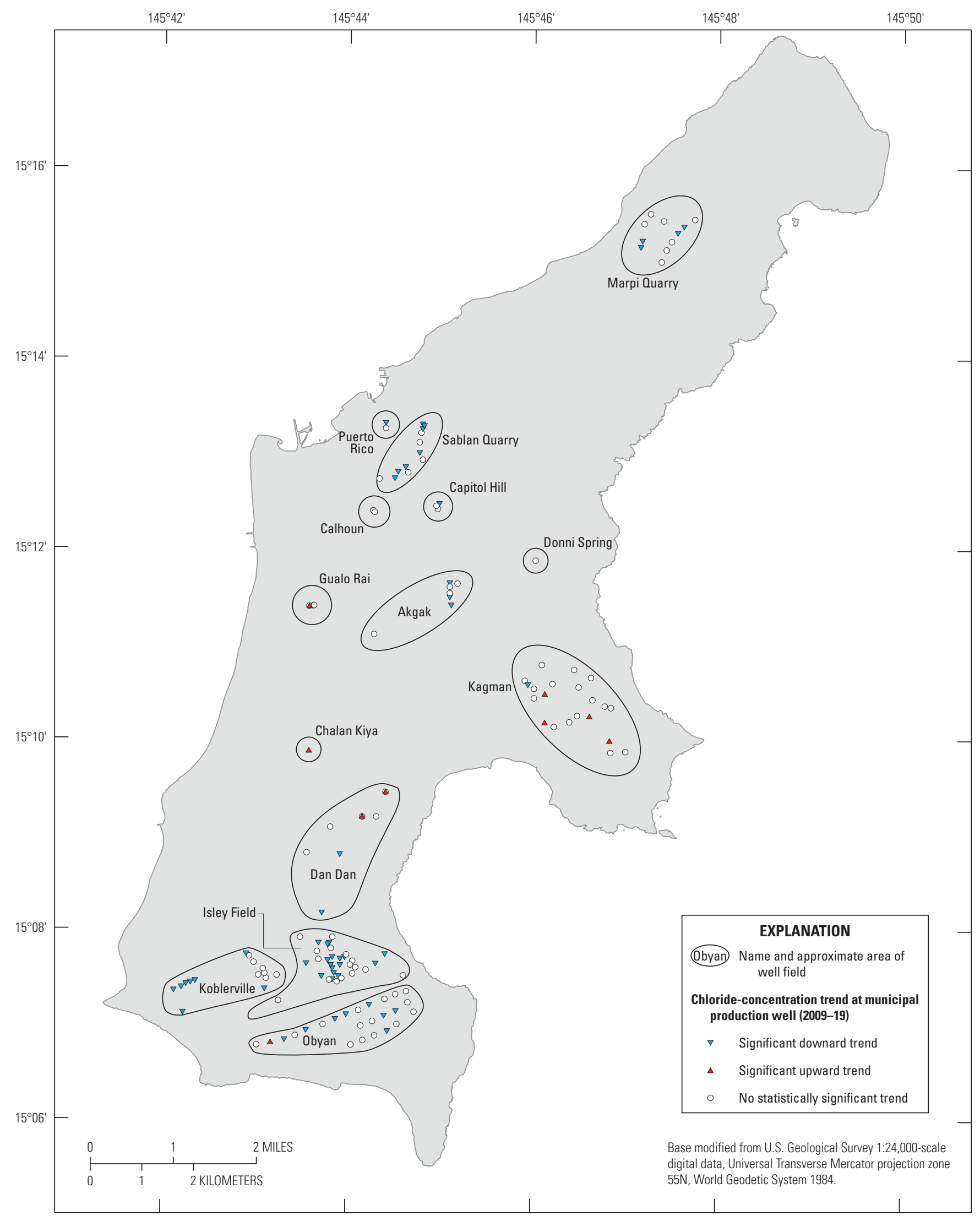

Figure 20. Mapped results of Mann-Kendall test for monotonic trends in the chloride concentrations of groundwater withdrawals from municipal production wells, Saipan, Commonwealth of the Northern Mariana Islands, 2009-19. Statistical significance is based on p-values less than or equal to 0.05 . Data tested were provided by the Commonwealth Utilities Corporation (at the time of publication, the data had not been published by the Commonwealth Utilities Corporation). 


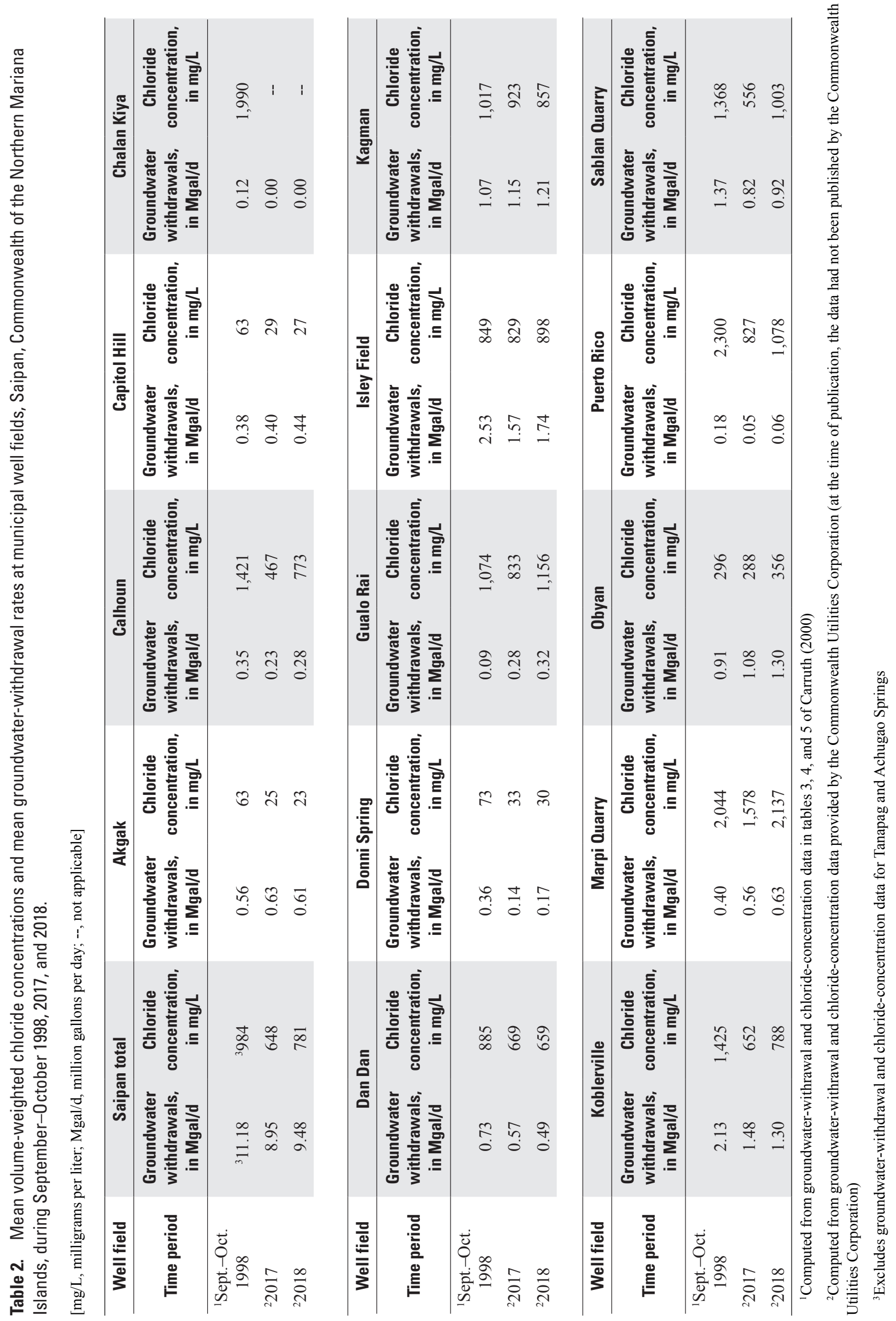


year, weighted for the number of days in each month. Groundwater withdrawals from well fields for September-October 1998, 2017, and 2018 were computed by summing the mean withdrawals from wells $\left(Q_{w, t}\right)$ in the well field during the time period. The mean chloride concentration at each well $\left(C_{w, t}\right)$ was determined by averaging the chloride-concentration measurements collected during the time period. In general, two chloride-concentration measurements were collected at each well per year during 2017-18.

For September-October 1998, 2017, and 2018, the mean volume-weighted chloride concentration for groundwater withdrawals on Saipan was calculated using equation 2:

$$
M_{t}=\frac{\sum_{f=1}^{k}\left(M_{f, t} \times Q_{f, t}\right)}{\sum_{f=1}^{k} Q_{f, t}}
$$

where

$$
\begin{gathered}
M_{t} \quad \begin{array}{l}
\text { is the mean volume-weighted chloride } \\
\text { concentration for Saipan during period } t,
\end{array} \\
M_{f, t} \quad \begin{array}{l}
\text { is the mean volume-weighted chloride } \\
\text { concentration for well field } f \text { during period } \\
t, \text { and }
\end{array} \\
k \quad \text { is the number of well fields of Saipan. }
\end{gathered}
$$

Mean volume-weighted chloride concentrations represent the mean chloride concentration for a given amount of pumped water and can be used to compare conditions between well fields while accounting for differences in groundwater withdrawals. That is, chloride-concentration measurements from wells (or well fields) that have relatively high withdrawals are weighted more than chloride-concentration measurements from wells (or well fields) that have relatively low withdrawals.

Withdrawals and volume-weighted chloride concentrations in most well fields and island-wide were greater in September-October 1998 than 2017-18. The volume-weighted chloride concentrations in 1998 may be elevated relative to adjacent years because 1998 was the largest drought on record (fig. 4). Unfortunately, September-October 1998 represents the only period in which concurrent chloride-concentration and groundwater-withdrawal data are available at all municipal wells prior to 2014 .

\section{Relation Between Chloride Concentration and Specific Conductance in Groundwater}

The CUC also measured the specific conductance of a subset (about 1,900) of the about 2,700 groundwater samples collected during 2009-19 from which chloride concentration was determined. Specific conductance was determined using a calibrated field meter (Heidi Yelin, CUC, oral commun., 2019). Results for the subset of samples were examined to define a regression relating specific conductance to chloride concentration for groundwater samples on Saipan. This regression was needed because (1) specific conductance sometimes is measured instead of chloride concentration to assess groundwater salinity, and (2) there is not a U.S. EPA secondary standard for the specific conductance of drinking water.

A linear regression was performed on the chloride-concentration and specific-conductance data for the about 1,400 samples with chloride concentrations less than $1,000 \mathrm{mg} / \mathrm{L}$ (fig. 21). The regression was limited to samples with chloride concentrations less than $1,000 \mathrm{mg} / \mathrm{L}$ to improve the accuracy of the regression for low-salinity groundwater samples. The linear regression $\left(\mathrm{R}^{2}=0.943\right)$ indicates that a chloride concentration of $250 \mathrm{mg} / \mathrm{L}$ is approximately equal to a specific conductance of $1,372 \mu \mathrm{S} / \mathrm{cm}$ for groundwater in Saipan:

$$
y=3.36 x+532
$$

where

$y \quad$ is specific conductance, in microsiemens per centimeter at 25 degrees Celsius, and

$x \quad$ is chloride concentration, in milligrams per liter.

The specific-conductance value of $1,372 \mu \mathrm{S} / \mathrm{cm}$ will be rounded to $1,400 \mu \mathrm{S} / \mathrm{cm}$ for simplicity. Therefore, groundwater with a specific conductance less than or equal to $1,400 \mu \mathrm{S} / \mathrm{cm}$ also is considered freshwater for this report.

\section{Salinity Profiles}

Salinity profiles show the vertical distribution of specific conductance in a monitor well. Salinity profiles can be used to estimate the thickness of a freshwater lens in a coastal aquifer (see for example Meyer and Presley, 2001; Oki, 2005; Oki, 2006; Gingerich, 2013). Because the amount of water that can be withdrawn from a freshwater-lens system is limited by the salinity of the water (among other factors), the thickness of the freshwater lens and the altitudes of the top and midpoint of the transition zone are relevant for water-resource management.

Conductivity, temperature, and depth (in terms of pressure) profiles, hereinafter "salinity profiles," were measured during 2018-19 at 12 selected monitor wells (fig. 22) on Saipan. No salinity profiles were collected at monitor well KV-MW1 because its borehole was determined to be obstructed above the water table during a site visit in July 2018. Also, no salinity profiles were collected at monitor well AG-MW1 because it is drilled into a high-level aquifer containing only freshwater (Carruth, 2003). During July-August 2018, one salinity profile was measured in each of the 12 selected monitor wells. During March 2019, one salinity profile was measured in five monitor wells (OB-MW1, IF-MW2, IF-MW4, KG-MW3, and AM-MW1b), and two consecutive salinity profiles were measured in one monitor well (STMW1). A salinity profile could not be collected at DD-MW1 during March 2019 because the borehole was obstructed above the water table. Salinity profiles measured in July-August 2018 represent groundwater conditions at the beginning of the wet season (July to November). The second set of salinity profiles were planned for January 2019 to capture the 


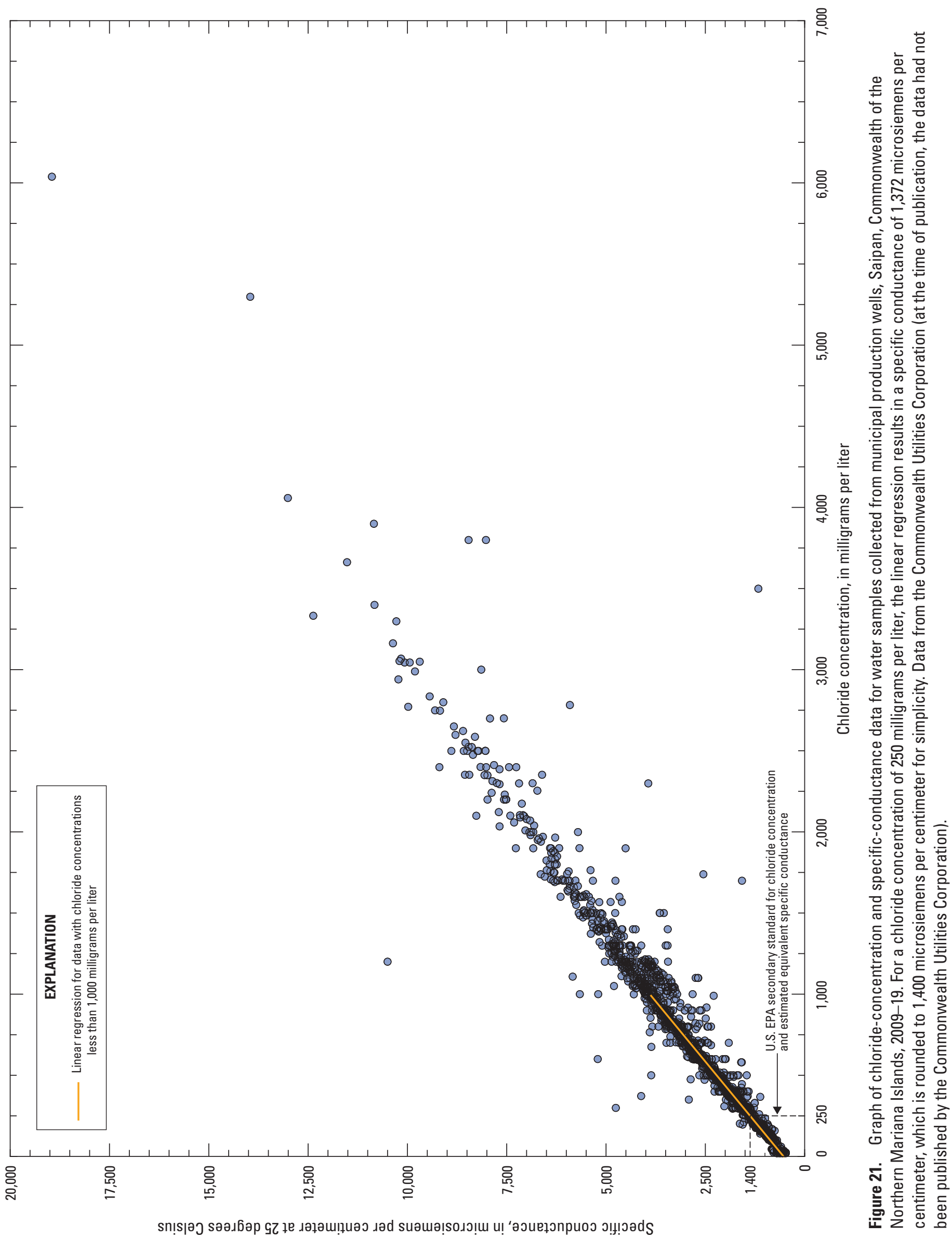


groundwater conditions at the end of the wet season; however, the trip was delayed until early March, about 3 months into the dry season (December to June).

The salinity profiles were collected by lowering an oceanographic probe through the monitoring wells while recording data at 1-second intervals (fig. 22). In some cases, the monitoring wells were shallow (IF-MW5) or obstructed (IF-MW1, IF-MW3, and DD-MW1), resulting in profiles that are considerably shorter than the profiles at other wells. The salinity-profile measurements were processed using a consistent method. Details of the processing method, as well as the raw and processed salinity-profile measurements, are contained in each salinity profile's GeoLog file, which can be accessed at the USGS GeoLog database (https://webapps.usgs. gov/GeoLogLocator/\#!/) using the monitor well's USGS site number (table 1). The temperature data from the salinity profiles are not discussed in this report, although they were used to determine the specific conductance.

Consecutive salinity profiles were measured at monitor well ST-MW1 on March 9, 2019 and are designated as "09-Mar-2019a" and "09-Mar-2019b," in figure 22K. The consecutive profiles were conducted to assess the repeatability of the salinity-profile methods (fig. $22 K$; table 3 ). The profiles are nearly identical, and this suggests that the salinity-profilemeasurement method and processing method used during 2018-19 produce consistent results and that the water column is not substantially disturbed by the movement of the probe down and up the well.

The vertical distribution of salinity was also measured in six monitor wells (IF-MW2, OB-MW1, KV-MW1, DD-MW1, KG-MW3, and ST-MW1) during 1998-99. The measurement method during 1998-99, however, involved the use of a pointsampling bailer that collected water samples at discrete depths throughout the water column in the wells (Carruth, 2003). The chloride concentration of each sample was determined by the CUC laboratory. Vertical profiles of the chloride concentrations in the six monitor wells are shown in Carruth (2003; fig. 8).

Comparisons between the 1998-99 data and the 2018-19 data were not made in this report because of (1) differences in methods, and (2) uncertainty regarding the 1998-99 data. Water samples were collected during 1998-99 using a ball-valve bailer, which may not seal completely during sample retrieval upward through the water column. Because water samples from 1998-99 may have been affected by water inflow to an incompletely sealed bailer from depths above the sampling depth, the samples may not be representative of water at the originally sampled depths and therefore are difficult to interpret.

\section{Limitations of Salinity Profiles}

Salinity profiles from open boreholes may be affected by vertical flow of groundwater within the borehole (Paillet and others, 2002; Rotzoll, 2010; Rotzoll, 2012). Vertical borehole flow can occur because of both natural and withdrawal-induced vertical differences in hydraulic head (the height above a specified datum at which the water rises in a piezometer that is open at a particular depth). Downward flow of freshwater can occur in recharge areas where head decreases with depth, resulting in an overestimate of freshwater-lens thickness based on salinity profiles. Upward flow of saltwater can occur near coastal discharge areas and near production wells where head increases with depth, resulting in an underestimate of freshwater-lens thickness based on salinity profiles.

Monitor wells whose salinity profiles show step-like changes in specific conductance with depth may have borehole flow (Rotzoll, 2010). Salinity profiles for ST-MW1 on Saipan show step-like changes in specific conductance (fig. $22 K$ ), which is consistent with borehole flow. For wells with borehole flow, the estimated altitudes of the top of the transition zone may not accurately reflect conditions in the aquifer, and therefore estimates of the thickness of the freshwater lens may not be accurate. Rotzoll (2010) analyzed salinity profiles from deep monitor wells in Hawai' $i$ and found that the midpoint of the transition zone (estimated from the profiles) may be less affected by borehole flow than the top of the transition zone and indicated that the midpoint of the transition zone may be a better proxy than the top of the transition zone for evaluating changes in freshwater-lens thickness over time.

\section{Characteristics of the Freshwater-Lens System}

Salinity profiles and water-level measurements in monitor wells during 2018-19 were used to determine the altitudes of (1) the water level, (2) the top of the transition zone, and (3) the midpoint of the transition zone within each monitor well. The altitudes of the top and midpoint of the transition zone in a freshwater-lens system can be used as metrics for freshwater availability (see for example Rotzoll, 2010; Gingerich and Engott, 2012; Gingerich, 2013).

Groundwater is considered fresh if its specific conductance is less than or equal to $1,400 \mu \mathrm{S} / \mathrm{cm}$ (see Relation Between Chloride Concentration and Specific Conductance for more information). Therefore, using the specific-conductance data from the salinity profiles, the altitude of the top of the transition zone was set to the altitude of the first (uppermost) specific-conductance measurement that exceeded 1,400 $\mu \mathrm{S} /$ $\mathrm{cm}$ (figs. 8 and 22), if the overlying specific-conductance measurements were below $1,400 \mu \mathrm{S} / \mathrm{cm}$. The altitude of the midpoint of the transition zone is defined as the altitude at which the specific conductance of groundwater is 25,000 $\mu \mathrm{S} / \mathrm{cm}$, which is 50 percent of the approximate specific conductance of saltwater, $50,000 \mu \mathrm{S} / \mathrm{cm}(\mathrm{Hem}, 1985$, p. 69) (fig. 8). A specific conductance of $50,000 \mu \mathrm{S} / \mathrm{cm}$ is commonly used for saltwater on Pacific islands (see for example Oki, 2005, 2006; Gingerich and Engott, 2012) and is near the maximum value measured in monitor wells on Saipan (fig. 22), although the specific conductance of groundwater can exceed 50,000 $\mu \mathrm{S} / \mathrm{cm}$ in some cases (Hem, 1985). Salinity 
profiles at six of the monitor wells (OB-MW1, IF-MW2, IF-MW4, KG-MW3, ST-MW1, and AM-MW1b) indicate that the wells extend into and through the transition zone of the freshwater-lens system - that is, the specific-conductance measurements at the bottom of the well are near the assumed specific conductance of saltwater $(50,000 \mu \mathrm{S} / \mathrm{cm})$.

The thickness of the freshwater lens was computed for each salinity profile collected during 2018-19 for all monitor wells, except KG-MW1 and KG-MW2 (table 3). The thickness of the freshwater lens was not determined for KG-MW1 and KG-MW2 because the specific-conductance measurements in these wells did not exceed $1,400 \mu \mathrm{S} / \mathrm{cm}$. For each profile without any measured freshwater (that is, all specific-conductance measurements exceeded 1,400 $\mu \mathrm{S} / \mathrm{cm}$ ), the freshwater-lens thickness was assumed to be $0 \mathrm{ft}$. For each remaining profile, the thickness of the freshwater lens was computed as the difference between the altitude of the water level and the altitude of the top of the transition zone.

The altitudes of the top and midpoint of the transition zone were determined to the nearest hundredth of a foot and rounded to the nearest foot in table 3 . Computations of freshwater-lens thickness used the unrounded value for the altitude of the top of the transition zone. Freshwater-lens thickness was greatest (46 ft) at DD-MW1 and was least (0 ft) at IF-MW1 and IF-MW4, in which all specific-conductance measurements exceeded the freshwater threshold $(1,400 \mu \mathrm{S} / \mathrm{cm})$.

The midpoint of the transition zone was not encountered in (1) the shallowest monitor well (IF-MW5), whose bottom is about $20 \mathrm{ft}$ below NMVD03, (2) three monitor wells that were obstructed above their drilled depths (IF-MW1, IF-MW3, and DD-MW1), and (3) in two monitor wells (KG-MW1 and KG-MW2) in which only freshwater exists because the wells are likely in a confined groundwater setting. The altitude of the midpoint of the transition zone at DD-MW1, however, where the highest specific-conductance value was about $22,000 \mu \mathrm{S} / \mathrm{cm}$, was estimated by linearly extrapolating the bottom $5 \mathrm{ft}$ of the profile downward, resulting in an altitude of $52 \mathrm{ft}$ below NMVD03. In the monitor wells where the altitude of the midpoint of the transition zone was measured or was estimated, the altitudes ranged from about -23 to $-52 \mathrm{ft}$ relative to NMVD03.

\section{A. Obyan Monitor Well 1 (OB-MW1)}

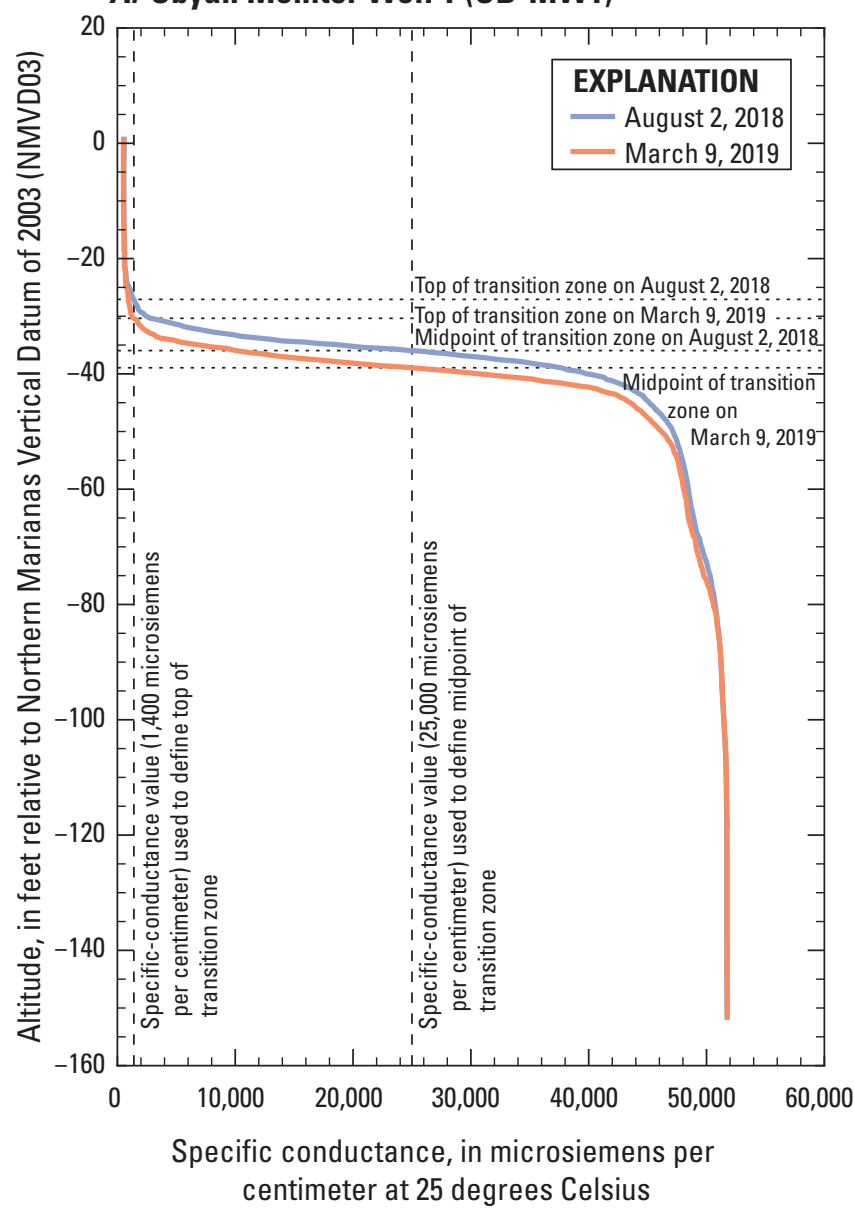

\section{B. Isley Field Monitor Well 1 (IF-MW1)}

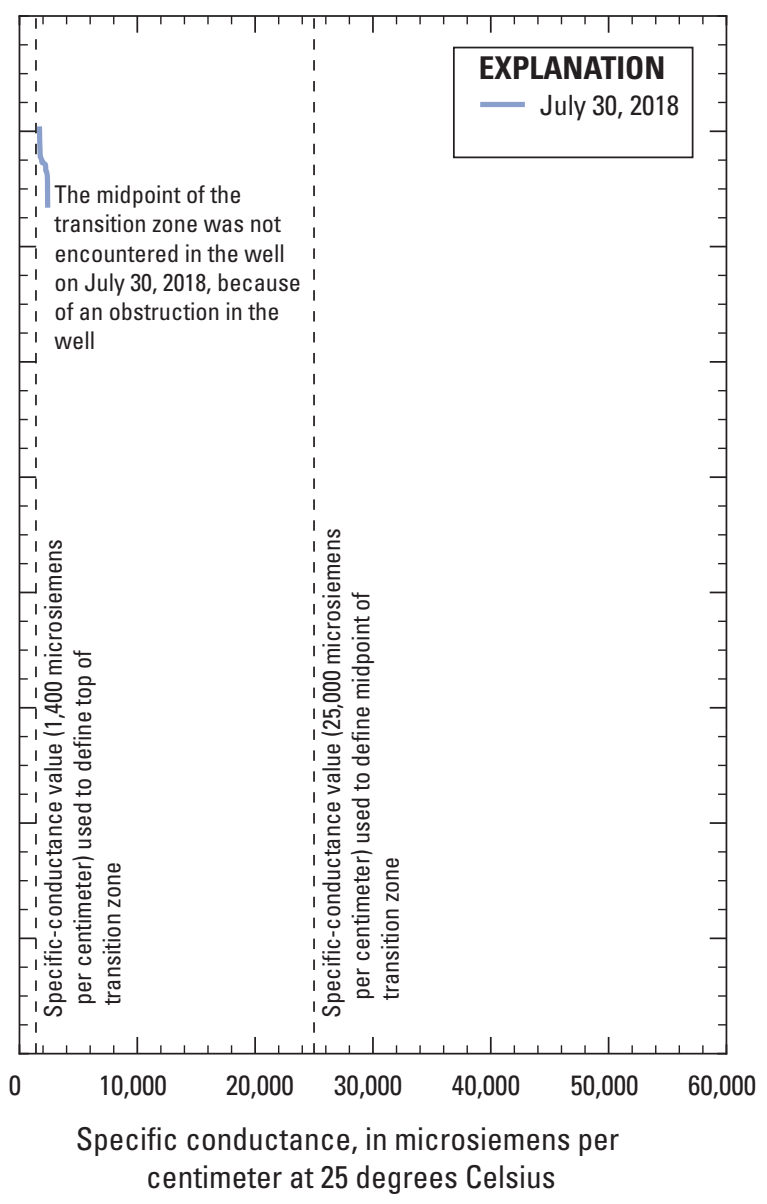

Figure 22 (pages 37-40). Graph of salinity profiles in selected monitor wells on Saipan, Commonwealth of the Northern Mariana Islands. 
C. Isley Field Monitor Well 2 (IF-MW2)

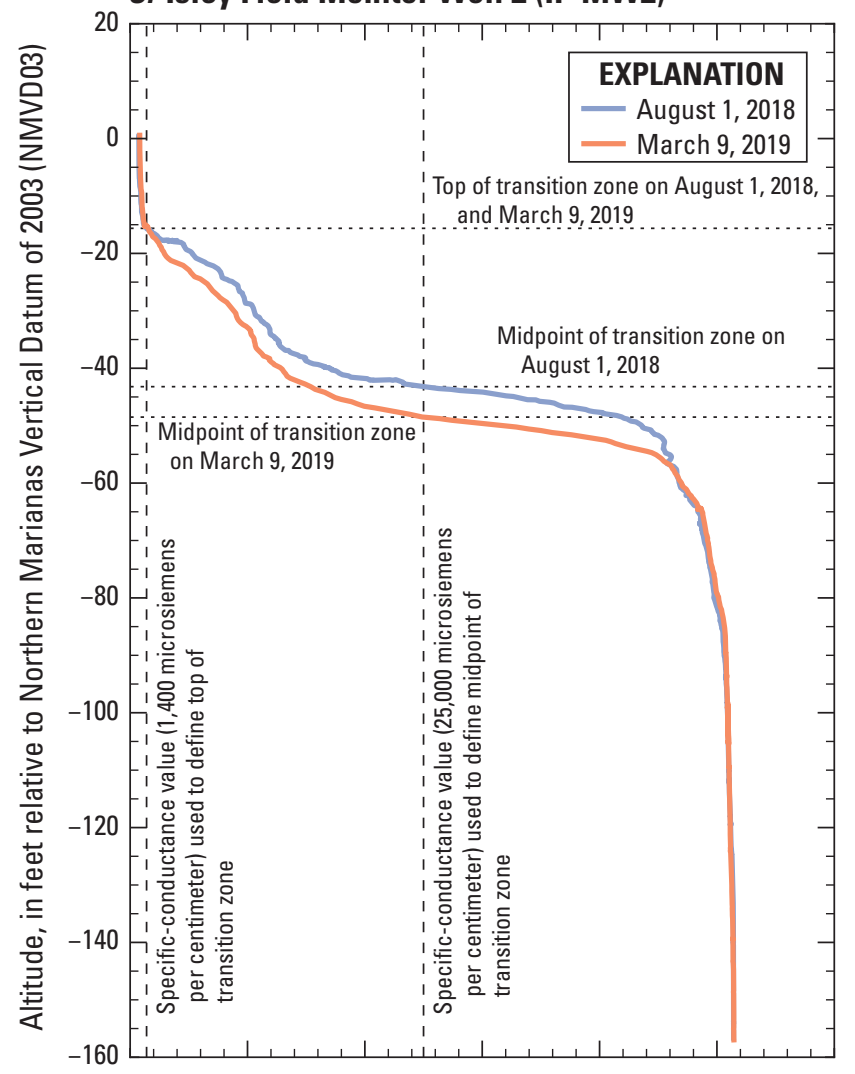

E. Isley Field Monitor Well 4 (IF-MW4)

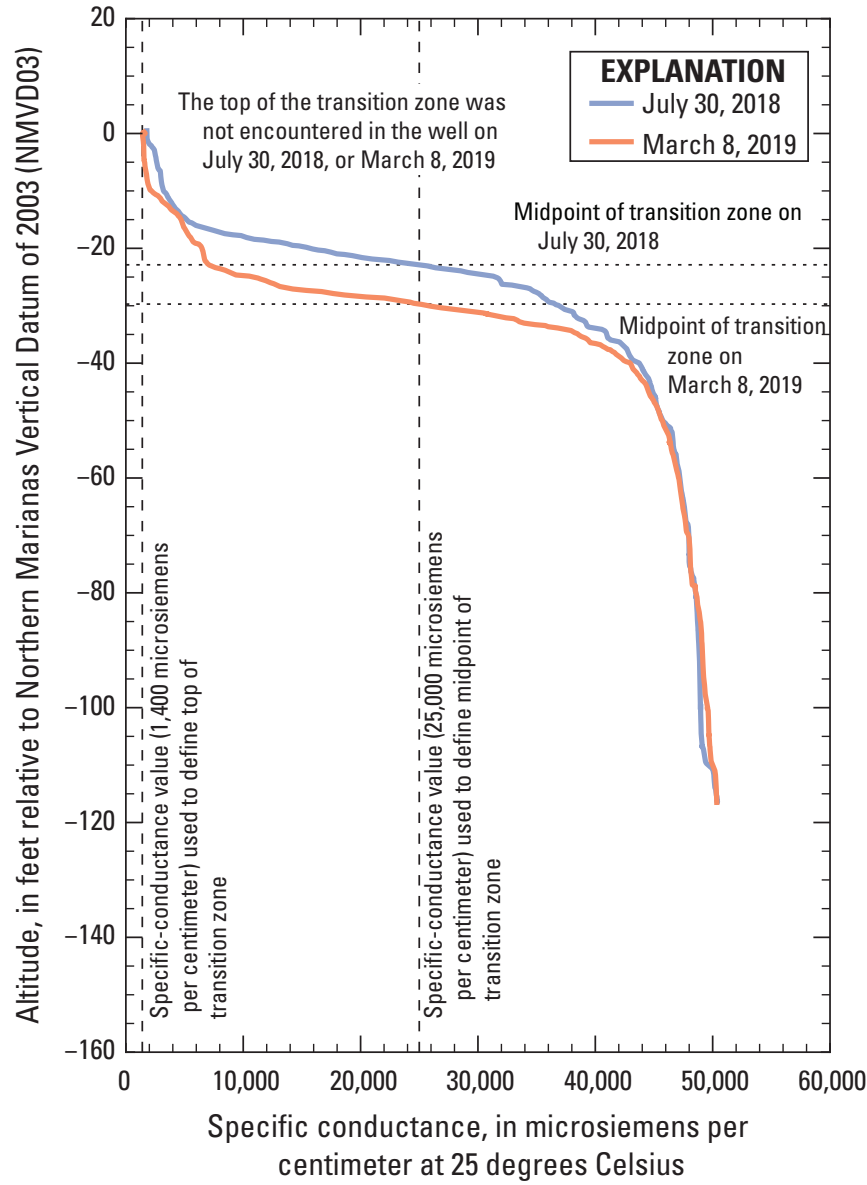

D. Isley Field Monitor Well 3 (IF-MW3)

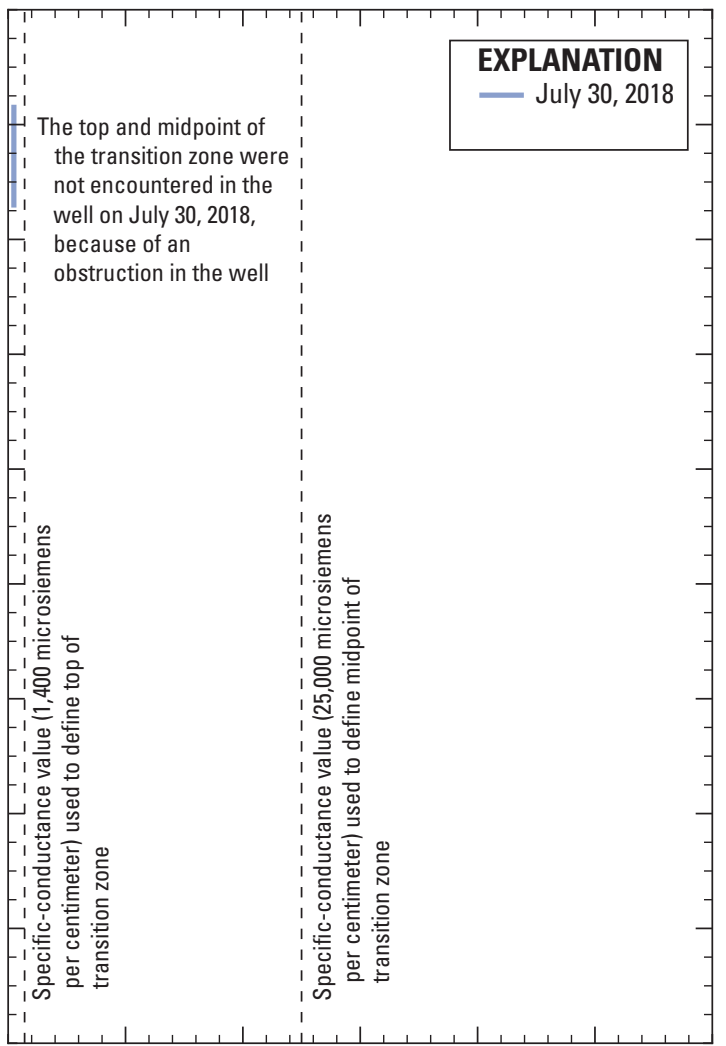

F. Isley Field Monitor Well 5 (IF-MW5)

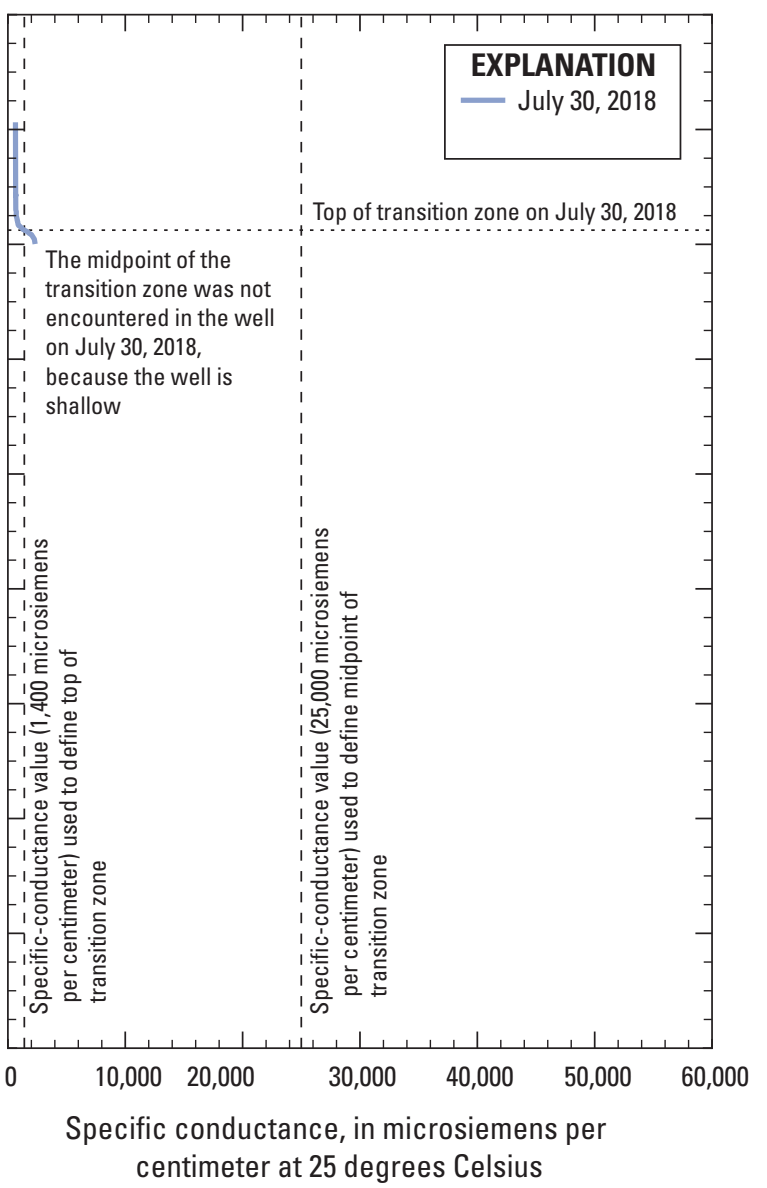

Figure 22 (pages 37-40).-Continued 


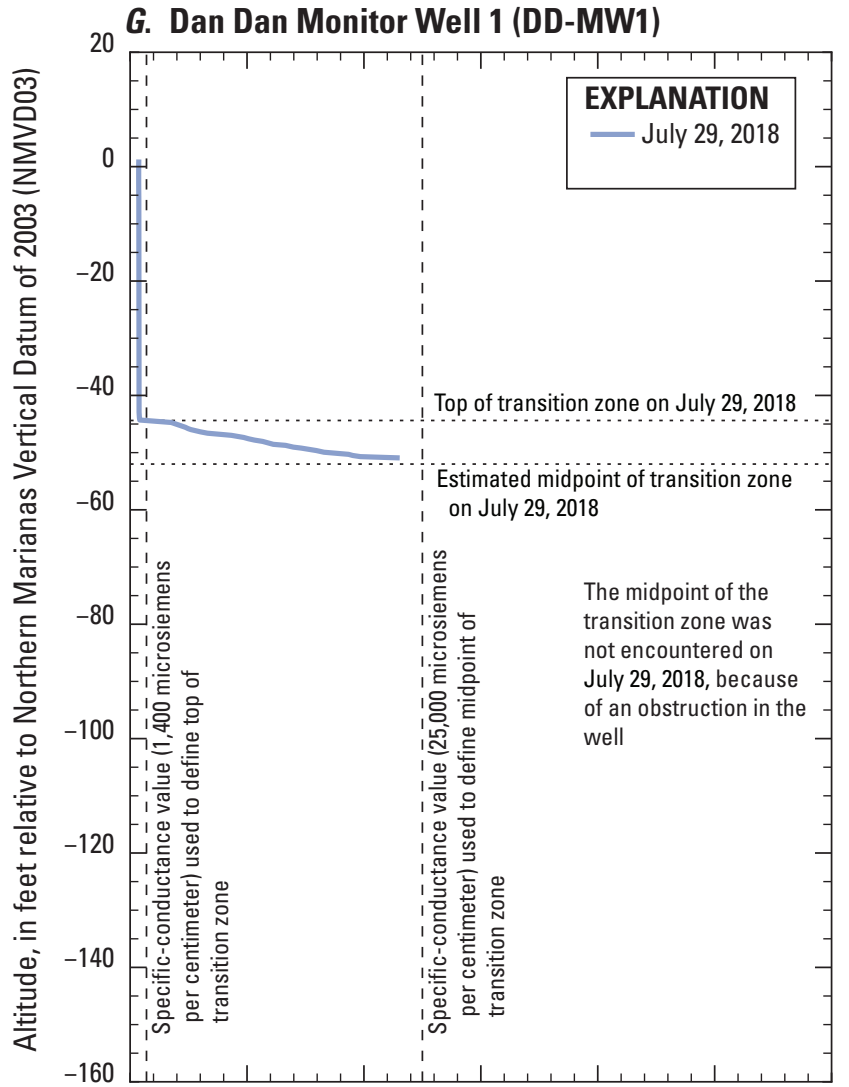

I. Kagman Monitor Well 1 (KG-MW1)

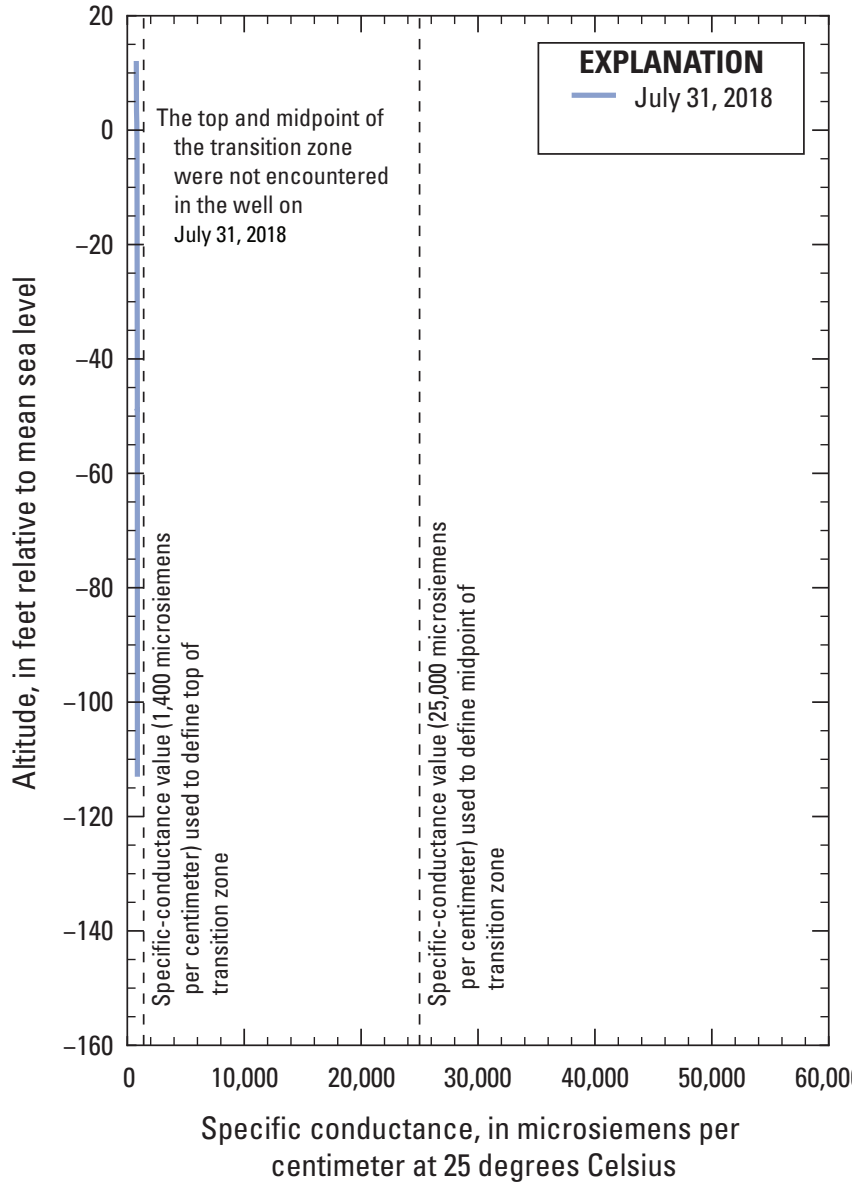

Figure 22 (pages 37-40).-Continued
H. Kagman Monitor Well 3 (KG-MW3)

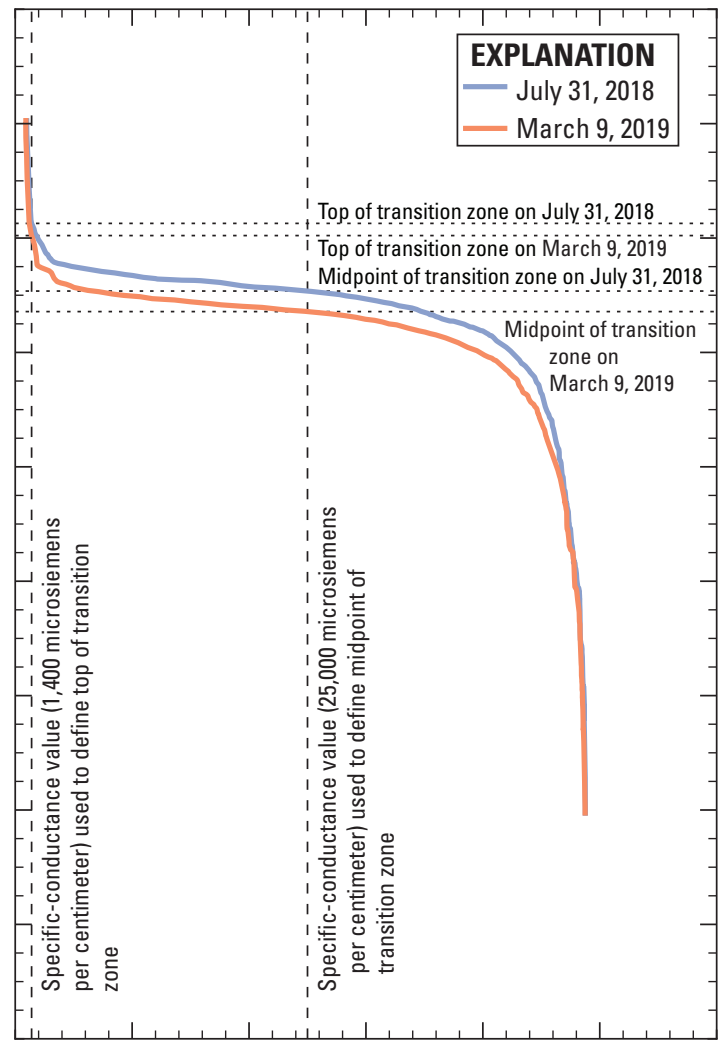

\section{J. Kagman Monitor Well 2 (KG-MW2)}

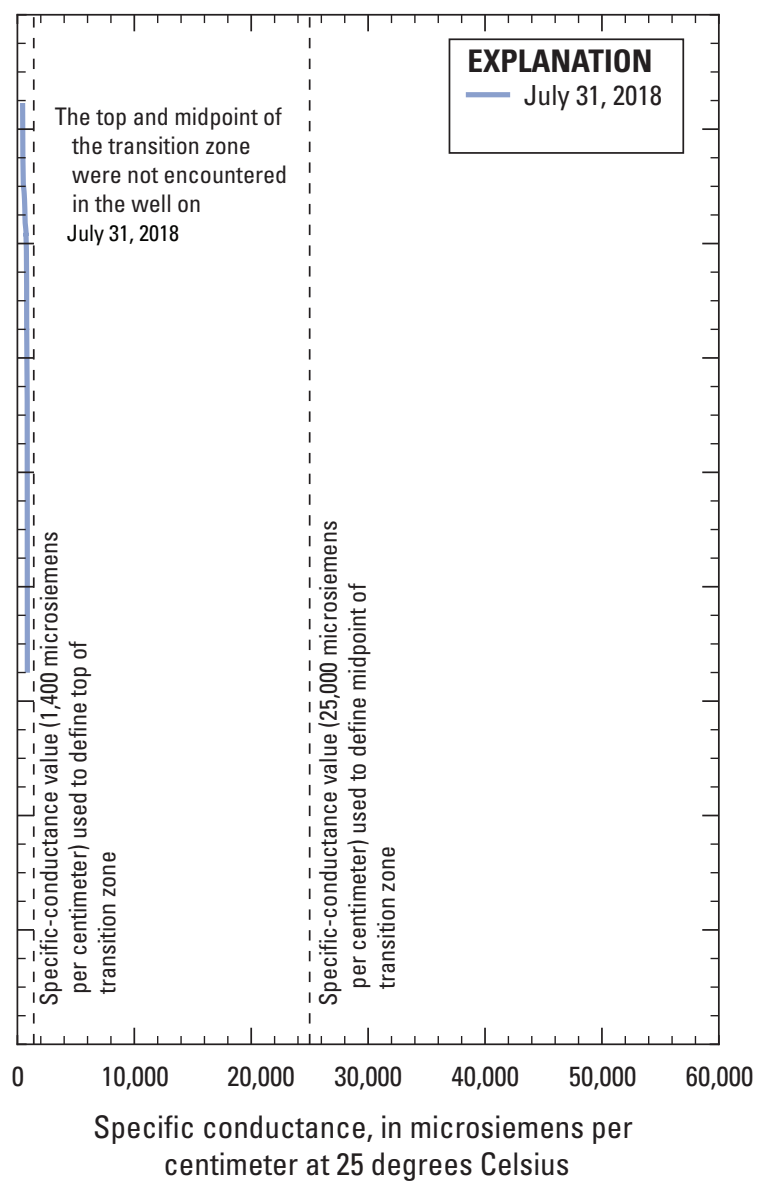




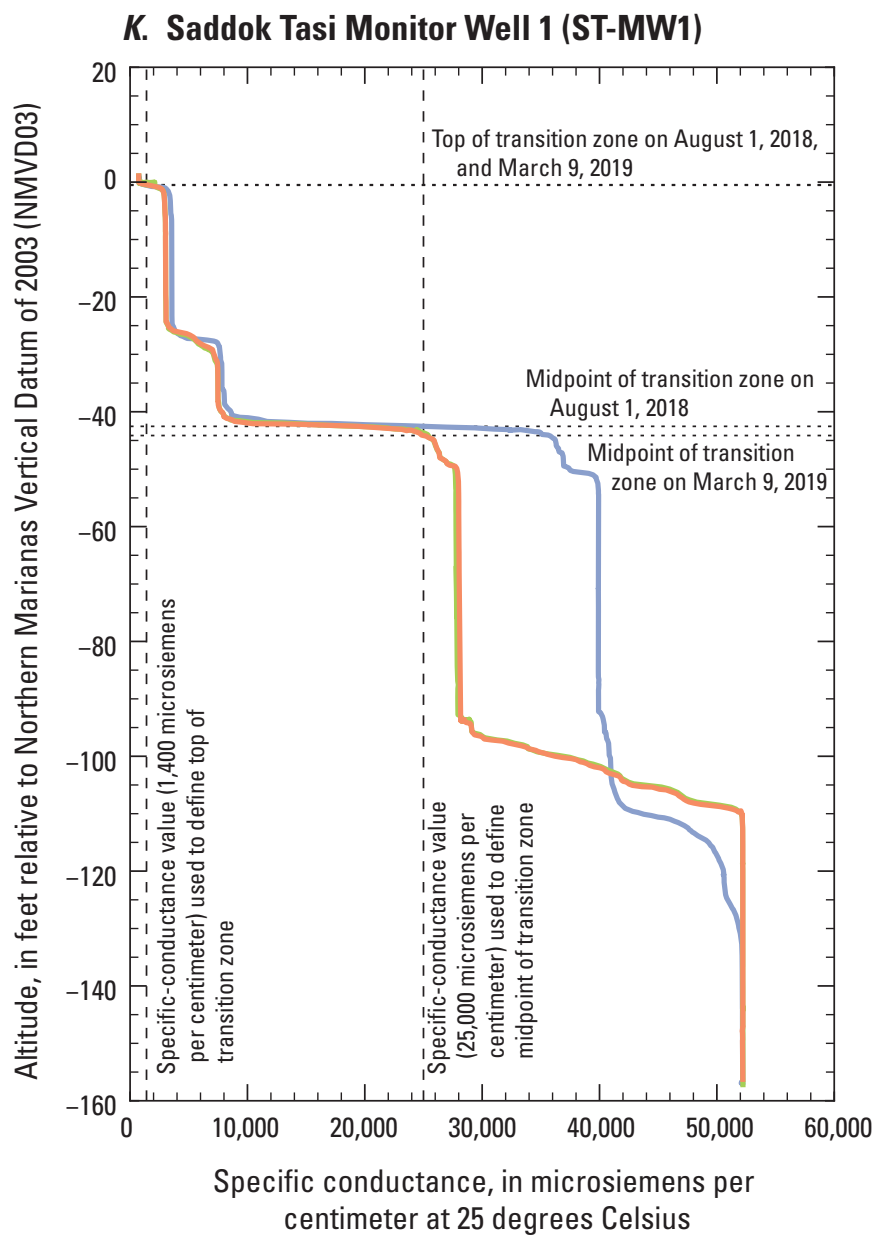

EXPLANATION

- August 1, 2018 - March 9, 2019a March 9, 2019b

\section{As Matuis Monitor Well 1b (AM-MW1b)}

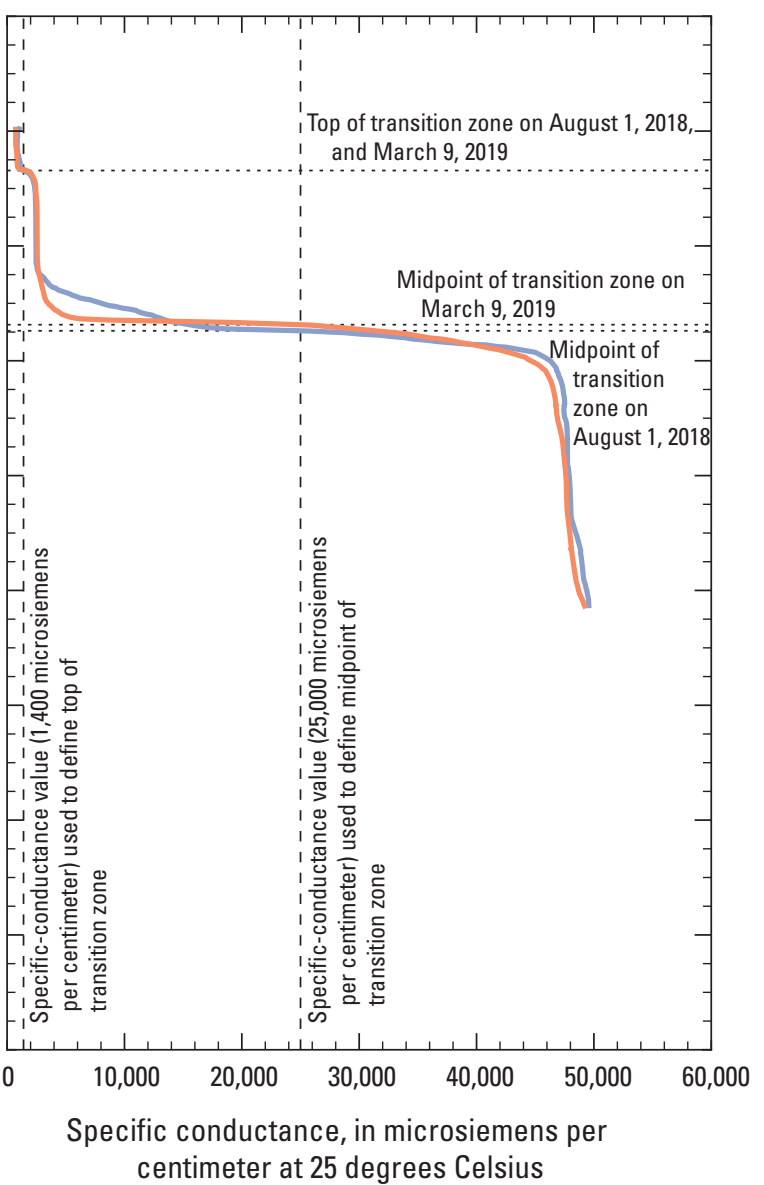

EXPLANATION

- August 1, 2018 March 9, 2019

Figure 22 (pages 37-40). - Continued 


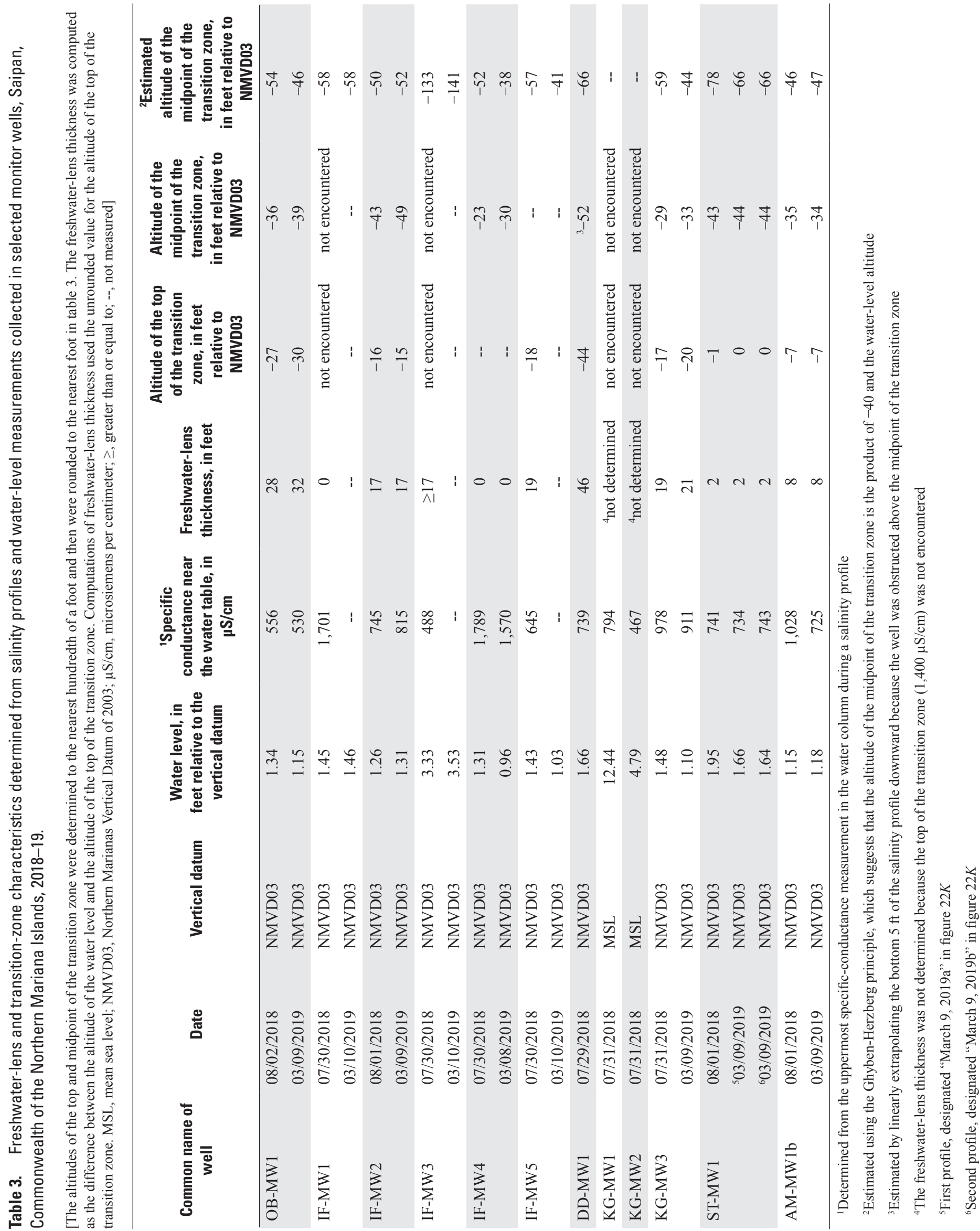




\section{Southern Saipan}

In the southern plateau, the measured thickness of the freshwater lens was greatest (46 ft) at DD-MW1, despite DD-MW1 being relatively close to the coast (fig. 23), where a generalized freshwater lens would be thinnest (fig. 8). Monitor well DD-MW1 is about 2,100 ft from the nearest production well and may not be affected by saltwater upconing induced by groundwater withdrawals, which may contribute to the relatively thick freshwater lens.

In the three southernmost well fields (Isley Field, Koblerville, and Obyan), the freshwater lens was thickest at OB-MW1 (28-32 ft). Monitor well OB-MW1 is in the Obyan well field, which was the well field with the lowest median chloride concentration of groundwater withdrawn from municipal production wells during 2009-19 (figs. 17 and 23). The thickness of the freshwater lens ranged from $0 \mathrm{ft}$ to greater than $17 \mathrm{ft}$ in the five Isley Field monitor wells. The thickness of the freshwater lens was not determined for the only monitor well (KV-MW1) in the Koblerville well field because an obstruction above the water table in the well's borehole during 2018-19 precluded a measurement.

Within Isley Field, the two monitor wells without any freshwater, IF-MW1 and IF-MW4, are near (within $300 \mathrm{ft}$ of) production wells with high median chloride concentrations (greater than $750 \mathrm{mg} / \mathrm{L}$ ). Furthermore, IF-MW4 is close to the coast and is on the east (seaward) side of the Dago fault, a potential hydrologic barrier, and groundwater near IF-MW4 may have more tide-induced mixing of freshwater and saltwater than in monitor wells west of the fault. Salinity profiles from IF-MW1 and IF-MW4, however, did indicate several feet of relatively fresh water (that is, less than $2,000 \mu \mathrm{S} / \mathrm{cm}$ ) (figs. 22B, 22E). Wells IF-MW2, IF-MW3, and IF-MW5 had at least $17 \mathrm{ft}$ of freshwater.

Salinity-profile measurements from IF-MW3 on July 30, 2018, indicated $17 \mathrm{ft}$ of freshwater above an obstruction in the well's borehole (fig. 22D). Because specific conductance did not increase with depth in the water column above the obstruction, the thickness of the freshwater lens was reported as at least $17 \mathrm{ft}$ (table 3). Additionally, water levels measured in IF-MW3 on July 30, 2018, were about $2 \mathrm{ft}$ higher than those measured at all remaining monitor wells in the southern plateau on the same or following three days (table 3). Relatively highwater levels at IF-MW3 also were measured during 1997-2005 (U.S. Geological Survey, 2019). The cause of the relatively high-water levels at IF-MW3 is unknown but could be due to the presence of a low-permeability feature in the subsurface near IF-MW3. Because freshwater-lens thickness is related to water-level altitude (see an explanation of the Ghyben-Herzberg principle in Freshwater Lens), the elevated water levels at IF-MW3 indicate that the well may be penetrating a thick part of the freshwater lens in the Isley Field well field.

The distance between the top and midpoint of the transition zone at IF-MW2 (about 27-34 ft; fig. 22C) is about three times as great as the distance between the top and midpoint of the transition zone at OB-MW1 (about $9 \mathrm{ft}$; fig. 22A). The relatively thick transition zone at IF-MW2 compared to OB-MW1 may be related to withdrawal-induced mixing of the freshwater and the brackish water in the transition zone, because of the presence of five nearby production wells within $600 \mathrm{ft}$ of IF-MW2. At OB-MW1, where only one adjacent production well is within $600 \mathrm{ft}$, the water column in the well may be less affected by withdrawal-induced mixing.

\section{Central Saipan}

In the Kagman Peninsula, salinity profiles from the three monitor wells (KG-MW1, KG-MW2, and KG-MW3, see fig. 7) indicated spatially variable hydrologic conditions. At KG-MW3, the freshwater-lens thickness was 19-21 ft and the midpoint of the transition zone was about 29-33 ft below NMVD03. The salinity profile from KG-MW3 had high specific-conductance values close to those of saltwater (about $50,000 \mu \mathrm{S} / \mathrm{cm}$ ) near the bottom of the well, indicating that KG-MW3 penetrates through the freshwater lens and transition zone (fig. 22H). At KG-MW1 and KG-MW2 (figs. 22I and 22J), which extend about 113 and $95 \mathrm{ft}$ below sea level, respectively, only freshwater was encountered. The presence of only freshwater in KG-MW1 and KG-MW2, in addition to the relatively high water levels (table 3), indicated that confined groundwater may exist adjacent to these wells, likely within the Tagpochau Limestone, consistent with hydrogeologic descriptions by Van Der Brug (1985) and Hoffmann and others (1998) for the west side of Kagman Peninsula. Here, the low-permeability Donni formation of Weary and Burton (2011) likely overlies the Tagpochau Limestone, dipping gently to the east, and may impede the seaward movement of freshwater and cause the buildup of freshwater within the Tagpochau Limestone (Hoffmann and others, 1998). Because KG-MW1 and KG-MW2 may be in a confinedgroundwater setting and because the top of the transition zone $(1,400 \mu \mathrm{S} / \mathrm{cm})$ was not encountered in salinity profiles, the thickness of the freshwater lens was not estimated at these monitor wells (table 3).

Figure 23 (page 43). Map of freshwater-lens thickness estimates for monitor wells during July-August 2018; median chloride concentrations at municipal production wells during 2009-19; mean groundwater-withdrawal rates at municipal production wells during 2014-19; and selected faults in southern Saipan, Commonwealth of the Northern Mariana Islands. Median chloride concentrations and mean groundwater-withdrawal rates were derived from data provided by Commonwealth Utilities Corporation (at the time of publication, the data had not been published by the Commonwealth Utilities Corporation). Selected faults from Weary and Burton (2011). 


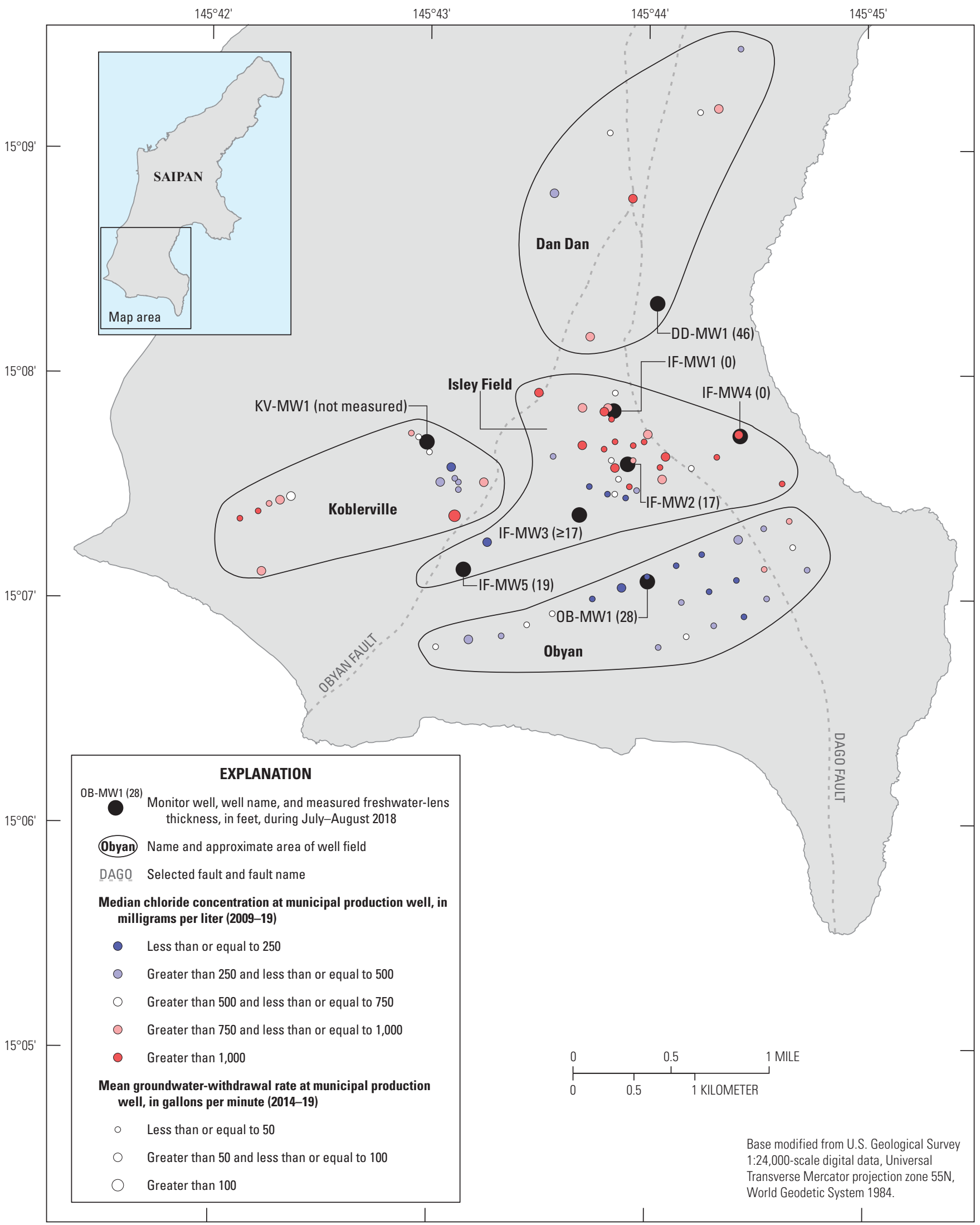


At ST-MW1 in the west-central area of the island, the freshwater-lens thickness was about $2 \mathrm{ft}$ in August 2018 and March 2019 (fig. 22K). A thicker freshwater lens was expected at ST-MW1 because discrete water-level measurements at ST-MW1 were greater than all but one (IF-MW3) of the waterlevel measurements at the remaining 9 monitor wells within the freshwater-lens system in July-August 2018 and March 2019, excluding KG-MW1 and KG-MW2, which may be in a confined-groundwater setting (table 3). Salinity profiles from ST-MW1, however, showed several step-like changes in specific conductance with depth that are commonly associated with borehole flow (see for example Rotzoll, 2010). Consequently, the freshwater-lens thickness and altitudes of the top and midpoint of the transition zone at ST-MW1 may not be representative of conditions in the adjacent aquifer.

\section{Northern Saipan}

At AM-MW1b, the only monitor well in the northern third of the island, salinity profiles indicated about $8 \mathrm{ft}$ of freshwater (fig. 22L). The salinity profiles at AM-MW1b show a slight step-like change in specific conductance between about 5-10 ft below NMVD03, indicative of possible borehole flow within this depth range. Despite possible borehole flow near the top of the water column, the measured altitude of the midpoint of the transition zone, about 34-35 ft below NMVD03, may be less affected by borehole flow.

\section{Estimated Altitudes of the Midpoint of the Transition Zone from the Ghyben-Herzberg Principle}

For each water-level measurement in a monitor well penetrating the freshwater-lens system during 2018-19 (all wells in table 3 except KG-MW1 and KG-MW2), the altitude of the midpoint of the transition zone was estimated using the Ghyben-Herzberg principle (table 3 ). The altitude of the midpoint of the transition zone was estimated by multiplying the water level, in ft relative to NMVD03, by -40 . In all profiles, the measured altitude of the midpoint of the transition zone was above (that is, shallower in the well than) the altitude estimated using the Ghyben-Herzberg principle (table 3). Differences between the measured and estimated altitudes of the midpoint may be attributed to the Ghyben-Herzberg principle's assumption of horizontal groundwater flow. In areas with substantial upward or downward groundwater flow, the Ghyben-Herzberg relation can underestimate or overestimate the altitude of the midpoint, respectively.

Another potential cause for discrepancy between the measured and estimated altitude of the midpoint of the transition zone is non-tidal sea-level changes. Non-tidal sea-level changes, occurring over weeks to years, are transmitted through the freshwater-lens system and influence groundwater levels (see for example fig. 12) — an increase in sea level generally causes the water table and the freshwater lens to shift upward, relative to the established vertical datum (for example, NMVD03). The Ghyben-Herzberg principle describes the hydrostatic balance of freshwater relative to sea level, however, not a static vertical datum. If the mean sea level at the time of a water-level measurement is greater than the sea level used to define the vertical datum, the measured water level, expressed relative to the vertical datum, may be greater than the Ghyben-Herzberg-relevant water level (that is, the distance between the water table and the current mean sea level), causing the Ghyben-Herzberg principle to overestimate the depth of the midpoint.

Additional possible causes for differences between the measured and estimated altitude of the midpoint of the transition zone include the effects of nearby groundwater withdrawals, aquifer heterogeneity, and tide-induced mixing of freshwater and saltwater.

\section{Seasonal Variability}

Rainfall recorded at Saipan International Airport during the 2018 dry season (December 2017-June 2018) was about 8 percent below average and rainfall recorded during the 2018 wet season (July-November 2018) was about 2 percent above average; average rainfall was determined for the period of 1954-2018 (fig. 24). During the four months preceding the salinity-profile measurements in March 2019 (November 2018-February 2019), recorded rainfall was about 64 percent below average.

Compared with freshwater-lens thicknesses in JulyAugust 2018, the freshwater-lens thicknesses in March 2019 were $4 \mathrm{ft}$ greater at OB-MW1, $2 \mathrm{ft}$ greater at KG-MW3, and the same at IF-MW2, ST-MW1, and AM-MW1b. The seasonal variability in the freshwater-lens thickness could not be determined for the remaining monitor wells. Compared with measured altitudes of the midpoint of the transition zone in July-August 2018, measured altitudes in March 2019 were 1-7 ft lower in five monitor wells (OB-MW1, IF-MW2, IF-MW4, KG-MW3, and ST-MW1), and $1 \mathrm{ft}$ higher in AM-MW1b.

The altitudes of the top and midpoint of the transition zone determined for March 2019 likely do not represent typical conditions at the end of the wet season (July to November) because (1) the salinity profiles were collected more than three months after the end of the 2018 wet season, and (2) monthly rainfall was below average in the four months preceding March 2019 (fig. 24). Salinity profiles collected in December after a wet season with near-average rainfall likely would result in more representative wet-season estimates of the freshwater-lens thickness. 


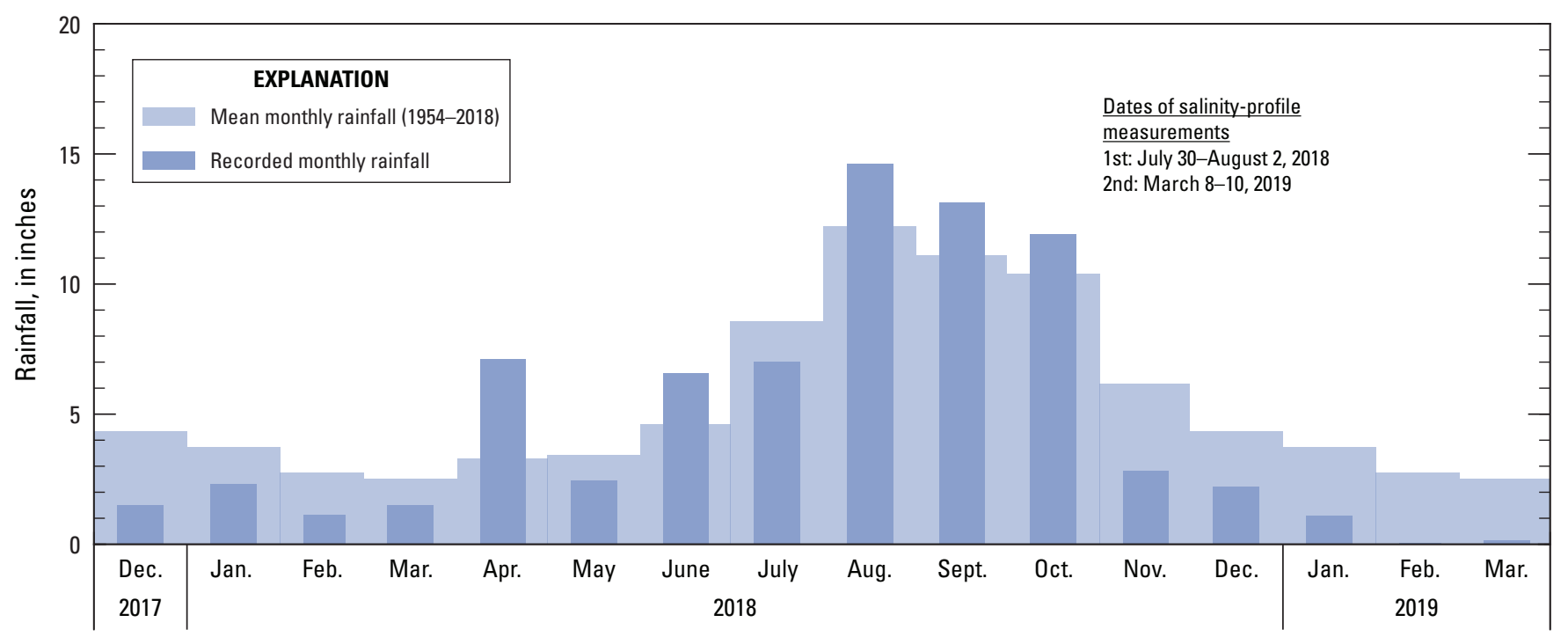

Figure 24. Graph of mean monthly rainfall and recorded monthly rainfall at Saipan International Airport during December 2017 to March 2019, Saipan, Commonwealth of the Northern Mariana Islands. Data from Lander (2004) and National Oceanic and Atmospheric Administration (2019).

\section{Future Study and Additional Data Collection}

Routine collection of groundwater data using consistent and reliable methods will facilitate prudent management of Saipan's groundwater resources. Specifically, (1) continued monitoring and recording of groundwater withdrawals is useful, and (2) continued collection of water samples from production wells and analyses for chloride concentration and specific conductance is desirable.

The current water-sample-collection frequency (semiannually) for each production well, while adequate for evaluating trends in chloride concentrations over several years, may be too infrequent for evaluating shorter-duration trends caused by changes in recharge and groundwater withdrawals. The semi-annual chloride-concentration samples could be supplemented with quarterly or monthly specific-conductance measurements at selected production wells because (1) specific-conductance measurements are less expensive than chloride-concentration analyses, and (2) the chloride concentration of each specific-conductance measurement could be estimated using an empirical relation (see for example fig. 21). Furthermore, if withdrawal rates from selected wells will be changed, then the collection frequency of chloride-concentration samples and specific-conductance measurements could temporarily be increased at the selected and nearby wells immediately before and for a few weeks after withdrawal rates are changed. Afterwards, the specificconductance and chloride-concentration measurements could be evaluated to assess the impacts of the withdrawal changes on groundwater conditions.

Evaluations of Saipan's groundwater resources are limited by the quality and availability of groundwater data.
Groundwater data collected with appropriate quality-assurance practices, reviewed for accuracy, and archived in a consistent manner to ensure retrieval maximizes the value and utility of the data and allows resource managers to monitor the effectiveness of the groundwater-management program.

Continuous water-level measurements have not been collected at any monitor well on Saipan since 2005. Continuous water-level measurements are useful for monitoring changes in the groundwater level over time and improving understanding of the hydrogeology, which is important for groundwater management. They also are fundamental inputs to numerical groundwater models, which can be used to predict changes in groundwater salinity and water levels in response to future changes in withdrawals (see for example Gingerich, 2013) and forecasted changes in rainfall and recharge. For example, on Guam, continuous water-level measurements currently are collected by the USGS at seven monitor wells in the northern Guam lens aquifer, near areas of high groundwater withdrawals, and have been used as inputs for several studies (see for example Jocson and others, 2002; Gingerich, 2013; and Rotzoll and others, 2013).

Salinity profiles, which show the vertical distribution of groundwater specific conductance in an aquifer, may reveal saltwater intrusion that is not detected by monitoring the chloride concentrations (or specific conductance) of groundwater withdrawals (see for example Meyer and Presley, 2001); although in very thin freshwater lenses, indicators of saltwater intrusion should also be apparent in the chloride concentrations of pumped water. Routinely collected salinity profiles may be evaluated to assess interannual and longer-term changes in Saipan's freshwater-lens system.

Several of the wells in Saipan's monitor-well network have deteriorated since they were constructed and can be rehabilitated so that groundwater data can be collected from 
them. The four obstructed boreholes (DD-MW1, IF-MW1, IF-MW3, and KV-MW1) can be cleared at low cost relative to drilling new wells; additionally, the wells could be lined with a screened casing to prevent additional material from the sides of the borehole from falling into the borehole and becoming obstructions. The Dan Dan and Koblerville well fields, representing about 19 percent of the municipal groundwater withdrawals on Saipan during 2018, currently have no usable monitor wells in which groundwater data can be collected. To address this lack of monitoring capability, obstructions in the existing monitor wells (DD-MW1 and KV-MW1) in the well fields can be dislodged or new monitor wells can be constructed. Additionally, the measuring-point altitude of the monitor wells where data are being collected should be surveyed to benchmarks that are referenced to the most recent common vertical datum, currently NMVD03, so that groundwater data from the network of monitor wells can be compared and used to accurately evaluate Saipan's groundwater conditions. If water-level data or other altitude-related data are collected at production wells, the production wells also should be surveyed to the same vertical datum. Furthermore, if the monitor wells and production wells are surveyed to a reliable and common vertical datum, a synoptic water-level survey could be conducted to provide a snapshot of hydrologic conditions and to help evaluate the directions of groundwater flow.

After a few years of collecting groundwater data, including continuous water-level measurements and periodic salinity profiles, these data could be used to construct a numerical groundwater model for either the whole island or for important groundwater areas, such as the southern plateau. Numerical groundwater models are a fundamental tool in groundwater hydrology and one constructed for Saipan could be used to (1) improve the basic understanding of the freshwater-lens system; (2) answer questions about past hydrologic observations; (3) simulate changes in water levels, the chloride concentrations of groundwater withdrawals, and salinity in the aquifer in response to forecasted or hypothetical changes in groundwater withdrawals, recharge, and land use (see for example Gingerich, 2013); and (4) help Saipan manage its groundwater resources in an efficient manner. Additional data that would improve the accuracy of a groundwater model for Saipan include (1) spatially distributed recharge estimates, which require considerable data, including rainfall, evapotranspiration, runoff, land-cover, and soil data; (2) geophysical data defining the contact between volcanic rocks and limestone; and (3) data characterizing the effects of faults on groundwater flow. The spatial distribution of recharge could be estimated by developing an island-wide water-budget model.

\section{Summary and Conclusions}

Nearly all the municipal water supply on Saipan is pumped from groundwater. Most of Saipan's available fresh groundwater is in a freshwater lens floating on top of saltwater, separated by a brackish-water transition zone. The freshwater, brackish water, and saltwater are all part of the freshwater-lens system. The thickness of the freshwater lens primarily is controlled by rock permeability and recharge, but also fluctuates in response to short- and long-term changes in groundwater withdrawals. Owing to the high permeability of the limestone formations that contain most of the freshwater lens, the freshwater lens is relatively thin (a few tens of feet) and the availability of fresh groundwater mainly is limited by salinity.

Records of monthly groundwater withdrawals from municipal production wells were available for May 2014March 2019, and during that period withdrawals ranged from 5.7 to 12.8 million gallons per day and averaged $9.3 \mathrm{Mgal} / \mathrm{d}$, although records were unavailable for 9 months (May 2015January 2016). About 47 percent of municipal groundwater withdrawals during May 2014-March 2019 were from production wells within the three southernmost well fields (Isley Field, Koblerville, and Obyan), and about 13 percent were from production wells within the Kagman well field on the Kagman Peninsula. Private wells, located mainly on the western coastal plain, are permitted to withdraw a total of about $7 \mathrm{Mgal} / \mathrm{d}$ of groundwater. Actual groundwater withdrawals from private wells, however, are uncertain because withdrawal records for private wells are not available.

The chloride concentrations of municipal groundwater withdrawals from 146 production wells was determined by the Commonwealth Utilities Corporation (CUC) about twice a year during December 2009-February 2019; a few of these wells are no longer in use. About 78 percent of the municipal production wells had median chloride concentrations greater than 250 milligrams per liter $(\mathrm{mg} / \mathrm{L})$, the maximum contaminant level for drinking water recommended as a secondary (non-enforceable) standard by the U.S. Environmental Protection Agency. The annual mean volume-weighted chloride concentration for groundwater from municipal production wells was $648 \mathrm{mg} / \mathrm{L}$ in 2017 and 781 in 2018, the only two years during 2009-19 with complete records of groundwaterwithdrawal and chloride-concentration data; the mean volumeweighted chloride concentration for groundwater withdrawals during September-October 1998 was $984 \mathrm{mg} / \mathrm{L}$. The chloride concentrations of groundwater withdrawals from private wells generally exceeded $1,000 \mathrm{mg} / \mathrm{L}$ during 2009-16. Consequently, many of the private wells used to supply drinking water are operated in combination with a reverse-osmosis system to reduce salinity of the water.

Municipal production wells in well fields developed in high-level aquifers (Akgak, Capitol Hill, and Donni Spring) are in the center of the island and these wells had the lowest median chloride concentrations on Saipan, between 24 and $42 \mathrm{mg} / \mathrm{L}$. The remaining production wells withdraw water from the freshwater-lens system and had median chloride concentrations that varied spatially and ranged from 93 to $3,083 \mathrm{mg} / \mathrm{L}$. The median chloride concentration of all water samples collected from production wells in the Obyan, Koblerville, and Isley Field well fields during 2009-19 was $384 \mathrm{mg} / \mathrm{L}, 746 \mathrm{mg} / \mathrm{L}$, and $990 \mathrm{mg} / \mathrm{L}$, respectively. The median chloride concentration of water samples collected 
from production wells in the Kagman well field, located on the Kagman Peninsula, was $401 \mathrm{mg} / \mathrm{L}$. The median chloride concentration of water samples collected from production wells in the Sablan Quarry well field, located in west-central Saipan, was $384 \mathrm{mg} / \mathrm{L}$. Groundwater withdrawals from production wells in the Marpi Quarry well field, the only well field in the northern part of the island, had a median chloride concentration of about $1,600 \mathrm{mg} / \mathrm{L}$.

The Mann-Kendall test was used to determine if chloride concentrations of groundwater withdrawals at 146 municipal wells had statistically significant upward or downward trends during December 2009-February 2019. Trends were considered statistically significant for probability values (p-values) less than or equal to 0.05 . The test results indicate upward trends at 9 wells, downward trends at 52 wells, and no trend at 85 wells. The three well fields (Isley Field, Koblerville, and Obyan) with the greatest groundwater withdrawals during May 2014-March 2019 contain 33 wells with downward trends, one well with an upward trend, and 39 wells with no trends. The Kagman well field had the greatest number of production wells (4) with upward trends.

Vertical salinity profiles were collected at 12 monitor wells on Saipan during 2018-19; six of these wells extend through the transition zone of the freshwater-lens system. The salinity profiles show the vertical distribution of specific conductance in a well and were used to determine the altitudes of the top and the midpoint of the transition zone. The altitude of the midpoint of the transition zone was determined in seven monitor wells and ranged from $52 \mathrm{ft}$ below NMVD03 at a monitor well in the Dan Dan well field (DD-MW1) to $23 \mathrm{ft}$ below NMVD03 at a monitor well in Isley Field well field (IF-MW4).

The salinity profiles also were used to determine the thickness of the freshwater lens, computed for each monitor well and salinity profile as the distance between the altitudes of the water table and the top of the transition zone. The thickness of the freshwater lens was greatest (46 ft) in a monitor well in the Dan Dan well field (DD-MW1) near the northern part of the southern plateau. Freshwater-lens thickness estimates elsewhere were (1) between 0 and $32 \mathrm{ft}$ for remaining monitor wells on the southern plateau, (2) between 19 and $21 \mathrm{ft}$ for a monitor well on the Kagman Peninsula (KG-MW3), (3) $2 \mathrm{ft}$ for a monitor well in the Sablan Quarry well field on west-central Saipan (ST-MW1), and (4) $8 \mathrm{ft}$ for a monitor well in the Marpi Quarry well field on northern Saipan (AM-MW1b).

The seasonal variability of the freshwater-lens system was assessed by collecting salinity profiles twice: JulyAugust 2018 and March 2019. Compared with freshwaterlens thicknesses in July-August 2018, the freshwater-lens thicknesses in March 2019 were $4 \mathrm{ft}$ greater at OB-MW1, 2 $\mathrm{ft}$ greater at KG-MW3, and the same at IF-MW2, ST-MW1, and AM-MW1b. Compared with measured altitudes of the midpoint of the transition zone in July-August 2018, measured altitudes in March 2019 were 1-7 ft lower in five monitor wells (OB-MW1, IF-MW2, IF-MW4, KG-MW3, and ST-MW1), and $1 \mathrm{ft}$ higher in AM-MW1b. The altitudes of the top and midpoint of the transition zone determined for March 2019 likely do not represent typical conditions at the end of the wet season (July to November) because (1) the salinity profiles were collected more than three months after the end of the 2018 wet season, and (2) monthly rainfall was below average in the four months preceding March 2019.

Effective management of the groundwater resources in Saipan depends on the availability of high-quality groundwater data, which have value beyond their immediate use for a specific study. Groundwater data collected continuously or routinely over several years would help in evaluating how Saipan's groundwater resources respond to hydrologic stresses, including the locations and rates of groundwater withdrawals, changes in land use, and recharge. Frequent evaluations of Saipan's groundwater resources can help water-resource managers assess the effectiveness of management decisions. A numerical groundwater model could be created for Saipan to help managers develop strategies that might be needed to face future challenges caused by changes to groundwater withdrawals and rainfall.

\section{References Cited}

Ayers, J.F., 1981, Evaluation of the groundwater resources of the Agag Basin, Saipan: University of Guam, Technical Report No. 31, 82 p.

Badon Ghyben, W., 1889, Notes on the probable results of the proposed well drilling near Amsterdam: Tijdschrift van het Konirklijk Instituut van Ingenieurs, 1888-89, The Hague, p. 21.

Bakalowicz, Michel, 2005, Karst groundwater; a challenge for new resources: Hydrogeology Journal, v. 13, p. 148-160.

Barlow, P.M., 2003, Ground water in freshwater-saltwater environments of the Atlantic coast: U.S. Geological Survey Circular 1262, 113 p., accessed May 30, 2019, at https:// pubs.usgs.gov/circ/2003/circ1262/.

Barlow, P.M., and Reichard, E.G., 2010, Saltwater intrusion in coastal regions of North America: Hydrogeology Journal, v. 18, p. 247-260. [Also available at https://doi.org/10.1007/ s10040-009-0514-3]

Bear, J; Cheng, A.H.-D.; Sorek, S; Ouazar, D; and Herrera, I, eds., 1999, Seawater intrusion in coastal aquifers-concepts, methods, and practices: Dordrecht, Netherlands, Kluwer Academic Publishers, 625 p.

Budd, D.A., and Vacher, H.L., 1991, Predicting the thickness of fresh-water lenses in carbonate paleo-islands: Journal of Sedimentary Petrology, v. 61, no. 1., p. 43-53. [Also available at https://doi.org/10.1306/D4267681-2B26-11D78648000102C1865D] 
Caldwell, P.C., Merrifield, M.A., and Thompson, P.R., 2015, Sea level measured by tide gauges from global oceans the joint archive for sea level holdings (NCEI Accession 0019568): NOAA National Centers for Environmental Information, Dataset, accessed March 19, 2019, at https:// doi.org/10.7289/V5V40S7W.

Carlson, E; Doyle, D; and Smith, D, 2009, Development of comprehensive geodetic vertical datums for the United States Pacific Territories of American Samoa, Guam, and the Northern Marianas: Surveying and Land Information Science, v. 69, no. 1, p. 5-17.

Carruth, R.L., 2000, Summary of hydrologic data for 1998, Saipan, Commonwealth of the Northern Mariana Islands: U.S. Geological Survey Open-File Report 00-301, 39 p., accessed October 29, 2018, at https://doi.org/10.3133/ ofr00301.

Carruth, R.L., 2003, Ground-water resources of Saipan, Commonwealth of the Northern Mariana Islands: U.S. Geological Survey Water-Resources Investigations Report 03-4178, 3 Plates, accessed May 24, 2019, at https://pubs.usgs.gov/ wri/wri034178/.

Cloud, P.E., Jr., Schmidt, R.G., and Burke, H.W., 1956, Geology of Saipan, Mariana Islands, Part 1, General geology: U.S. Geological Survey Professional Paper 280-A, 126 p. [Also available at https://pubs.er.usgs.gov/ publication/pp280A]

Cooper, H.H., Jr., 1959, A hypothesis concerning the dynamic balance of fresh water and salt water in a coastal aquifer: Journal of Geophysical Research, v. 64., no. 4, p. 461-467. [Also available at https://doi.org/10.1029/ JZ064i004p00461]

Cosca, M.A., Arculus, R.J., Pearce, J.A., and Mitchell, J.G., 1998, 40Ar/39Ar and K-Ar geochronological age constraints for the inception and early evolution of the IzuBonin-Mariana arc system: The Island Arc, v. 7, p. 579-595. [Also available at https://doi.org/10.1111/ j.1440-1738.1998.00211.x]

CNMI Department of Commerce, 2017, Population Characteristics, Commonwealth of the Northern Mariana Islands: CNMI Department of Commerce, Central Statistics Division, 4th Quarter, 2017, p. 76.

Davis, D.A., 1959, Water resources, in Military geology of Saipan, Mariana Islands: Chief of Engineers, U.S. Army, v. 2,96 p.

Dreybrodt, W., 1990, The role of dissolution kinetics in the development of karst aquifers in limestone; a model simulation of karst evolution: The Journal of Geology, v. 98, no. 5., p. 639-655. [Also available at https://doi. org/10.1086/629431]
Fratesi, B., 2013, Hydrology and geochemistry of the freshwater lens in coastal karst, in Lace, M.J., and Mylroie, J.E., eds., Coastal karst landforms: Coastal Research Library 5, p. 59-75.

Gingerich, S.B., 2013, The effects of withdrawals and drought on groundwater availability in the Northern Guam Lens Aquifer, Guam: U.S. Geological Survey Scientific Investigations Report 2013-5216, 76 p., https://doi.org/10.3133/ sir20135216.

Gingerich, S.B., and Engott, J.A., 2012, Groundwater availability in the Lahaina District, west Maui, Hawai'i: U.S. Geological Survey Scientific Investigations Report 20125010, 90 p., accessed June 3, 2019, at http://pubs.usgs.gov/ sir/2012/5010/.

Helsel, D.R., and Hirsch, R.M., 2002. Statistical methods in water resources: U.S. Geological Survey Techniques of Water-Resources Investigations, book 4, chap. A3, 510 p.

Helsel, D.R., Mueller, D.K., and Slack, J.R., 2005, Computer program for the Kendall family of trend tests: U.S. Geological Survey Scientific Investigations Report 2005-5275, 4 p.

Hem, J.D., 1985, Study and interpretation of the chemical characteristics of natural water ( $3 \mathrm{~d}$ ed.): U.S. Geological Survey Water-Supply Paper 2254, 263 p.

Herzberg, Alexander, 1901, The water supply on parts of the North Sea coast: Munich, Journal Gasbeleuchtenug and Wasserversorgung, v. 44, p 815-819, 842-844.

Hoffmann, J.P., Carruth, R.L., and Meyer, William, 1998, Geology, ground-water occurrence, and estimated well yields from the Mariana Limestone, Kagman Area, Saipan, Commonwealth of the Northern Mariana Islands: U.S. Geological Survey Water-Resources Investigations Report 98-4077, 38 p., https://doi.org/10.3133/wri984077.

Izuka, S.K., and Ewart, C.J., III, 1995, Geology, streamflow, and water chemistry of the Talufofo Stream Basin, Saipan, Northern Mariana Islands: U.S. Geological Survey WaterResources Investigations Report 95-4183, 26 p., https://doi. org/10.3133/wri954183.

Izuka, S.K., and Gingerich, S.B., 1998, Estimation of the depth to the fresh-water/salt-water interface from vertical head gradients in wells in coastal aquifers and island aquifers: Hydrogeology Journal, v. 6, p. 365-373.

Izuka, S.K., 1999, Hydrogeologic interpretations from available ground-water data, Tutuila, American Samoa: U.S. Geological Survey Water-Resources Investigations Report 99-4064, 2 plates, https://doi.org/10.3133/wri994064.

Jakovovic, D; Werner, A.D.; de Louw, P.G.B.; Post, V.E.A.; and Morgan, L.K., 2016, Saltwater upconing zone of influence: Advances in Water Resources, v. 94, p. 75-86. 
Jenson, J.W., Keel, T.M., Mylroie, J.R., Mylroie, J.E., Stafford, K.W., Taboroši, Danko, and Wexel, Curt, 2006, Karst of the Mariana Islands; the interaction of tectonics, glacioeustasy, and freshwater/seawater mixing in island carbonates: Geological Society of America Special Paper 404, p. $129-138$.

Jocson, J.M.U., Jenson, J.W., and Contractor, D.N., 2002, Recharge and aquifer response; Northern Guam Lens Aquifer, Guam, Mariana Islands: Journal of Hydrology, v. 260 , p. $231-254$.

Johnson, A.G., 2012, A water-budget model and estimates of groundwater recharge for Guam: U.S. Geological Survey Scientific Investigations Report 2012-5028, 53 p., http:// pubs.usgs.gov/sir/2012/5028/.

Karig, D.E., 1971, Structural history of the Mariana island arc system: Geological Society of America Bulletin, v. 82, p. 323-344.

Kestin, T.S., Karoly, D.J., Yano, J.-I., and Rayner, N.A., 1998, Time-frequency variability of ENSO and stochastic simulations: Journal of Climate, v. 11, p. 2258-2272.

Kim, K.-Y., O’Brien, J.J., and Barcilon, A.I., 2003, The principal physical modes of variability over the tropical Pacific: Earth Interactions, v. 7, no. 3, 32 p.

Knapp, M.A., Geeraert, N., Kim, K., and Knee, K.L., 2020, Submarine groundwater discharge (SGD) to coastal waters of Saipan (Commonwealth of the Northern Mariana Islands, USA) - implications for nitrogen sources, transport and ecological effects: Water, v. 12, no. 11, 32 p., https://www. mdpi.com/2073-4441/12/11/3029\#cite.

Lander, M.A., 2004, Rainfall climatology for Saipan; distribution, return-periods, El Niño, tropical cyclones, and long-term variations: Mangilao, University of Guam, Water and Environmental Research Institute of the Western Pacific Technical Report no. 103, 54 p.

Liu, K.S., Chan, J.C.L., 2008, Interdecadal variability of western North Pacific cyclone tracks: Journal of Climate, v. 21., p. 4464-4476.

Mair, A., Hagedorn, B., Tillery, S., El-Kadi, A.I., Westenbroek, S., Ha, K., and Koh, G.W., 2013, Temporal and spatial variability of groundwater recharge on Jeju Island, Korea: Journal of Hydrology, v. 501, p. 213-226.

Maloszewski, P., Stichler, W., Zuber, A., and Rank, D., 2002, Identifying the flow systems in a karstic-fissuredporous aquifer, the Schneealpe, Austria, by modelling of environmental ${ }^{18} \mathrm{O}$ and ${ }^{3} \mathrm{H}$ isotopes: Journal of Hydrology, v. 256, no. $1-2$, p. $48-59$.

Mather, J.D., 1975, Development of the groundwater resources of small limestone islands: Quarterly Journal of Engineering Geology, v. 8, p. 141-150.
Meijer, A., Reagan, M., Ellis, H., Shafiqullah, M., Sutter, J., Damon, P., and Kling, S., 1983, Chronology of volcanic events in the eastern Philippine Sea in Hayes, D.E. (ed.), The tectonic and geologic evolution of southeast Asian seas and islands; Part 2: Washington, D.C., American Geophysical Union, Geophysical Monograph 27, p. 349-359.

Meyer, W., and Presley, T.K., 2001, The response of the Iao Aquifer to ground-water development, rainfall, and landuse practices between 1940 and 1998, Island of Maui, Hawaii: U.S. Geological Survey Water-Resources Investigations Report 00-4223, 60 p., https://doi.org/10.3133/ wri20004223.

Mink, J.F., 1987, Hydrological characterization of the groundwater resources, island of Saipan: Report to the Division of Environmental Quality, Department of Public Health and Environmental Services, Commonwealth of the Northern Mariana Islands, $59 \mathrm{p}$.

Mylroie, J.E., and Carew, J.L., 1990, The flank margin model for dissolution cave development in carbonate platforms: Earth Surface Processes and Landforms, v. 15, no. 5, p. 413-424.

Mylroie, J.L., Jenson, J.W., Jocson, J.M.U., and Lander, M.A., 1999, Karst geology and hydrology of Guam; a preliminary report: University of Guam, Water and Environmental Research Institute of the Western Pacific Technical Report no. $89,32 \mathrm{p}$.

Mylroie, J.E., and Vacher, H.L., 1999, A conceptual view of carbonate island karst, in Karst Modeling Symposium, 5th, Charlottesville, Va., February 24-27, 1999, Proceedings: Charlottesville, Va., Karst Waters Institute, p. 48-57.

Mylroie, J.E., Jenson, J.W., Taborosi, D., Jocson, J.M.U., Vann, D.T., and Wexel, C., 2001, Karst features of Guam in terms of a general model of carbonate island karst: Journal of Cave and Karst Studies, v. 63, p. 9-22.

Mylroie, J.R., and Mylroie, J.E., 2007, Development of the carbonate island karst model: Journal of Cave and Karst Studies, v. 69, no. 1, p. 59-75.

Nance, T., 1983, Status and future development of Saipan's water supply: Belt, Collins \& Associates, Honolulu, Hawai'i, 106 p.

National Oceanic and Atmospheric Administration, 2019, Climate Data Online: NOAA National Centers for Environmental Information, accessed April 15, 2019, at https:// www.ncdc.noaa.gov/cdo-web/.

Oki, D.S., 2005, Numerical simulation of the effects of lowpermeability valley-fill barriers and the redistribution of ground-water withdrawals in the Pearl Harbor Area, Oahu, Hawaii: U.S. Geological Survey Scientific Investigations Report 2005-5253, 111 p., https://doi.org/10.3133/ sir20055253. 
Oki, D.S., 2006, Numerical simulation of the hydrologic effects of redistributed and additional ground-water withdrawal, Island of Molokai, Hawaii: U.S. Geological Survey Scientific Investigations Report 2006-5177, 49 p., https:// doi.org/10.3133/sir20065177.

Paillet, F.L., Williams, J.H., Oki, D.S., and Knutson, K.D., 2002, Comparison of formation and fluid-column logs in a heterogeneous basal aquifer: Ground Water, v. 40, no. 6, p. $577-585$.

Perrault, J.A., 2007, Reconnaissance study of the hydrology of American Memorial Park, Island of Saipan, Commonwealth of the Northern Mariana Islands: U.S. Geological Survey Scientific Investigations Report 2007-5042, 31 p., http:// pubs.usgs.gov/sir/2007/5042/.

Reagan, M.K., Hanan, B.B., Heizler, M.T., Hartman, B.S., and Hickey-Vargas, R., 2008, Petrogenesis of volcanic rocks from Saipan and Rota, Mariana Islands, and implications for the evolution of nascent island arcs: Journal of Petrology, v. 49 , no. 3, p. 441-464.

Reilly, T.E., and Goodman, A.S., 1987, Analysis of saltwater upconing beneath a pumping well: Journal of Hydrology, v. 89 , no. 3-4, p. 169-204.

Ropelewski, C.F., and Halpert, M.S., 1987, Global and regional scale precipitation patterns associated with the El Niño/Southern Oscillation: Monthly Weather Review, v. 115, p. $1606-1626$.

Ropelewski, C.F., and Jones, P.D., 1987, An extension of the Tahiti-Darwin Southern Oscillation Index: Monthly Weather Review, v. 115, p. 2161-2165.

Rotzoll, Kolja, 2010, Effects of groundwater withdrawal on borehole flow and salinity measured in deep monitor wells in Hawai' $i$-implications for groundwater management: U.S. Geological Survey Scientific Investigations Report 2010-5058, 42 p., accessed at https://doi.org/10.3133/ $\operatorname{sir} 20105058$.

Rotzoll, Kolja, 2012, Numerical simulation of flow in deep open boreholes in a coastal freshwater lens, Pearl Harbor Aquifer, O`ahu, Hawai ${ }^{`} i$ : U.S. Geological Survey Scientific Investigations Report 2012-5009, 39 p., http://pubs.usgs. gov/sir/2012/5009/.

Rotzoll, K., Gingerich, S.B., Jenson, J.W., and El-Kadi, A.I., 2013, Estimating hydraulic properties from tidal attenuation in the Northern Guam Lens Aquifer, territory of Guam, USA: Hydrogeology Journal, v. 21, no. 3, p. 643-654.

Schneider, J.C., and Kruse, S.E., 2003, A comparison of controls on freshwater lens morphology of small carbonate and siliciclastic islands; examples from barrier islands in Florida, USA: Journal of Hydrology, v. 284, no. 1-4, p. 253-269.
Stern, R.J., Fouch, M.J., and Klemperer, S.L., 2003, An overview of the Izu-Bonin-Mariana subduction factory: American Geophysical Union, Geophysical Monograph, v. 138, p. 175-222.

Teutsch, Georg; and Sauter, Martin, 1991, Groundwater modeling in karst terranes; scale effects, data acquisition and field effects, in Conference on Hydrogeology, Ecology, Monitoring, and Management of Ground Water Karst Terranes, 3rd, Nashville, Tenn., December 4-6, 1991, Proceedings: Nashville, Tenn., Ground Water Management, p. 17-35.

Todd, R., Cloud, P.E., Jr., Low, D., and Schmidt, R.G., 1954, Probable occurrence of Oligocene on Saipan: American Journal of Science, v. 252, p. 673-682.

Townley, L.R., 1995, The response of aquifers to periodic forcing: Advances in Water Resources, v. 18, no. 3., p. 125-146.

Trenberth, K.E., 1984, Signal versus noise in the Southern Oscillation: Monthly Weather Review, v. 112, no. 2, p. 326-332.

Trenberth, K.E., 1997, The definition of El Niño: Bulletin of the American Meteorological Society, v. 78, no. 12, p. 2,271-2,778.

Trenberth, K.E., and Hurrell, J.W., 1994, Decadal atmosphereocean variations in the Pacific: Climate Dynamics, v. 9, p. 303-319.

Underwood, M.R., Peterson, F.L., and Voss, C.I., 1992, Groundwater lens dynamics of atoll islands: Water Resources Research, v. 28, no. 11, p. 2,889-2,902.

U.S. Environmental Protection Agency (USEPA), 2018, 2018 edition of drinking water standards and health advisories: EPA 822-F-18-001, Office of Water, 12 p.

U.S. Geological Survey, 2019, USGS water data for the nation: U.S. Geological Survey National Water Information System Web, accessed July 29, 2019, at https://dx.doi.org/10.5066/ F7P55KJN.

Vacher, H.L., and Mylroie, J.E., 2002, Eogenetic karst from the perspective of an equivalent porous medium: Carbonates and Evaporites, v. 17, no. 2, p. 182-196.

Van Der Brug, O., 1985, Compilation of water resources development and hydrologic data of Saipan, Mariana Islands: U.S. Geological Survey Water-Resources Investigations Report 84-4121, 578 p., https://doi.org/10.3133/ wri844121.

Van Der Brug, O., 1986, The 1983 drought in the Western Pacific: U.S. Geological Survey, Open-File Report 85-418, 89 p., https://doi.org/10.3133/ofr85418. 
Visher, F.N., and Mink, J.F., 1964, Ground-water resources in southern Oahu, Hawaii: U.S. Geological Survey WaterSupply Paper, 1778. 133 p.

Weary, D.J., and Burton, W.C., 2011, Preliminary geologic map of the island of Saipan, Commonwealth of the Northern Mariana Islands: U.S. Geological Survey Open-File Report 2011-1234, scale 1:25,000, 1 sheet, https://doi. org/10.3133/ofr20111234.

Wentworth, C.K., 1942, Storage consequences of the GhybenHerzberg theory: Transactions of the American Geophysical Union, p. 683-693.

Werner, A.D., Alcoe, D.W., Ordens, C.M., Hutson, J.L., Ward, J.D., and Simmons, C.T., 2011, Current practice and future challenges in coastal aquifer management; flux-based and trigger-level approaches with application to an Australian case study: Water Resource Management, v. 25, p. 1831-1853.
Werner, A.D., Bakker, M.; Post, V.E.A., Vandenbohede, A., Lu, C., Ataie-Ashtiani, B., Simmons, C.T., and Barry, D.A., 2013, Seawater intrusion processes, investigation, and management - recent advances and future challenges: Advances in Water Resources, v. 51, p. 3-26.

Whitaker, F.F., and Smart, P.L., 2000, Characterising scaledependence of hydraulic conductivity in carbonates; evidence from the Bahamas: Journal of Geochemical Exploration, v. 69-70, p. 133-137.

White, W.B., 2002, Karst hydrology—recent developments and open questions: Engineering Geology, v. 65, no. 2-3, p. 85-105.

White, I., and Falkland, T., 2010, Management of freshwater lenses on small Pacific islands: Hydrogeology Journal, v. 18, p. 227-246.

Yumoto, M., and Matsuura, T., 2001, Interdecadal variability of tropical cyclone activity in the western North Pacific: Journal of the Meteorological Society of Japan, v. 79, no. 1, p. 23-35. 
Moffett Field Publishing Service Center, California

Manuscript approved for publication November 9, 2020

Edited by Aditya Navale

Illustration support by Katie Sullivan

Layout and design by Kimber Petersen 
